\title{
The Role of PI3K p110 $\gamma$ in chronic liver injury
}

\author{
Dissertation
}

ZUR ERLANGUNG DES DOKTORGRADES DER NATURWISSENSCHAFTEN (DR.RER.NAT.) DER FAKULTÄT BIOLOGIE UND VORKLINISCHE MEDIZIN DER UNIVERSITÄT REGENSBURG

\author{
vorgelegt von \\ Karin Dostert \\ aus Regensburg \\ 2011
}


Promotionsgesuch eingereicht am 05.07.2011

Die Arbeit wurde angeleitet von: Prof. Dr. Claus Hellerbrand

Unterschrift:

(Karin Dostert) 
für

Rainer Dostert

...Ich gehe nicht weg.

Hab' meine Frist verlängert.

Neue Zeitreise, offene Welt.

Habe Dich sicher, in meiner Seele. Ich trag' Dich bei mir, bis der Vorhang fällt. 


\section{Table of Contents}

$\begin{array}{lr}\text { Summary } & 8\end{array}$

$\begin{array}{ll}\text { I. Introduction } & 10\end{array}$

$\begin{array}{ll}\text { I.1. Liver diseases } & 10\end{array}$

$\begin{array}{ll}\text { I.1.1. Liver fibrosis } & 10\end{array}$

I.1.2. Etiological factors for chronic liver disease 11

$\begin{array}{ll}\text { I.1.2.1. Viral hepatitis } & 11\end{array}$

$\begin{array}{ll}\text { I.1.2.2. Alcoholic steatohepatitis (ASH) } & 11\end{array}$

I.1.3. Non-alcoholic fatty liver disease (NAFLD) 12

$\begin{array}{ll}\text { I.1.3.1. Definition } & 12\end{array}$

$\begin{array}{ll}\text { I.1.3.2. Prevalence } & 12\end{array}$

$\begin{array}{ll}\text { I.1.3.3. Pathogenesis } & 13\end{array}$

$\begin{array}{ll}\text { I.2. Hepatic stellate cells (HSC) } & 13\end{array}$

I.3. Phosphatidyl-insitol-3-kinase (PI3K) 15

$\begin{array}{ll}\text { I.4. Experimental models for chronic liver disease } & 18\end{array}$

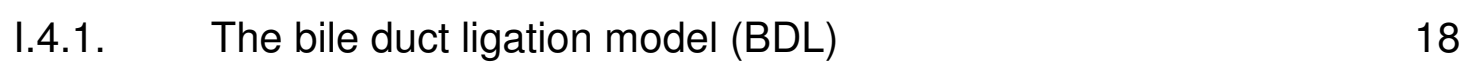

I.4.2. Models for non-alcoholic steatohepatitis (NASH) 19

I.5. Aim of the thesis 20

II. Materials and Methods 21

II.1. Materials 21

II.1.1. Cells 21

II.1.2. Animals 21

II.1.3. Primers 22

II.1.4. Buffers and Solutions 23

II.1.5. Chemicals and Reagents 24

II.1.6. Laboratory expendables 25

II.1.7. Laboratory instruments 26

II.2. Methods 28

II.2.1. Cell culture (in vitro experiments) 28

II.2.1.1. Isolation of primary hepatic stellate cells 28 
II.2.1.2. Cultivation of cell lines 28

II.2.1.3. Determination of cell number and viability 29

II.2.1.4. Oleic acid preparation 29

II.2.1.5. Tests with cells and cell supernatant 30

II.2.2. Genotyping 31

II.2.3. Animal models 32

II.2.3.1. Bile duct ligation 33

II.2.3.2. NASH model 33

II.2.4. Serum analysis $\quad 34$

II.2.5. Histology and Immunohistochemistry 34

II.2.5.1. Haematoxylin/ Eosin staining 34

II.2.5.2. Sirius red staining (Collagen stain) 35

II.2.5.3. Immunohistochemistry for $\alpha \mathrm{SMA}$, HNE and caspase 3

II.2.5.4. Sudan III staining (Lipid stain) 36

II.2.5.5. TUNEL assay (TdT-mediated dUTP-biotin nick end labelling) 36

II.2.5.6. Quantification of positive labeled areas 36

II.2.6. Quantification of hepatic Free fatty acids (FFA) and Triglyceride (TG) content $\quad 37$

II.2.7. Quantification of mRNA expression 37

II.2.7.1. Isolation of RNA 37

II.2.7.2. Reverse Transcription (RT-PCR) 38

II.2.7.3. Quantitative real time polymerase chain reaction (PCR) 39

II.2.8. Western blotting 41

II.2.8.1. Isolation of proteins 41

II.2.8.2. Analysis of Protein concentration (BCA assay) 41

II.2.8.3. SDS polyacrylamid gel electrophoresis (SDS-PAGE) 42

II.2.8.4. Protein transfer 43

II.2.8.5. Protein detection 43

$\begin{array}{lll}\text { II.2.9. Statistics } & 45\end{array}$ 
III. Results

III.1. Analysis of PI3K p110 $\gamma$ expression in diseased murine and human liver tissue

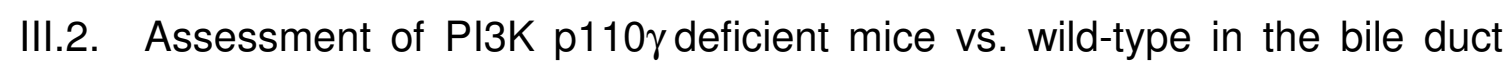
ligation model

III.2.1. Body weight and liver/ body weight ratio

III.2.2. General liver histology (Haematoxylin/Eosin staining)

III.2.3. Serum transaminases and levels of bilirubin and alkaline phosphatase

III.2.4. mRNA expression of markers of hepatic inflammation 51

III.2.5. Expression of markers of HSC activation and hepatic fibrosis 52 III.2.5.1. mRNA expression of markers of HSC activation and hepatic fibrosis 52

III.2.5.2. Protein expression of Collagen I

III.2.5.3. Histological evaluation of fibrosis and HSC activation

III.3. Assessment of PI3K p110 $\gamma$ deficient mice vs. wild-type in a dietary NASH model

III.3.1. Body weight and liver/ body weight ratio 56

III.3.2. Serum Transaminases and LDH 57

III.3.3. mRNA expression of markers of hepatic inflammation 57

III.3.4. Expression of markers for HSC activation and fibrosis 58

III.3.4.1. mRNA expression of profibrogenic markers 58

III.3.4.2. Protein expression of collagen $\quad 59$

III.3.4.3. Histological evaluation of fibrosis and HSC activation 60

III.4. Search for mechanisms causing the opposing effects of PI3K p110 deficiency on hepatic fibrosis in the BDL and NASH model 62

III.4.1. Hepatocyte apoptosis 62

III.4.2. Hepatic Steatosis and oxidative stress 64

III.4.2.1. Histological evaluation of fatty degeneration 64

III.4.2.2. Intra-hepatic lipid content 65

III.4.2.3. Oxidative stress 66

III.5. Analysis of the mechanisms causing the enhanced hepatic lipid accumulation in PI3K p110. deficient mice in the dietary NASH model 
III.5.1. De novo lipogenesis $\quad 69$

III.5.2. Fatty acid (FA) import and transport 70

$\begin{array}{lll}\text { III.5.3. FFA combustion } & 72\end{array}$

III.5.4. Triglyceride (TG) synthesis $\quad 74$

III.6. Analysis of mechanisms causing the increased hepatic import and combustion of FFA PI3K p110 $\gamma$ deficient mice 76

$\begin{array}{lll}\text { III.6.1. Insulin level and signaling } & 76\end{array}$

$\begin{array}{lll}\text { III.6.2. } & \text { Adiponectin level and signaling } & 78\end{array}$

III.7. PI3K p110 in hepatic stellate cells (HSC) 81

III.7.1. PI3K p110 $\gamma$ expression during activation of HSC 81

III.7.2. $\quad$ PI3K p110 $\gamma$ expression in FFA stimulated HSC 81

III.7.2.1. Dose-response of HSC-B to Oleic acid 82

III.7.2.2. Time course of IL-8 mRNA expression in response to Oleic acid 83

III.7.2.3. Signaling via p70 S6K after oleic acid stimulation 83

III.7.2.4. II-8 secretion from HSC after blocking of complete PI3K 84

$\begin{array}{ll}\text { IV. Discussion } & 85\end{array}$

$\begin{array}{ll}\text { V. References } & 89\end{array}$

$\begin{array}{ll}\text { VI. Appendix } & 102\end{array}$

$\begin{array}{ll}\text { VI.1. Abbreviations } & 102\end{array}$

VI.2. Bisherige Präsentation der Daten dieser Arbeit 107

VI.3. Danksagung 108

VI.4. Eidesstattliche Erklärung 110 


\section{Summary}

The Phosphatidyl-insitol-3-kinase (PI3K) is a central mediator in many signalling pathways, e.g. in insulin signalling and in proinflammatory signalling via mTOR. Previous studies suggested a critical role of PI3K signalling during hepatic fibrogenesis, however, the role of different PI3K p110 isoforms has not been discriminated.

The aim of this project was to assess the expression and function of PI3K p110 $\gamma$ in chronic liver disease with a focus on hepatic fibrosis.

We found that the expression of the PI3K class $1 \mathrm{~B}$ unit $\mathrm{p} 110 \gamma$ is increased in the liver during chronic injury. Further, we found that $110 \gamma$ expression is enhanced during the activation of hepatic stellate cells (HSC), a process which plays a key role in hepatic fibrosis. We further discovered that PI3K p110 $\gamma$ deficiency had divergent effects on the activation of HSC and hepatic fibrosis, respectively, in two different models for chronic liver injury.

The bile duct ligation model (BDL) causes chronic injury by inducing hepatocyte apoptosis/necrosis, because of high hepatic concentrations of bile acids. Proinflammatory mediators lead to the activation of resident liver macrophages (i.e. Kupffer cells) and infiltrating immune cells. PI3K p110 $\gamma$ deficient mice revealed significantly diminished liver fibrosis compared to wild-type (WT) mice.

In a second model for chronic liver injury, a dietary model for non-alcoholic steatohepatitis $(\mathrm{NASH}), \mathrm{PI} 3 \mathrm{~K}$ p110 $\gamma$ deficiency surprisingly had no protective effect, but even aggravated liver injury. NASH is primarily caused by a dysregulation of fatty acid (FFA) metabolism, which leads to hepatic lipid accumulation. Free fatty acids then lead to the generation of reactive oxygen species (ROS) and subsequently to lipid peroxidation, which causes hepatic inflammation and fibrosis.

Here, we found that PI3K p110 $\gamma$ deficiency significantly enhanced hepatic FFA accumulation and ROS formation. As potential underlying cause for the enhanced FFA accumulation in the PI3K p110 $\gamma$ deficient mice we identified impaired FFA transport and enhanced $\beta$-oxidation.

In conclusion, we provide experimental evidence that the effect of PI3K p110 varies significantly, depending on the cause of liver injury. Particularly, in a model of NAFLD PI3K p110 $\gamma$ seems to inhibit hepatic steatosis, inflammation and 
fibrogenesis. Currently, PI3K p110 $\gamma$ inhibitors are under clinical development for the treatment of inflammatory disorders and cardiovascular dysfunctions. Based on the data of the present study one has to be very cautious regarding harmful effects of a PI3K p110 $\gamma$ inhibition in patients with the metabolic syndrome or known fatty liver disease, respectively. 


\section{Introduction}

\section{I.1. Liver diseases}

There exist several reasons for acute liver injury like intoxication with drugs or alcohol or viral infections, which can lead to severe liver injury. As the liver has a high regenerative potential acute injury rarely leads to liver failure. The major problem is when liver diseases get chronic and lead to a permanent injury of the liver by inducing chronic hepatic inflammation and subsequently liver fibrosis. This permanent remodelling of the liver can lead to cirrhosis and complete liver failure.

\section{I.1.1. Liver fibrosis}

The extracellular matrix (ECM), which guarantees structural (and functional) integrity of the hepatic parenchyma, consists mainly of collagens, elastins and proteoglycans. In the healthy liver the ECM comprises less than 3\% of the relative area on liver tissue sections (Geerts, 2001), whereas in liver fibrosis the percentage of ECM rises significantly. Liver fibrosis can be considered as a wound-healing response characterized by excessively enhanced deposition of ECM proteins, which eventually cause organ dysfunction (Bataller and Brenner, 2005). Additionally, the composition of ECM changes after liver injury. In the fibrotic liver ECM is mainly composed of fibrillar collagens (I and III) and fibronectin, whereas the normal matrix is mainly composed of collagens IV and VI (Gressner, 1995). These changes in quantity and quality cause impaired liver function, because the flow of plasma between the sinusoidal lumen and the hepatocytes is impaired (Hernandez-Gea and Friedman, 2011). In chronic liver injury the intra-hepatic accumulation and alteration of ECM is mainly triggered by liver inflammation and can be caused either by an overproduction of ECM proteins, a deficiency in ECM degradation or by a combination of both. 


\section{I.1.2. Etiological factors for chronic liver disease}

\section{I.1.2.1. Viral hepatitis}

Currently, five different forms of the hepatitis virus are known (Hepatitis A-E). The first three are the most relevant while the others have a rather low incidence. Hepatitis $A$ and $B$ have been extensively studied and there exists a vaccine against both. The Hepatitis $A$ virus does not play a role regarding liver fibrosis because infections with this virus do not become chronic.

Hepatitis B can take a chronic course in about $5 \%$ of cases (Elgouhari et al., 2008), and chronic infection has an approximately $30 \%$ probability to progress to liver cirrhosis.

The worldwide seroprevalence of hepatitis $\mathrm{C}$ virus $(\mathrm{HCV})$ antibodies is estimated to be $3 \%$ with marked geographic variations from $1 \%$ in North America to $10 \%$ in North Africa (Wasley and Alter, 2000). Consequently, this disease is one of the most frequent liver diseases in the world. One of the main problems is that until now there exists no vaccine against this virus. In a significant number of cases the HCV virus persists in the liver and causes chronic inflammation leading to liver fibrosis, cirrhosis and liver cancer.

\section{I.1.2.2. Alcoholic steatohepatitis (ASH)}

Chronic alcohol consumption is one of the main etiological factors for chronic liver disease worldwide (Barve et al., 2008), as the liver is the site of alcohol metabolism. However, only a fraction of drinkers develop significant hepatic inflammation and even less progress to hepatic fibrosis and cirrhosis. Still, alcoholic liver disease (ALD) is one of the most common reasons for liver transplantation in Europe and the United States (Adachi and Brenner, 2005, Bellentani et al., 1994).

Alcohol is predominantly metabolized in hepatocytes, which also accumulate dietary lipids, rendering interactions between alcohol- and lipid-metabolism very likely. It has been known quite a while that ethanol stimulates hepatic fatty acid synthesis (Lieber and Schmidt, 1961). During the oxidation of ethanol to acetaldehyde NAD is reduced to NADH, which promotes fatty acid synthesis while 
counteracting lipid catabolism and consequently leads to fat accumulation in hepatocytes (Galli et al., 1999,Lieber and Schmidt, 1961). Even moderate alcohol consumption can thus promote the development of hepatic steatosis, which predisposes to fibrosis and cirrhosis, but is reversible trough abstinence (Teli et al., 1995).

\section{I.1.3. Non-alcoholic fatty liver disease (NAFLD)}

\section{I.1.3.1. Definition}

The term NAFLD summarizes a range of hepatic diseases from hepatic steatosis without inflammation to hepatic steatosis plus inflammation and fibrosis (nonalcoholic steatohepatitis; NASH). The first clinical cases of NASH were described in 1980 (Ludwig et al., 1980). The phenotype of NASH includes histomorphological changes like macrovesicular steatosis, pericellular fibrosis, ballooning of hepatocytes and inflammatory cell foci (Contos and Sanyal, 2002), and in this steps resembles the changes seen in alcoholic liver disease (ASH).

\section{I.1.3.2. Prevalence}

Over the last 20 years it has become evident that the metabolic syndrome, which is characterized by hypertriglyceridemia, hypertension, obesity and insulin resistance (Rector et al., 2008), can lead to non-alcoholic fatty liver disease (NAFLD) and non-alcoholic steatohepatitis (NASH) respectively. Due to the increase of patients with the metabolic syndrome NAFLD has become the most common cause for chronic liver diseases in industrialised countries (Clark et al., 2002). Here, the prevalence of NAFLD is estimated between $20 \%$ and $30 \%$ (Browning et al., 2004,Ruhl and Everhart, 2004). NASH has a worldwide prevalence of $5 \%$ to $10 \%$, but there are large geographic differences concerning the percentage of cases (Reid, 2001,Younossi et al., 2002). In many patients also $\mathrm{NASH}$ stays asymptomatic and is only discovered during examination of an 
unrelated medical problem (Powell et al., 1990). However, up to $80 \%$ of NASH patients develop liver fibrosis and 16\% develop cirrhosis (Reid, 2001).

\section{I.1.3.3. Pathogenesis}

In the late nineties Day and James presented their "two-hit" hypothesis for the pathogenesis of NASH (Day and James, 1998), the "first hit" being the hepatic lipid accumulation, which is caused by a dysregulation of fatty acid metabolism. The liver is then sensitized to a "second hit", which is an additional pathogenic insult and causes hepatic inflammation by enhanced cytokine production and promotion of oxidative stress. Known factors that can contribute to the progression of liver steatosis to NASH are hepatic inflammation, gut derived endotoxin, nutritional deficiencies or drugs that contribute to oxidative stress by generation of reactive oxygen species (ROS) (Clouston and Powell, 2002). NASH can also be caused by a combination of different factors so that the development of NASH is determined by an interaction of environmental and genetic factors (Day, 2002).

\section{I.2. Hepatic stellate cells (HSC)}

In the progression of liver fibrosis and this way also NASH hepatic stellate cells (HSC) play a crucial role, because this cell population is the main manufacturer of ECM proteins in the liver (Reeves and Friedman, 2002). HSC were first described in 1876 by von Kupffer (Wake, 1971) and are today known to be the central mediators of hepatic fibrosis in chronic liver disease (Bataller and Brenner, 2005,Friedman, 2008b). HSC reside in the subendothelial space (Disse) between the hepatocytes and the sinusoidal endothelial cells, having intimate contact to both cell populations to facilitate intercellular transport of cytokines and other soluble markers (Friedman, 2008a).

In chronic liver injury HSC are activated by so-called pro-fibrogenic stimuli, which are mainly cytokines and growth factors that are secreted by neighboring cells like hepatocytes, thrombocytes and Kupffer cells (Maher, 2001). But also reactive oxygen species (ROS) and lipid peroxides stimulate HSC to become fibrogenic 
(Galli et al., 2005), as well as Fas-mediated apoptosis of hepatocytes. This first step is called initiation and leads to changes in HSC phenotype as well as in gene expression. Upon activation HSCs transform from a quiescent cell type, which stores vitamin $\mathrm{A}$, to an activated myofibroblast, which expresses $\alpha$-smooth muscle actin (asma) and starts to proliferate (Friedman, 2000,Geerts et al., 1991,Ramadori et al., 1990). At the same time, activated HSC acquire proinflammatory and fibrogenic properties (Friedman, 2008a). This is the second step, the perpetuation of HSC activation. In this state HSC proliferate and migrate to the site of tissue damage, where they accumulate and start to secrete a large variety of ECM proteins, leading to the build up of fibrous scar tissue (Figure 1).

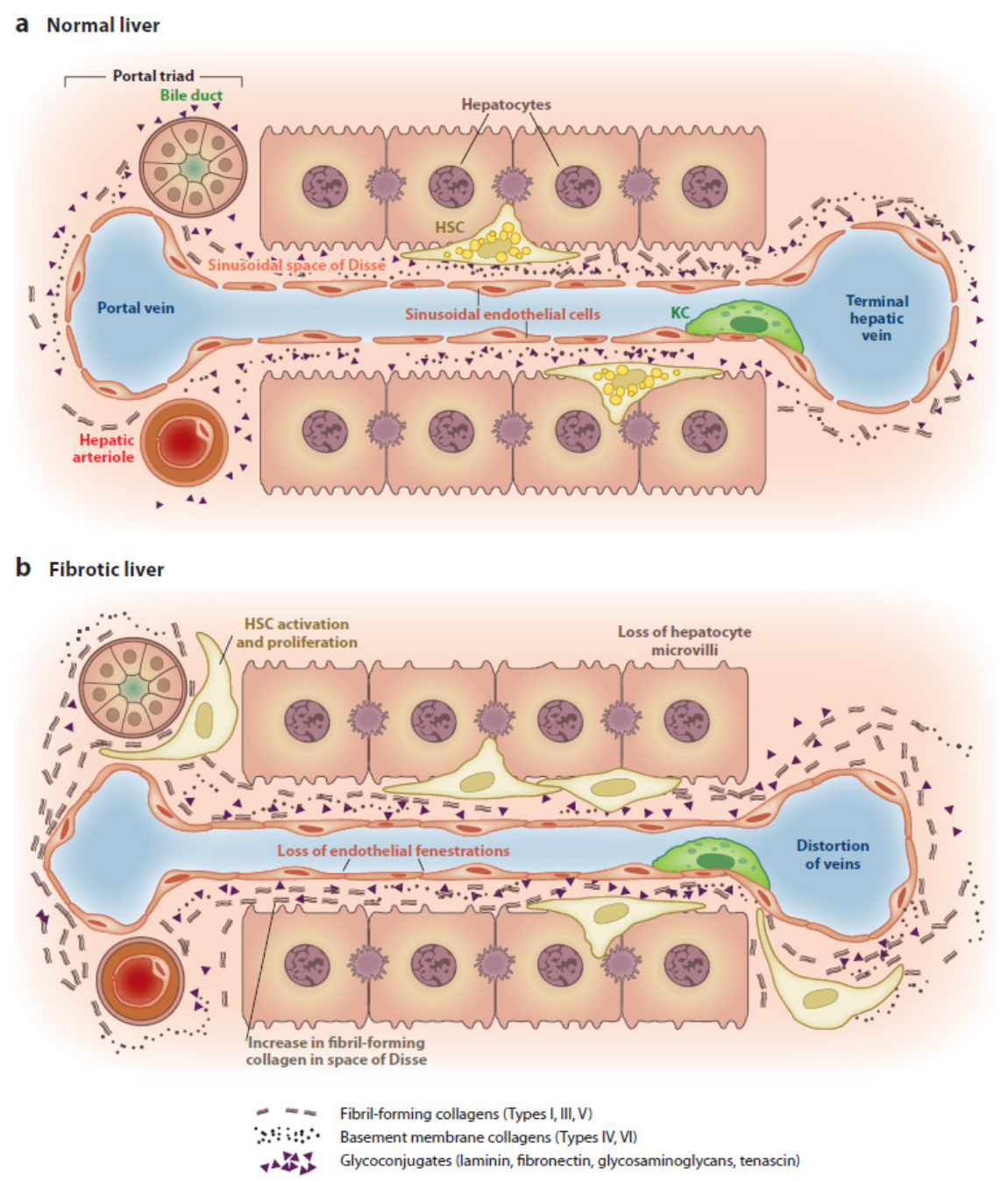

Figure 1: (a) healthy liver with quiescent HSC (b) In chronic liver injury the activation of Kupffer cells and thrombocytes leads to paracrine HSC activation and subsequently to the accumulation of ECM as well as an alteration of ECM composition. The hepatic function deteriorates due to hepatocyte apoptosis, loss of sinusoidal endothelial fenestrae and distortion of hepatic veins.

Figure by Hernandez-Gea and Friedman. (Hernandez-Gea and Friedman, 2011) 
The predominant ECM protein in activated HSC is collagen type I. Its production is regulated transcriptionally by enhancing mRNA expression and posttranscriptionally by increasing collagen I mRNA stability (Lindquist et al., 2004,Stefanovic et al., 1999). At the same time the expression of tissue inhibitor of matrix metalloproteinases 1 (TIMP-1) is upregulated in activated HSC (Benyon and Arthur, 2001). As TIMPs inhibit matrix metalloproteinases (MMPs), which are responsible for the degradation of fibrous tissue, activated HSC also contribute to the imbalance of fibrogenesis and fibrolysis in chronic liver injury by inhibiting ECM degradation. The most potent stimulus for collagen I expression in activated HSC is the transforming growth factor $\beta$ (TGF $\beta$ ) (Poli, 2000), which is produced by HSC (autocrine) but is also derived from paracrine sources (Kupffer cells, sinusoidal epithelial cells) (Ghiassi-Nejad and Friedman, 2008,Inagaki and Okazaki, 2007).

Activated HSC are characterized by enhanced pro-inflammatory gene expression, including monocyte chemoattractant protein 1 (MCP-1) (Marra et al., 1993), which contributes to hepatic inflammation by recruiting activated lymphocytes and monocytes. Several cytokines, like TNF and INF $\gamma$, are known to induce the secretion of leukocyte chemoattractants and expression of adhesion markers in HSC (Maher, 2001). Additionally, activated HSC highly express TLR4 and respond to LPS treatment with enhanced responsiveness to TGF $\beta$ and elevated inflammatory response (Paik et al., 2003,Seki et al., 2007). This way activated HSC also contribute to hepatic inflammation.

The next and last step is called resolution and occurs, if liver injury subsides, leading to HSC apoptosis or reversion to a quiescent phenotype (Ghiassi-Nejad and Friedman, 2008).

\section{I.3. Phosphatidyl-insitol-3-kinase (PI3K)}

Phosphatidyl-insitol-3-kinase (PI3K) is a central mediator in many signaling pathways, e.g. in insulin signaling (Alessi and Downes, 1998) and in proinflammatory signaling via mTOR (Hay and Sonenberg, 2004). PI3K is a heterodimeric lipid and protein-kinase, which consists of a regulatory $(85 \mathrm{kD})$ and a catalytic subunit $(110 \mathrm{kD})$. The PI3K family can be divided into three subclasses. Class I is subdivided into class IA and IB. Class IA consists of a regulatory subunit $(p 85 \alpha, p 85 \beta)$ and a catalytic subunit $(p 110 \alpha, p 110 \beta, p 110 \delta)$ and is activated by 
receptor tyrosine kinases (e.g. PDGF receptor, insulin receptor) whereas class IB is activated by $G$ protein-coupled receptors (e.g. chemokine receptors) and consists of p101 (regulatory subunit) and $\mathrm{p} 110 \gamma$ (catalytic subunit) (reviewed by (Gunzl and Schabbauer, 2008).

After PI3K activation several second messenger phoshoinositol lipids (PIPs) are generated providing a link to intracellular downstream signaling, which is important in cell differentiation, proliferation, immunity, apoptosis and growth (Katso et al., 2001). IA and IB classes of PI3K can be inhibited by phosphatase and tensin homologue (PTEN), a lipid phosphatase, which dephosphorylates PIP3 to PIP2 (Chalhoub and Baker, 2009). Downstream of PI3K a serin-threonine kinase (AKT/PKB) is activated, which in turn regulates several cellular processes by activation or inhibition of downstream proteins. The mammalian target of rapamycin (mTOR) is activated by AKT and subsequently activates the ribosomal p70 S6 kinase (p70S6K), which stimulates protein synthesis and cell growth (Hay and Sonenberg, 2004). Besides, AKT stimulates proliferation by inhibiting glycogen synthase kinase 3 (GSK3) and cell survival by inhibiting pro-apoptotic proteins (e.g. mammalian forkhead members of the class O1 (FoxO1)) (Burgering and Medema, 2003,Liang and Slingerland, 2003) (Figure 2). 


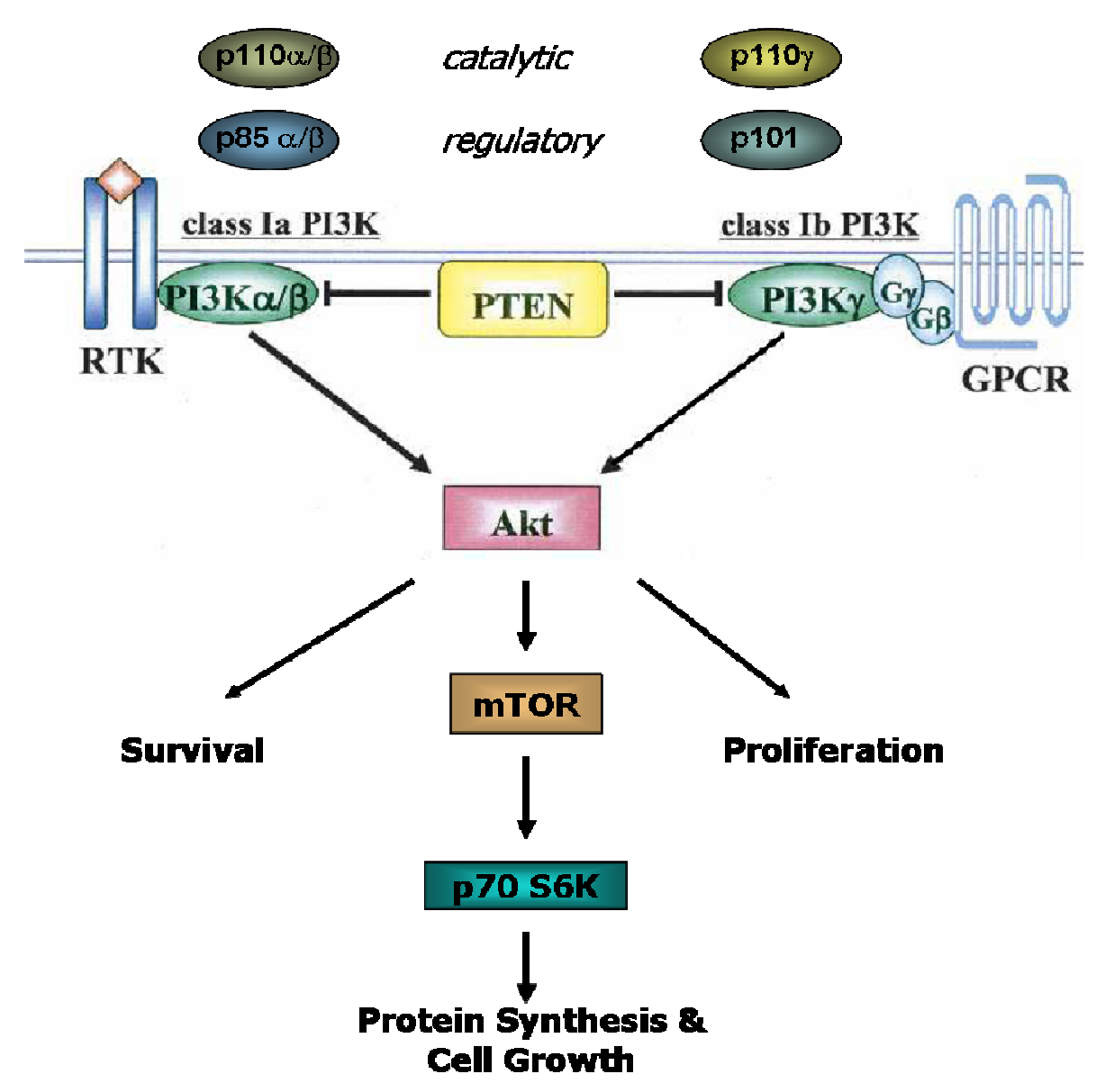

Figure 2: PI3K signaling pathway: Different subclasses of PI3K each consisting of a regulatory and catalytic subunit are activated by a specific kind of receptor. Class IA PI3K is activated by receptor tyrosine kinases (RTK), class IB by G protein-coupled receptors (GPCR). Several cellular processes like proliferation, protein synthesis and cell survival are regulated via downstream activation of AKT. Based on a Figure by Shiojima and Walsh (Shiojima and Walsh, 2006).

We are just beginning to understand the distribution and roles of different PI3K isoforms in the liver. PI3K isoforms $\mathrm{p} 110 \alpha$ and $\mathrm{p} 110 \beta$ are expressed ubiquitously. PI3K p110 $\gamma$ has mainly been described in immune cells but has also been reported in hepatocytes (Hohenester et al., 2010,Misra et al., 2003). It has been reported that the cytoprotective effect of cAMP-GEF in hepatocytes is associated with PI3K p110 $\alpha / p 110 \beta$ activation (Gates et al., 2009), and p110 $\alpha$ is known to be necessary for insulin signaling in the liver (Foukas et al., 2006). Further, Hohenester and colleagues revealed that PI3K p110 $\gamma$ contributes to bile-salt induced apoptosis in hepatocytes (Hohenester et al., 2010). In general, PI3K signaling is known to play a crucial role in glucose and lipid metabolisms. Most recent studies indicate a role of $p 110 \alpha$ in the development of fatty liver. Hepatic TG content was significantly decreased in liver-specific $p 110 \alpha$ knockout mice compared to $p 110 \alpha+/+$ mice, 
and $p 110 \alpha$ knockout prevented high-fat diet-induced liver steatosis, whereas p110ß knockout mice revealed neither under standard chow nor upon high fat diet alterations of hepatic lipid content (Chattopadhyay et al., 2011). However, liver glycogen content was reduced in both groups of knockout mice, and serum glucose and insulin were elevated in $\mathrm{p} 110 \beta$ knockout mice compared to controls. Further, PTEN deficient mice spontaneously developed significant hepatic steatosis at the age of 10 weeks, which further progresses with ballooning of hepatocytes, an inflammatory cell infiltrate and sinuosidal fibrosis with aging (Watanabe et al., 2005). Further, several studies have shown a role of PI3K in liver fibrosis. Blocking PI3K activity, using either pharmacological or genetic approaches, inhibits HSC proliferation and collagen expression through interruption of key downstream signaling pathways including Akt and p70 S6 Kinase (p70S6K) (Gabele et al., 2005,Gentilini et al., 2000,Reif et al., 2003). Further, adenoviral delivery of a dominant negative mutant of p85, which contains a mutant regulatory subunit that lacks the binding site for the $110-\mathrm{kDa}$ catalytic subunit of the enzyme, to HSC inhibits progression of hepatic fibrosis in mice following bile duct ligation (BDL) (Son et al., 2009).

\section{I.4. Experimental models for chronic liver disease}

\section{I.4.1. The bile duct ligation model (BDL)}

There are several ways to induce experimental hepatic fibrosis (reviewed by (Hayashi and Sakai, 2011). One of the most common used is the bile duct ligation (BDL) model, which induces cholestatic liver injury (Bataller et al., 2005) (Desmouliere et al., 1997,Tuchweber et al., 1996). The bile duct ligation model has already widely been used to evaluate genetic factors, which are associated with hepatic fibrogenesis. Experimental liver fibrogenesis is for example increased in IL-6 knockout mice, but decreased in TNF- and CD14 knockout mice (Ezure et al., 2000, Gabele et al., 2009, Isayama et al., 2006). 


\section{I.4.2. Models for non-alcoholic steatohepatitis (NASH)}

There exist several experimental animal models, which use genetic defects or targeted over-expression of specific genes to induce NASH by impairing hepatic lipid metabolism or inducing obesity in rodents (Anstee and Goldin, 2006).

One widely used model for NASH is the leptin-deficient ob/ob mouse, which develops obesity and diabetes but no significant liver injury. This is due to leptin deficiency, because leptin is essential for the hepatic fibrogenic response (Leclercq et al., 2002). Transgenic mice over-expressing SREBP-1 develop fatty liver spontaneously (Shimano et al., 1996) and PPAR $\alpha$ null mice show lipid accumulation in the liver after fasting or high fat diet (Kersten et al., 1999).

These models are sufficient to evaluate the specific role of certain factors in the development of liver disease in vivo, but lead only rarely to the pathophysiology of liver injury as seen in patients and thus might not reflect the natural etiology of the disease. There exist, however, also experimental models, which are not dependant on genetic defects and should be a better way to mimic NASH.

Another approach to induce NASH is to change nutrition to different diets like highfat and/or sucrose-rich diets (Surwit et al., 1995). However, in rodents these diets lead only to little expression of proinflammatory factors and minimal fat accumulation in the liver (Anstee and Goldin, 2006). The by far most often used nutritional model is the methionine-choline deficient diet (MCD) (Weltman et al., 1996). Feeding this diet leads to a rapid development of hepatic steatosis, inflammation and subsequent fibrosis (Koppe et al., 2004), because the secretion of very low density particles (VLDL) is impaired. This model does, however, not sufficiently mimic NASH as seen in patients. This diet deprives rodents of a vital amino acid rather than providing over-nutrition. So, instead of becoming obese, these animals rapidly loose weight (Kirsch et al., 2003,Romestaing et al., 2007).

In 2007 Matsuzawa et al. described another dietary model for NASH, which closely resembles human NASH (Matsuzawa et al., 2007). This model uses an atherogenic diet, the so-called Paigen-diet containing 15\% cocoa butter, 1.25\% cholesterol and $0.5 \%$ sodium cholate, which was originally created by Beverly Paigen to induce atherosclerosis in rodents (Paigen et al., 1985). This model appears as suitable model to study the development and progression of $\mathrm{NASH}$, because rodents, apart from atherosclerosis, were found to develop liver steatosis 
with subsequent hepatic inflammation and mild fibrosis (Dorn et al., 2010a,Dorn et al., 2010b,Jeong et al., 2005)

\section{I.5. Aim of the thesis}

The aim of this thesis was to assess the expression and function of PI3K p110 $\gamma$ in chronic liver disease, with a focus on liver fibrosis. The expression of PI3K p110 was analyzed in hepatic tissue specimens obtained from different experimental models as well as patients with chronic liver disease. Further, the BDL and a $\mathrm{NASH}$ model were applied to PI3K p110 $\gamma$ knockout mice and wild-type control mice. Moreover, the expression and function of $\mathrm{p} 110 \gamma$ was assessed in HSC. 


\section{Materials and Methods}

\section{II.1. Materials}

\section{II.1.1. Cells}

For the in vitro experiments an immortalized activated human HSC line (HSChTERT) generated by ectopic expression of hTERT (human telomerase reverse transcriptase) was used, which has been established and characterized by Schnabl et al. (Schnabl et al., 2002).

Additionally primary human or mouse HSCs were used (see II.2.).

\section{II.1.2. Animals}

Control animals (female C57BI/6) were purchased at Charles River Laboratories (Sulzfeld, Germany) at the age of 8 weeks.

Female PI3Kp110 $\gamma$ deficient mice, on a C57BI/6 background, backcrossed 10 times, lacking the catalytic subunit $\mathrm{p} 110 \gamma$, were obtained as a kind gift from Prof. J. Penninger (IMBA, Akademie der Wissenschaften, Vienna, Austria). These mice show a normal phenotype with slight deficiencies in T-cell development and activation as well as impaired thymocyte development and reduced macrophage, dendritic- and mast cell migration (Del Prete et al., 2004,Hirsch et al., 2000,Sasaki et al., 2000,Wymann et al., 2003).

All animals received human care in compliance with institutional guidelines and were housed under the same standard conditions, namely at room temperature $\left(22{ }^{\circ} \mathrm{C}\right)$ in a $12 \mathrm{~h}$ dark and light cycle. Food and water was accessible at all times. Mice were fed standard chow (Ssniff $\AA^{8}$ R/M-H Cat.\# V1534-0) or an NASH inducing diet (NASH model) which was also prepared by Ssniff (Soest, Germany) and contains $17 \%$ fat, supplemented with $1.25 \%$ cholesterol and $0.5 \%$ cholate, according to Matsuzawa et al. (Matsuzawa et al., 2007). 


\section{II.1.3. Primers}

Name

$18 s$

Acox-1

CD36

Collagen I

Cyp4A10

DGAT2

FABP

Fas

FASN

IL-8 (human)

LPL

MCP-1

Nox2

$\mathrm{p} 47^{\text {phox }}$

Pai-1

PI3K p110 $\gamma$

PI3K p110 $\gamma$ (human)

TGF $\beta$

TNF forward primer

reverse primer
AAA CGG CTA CCA CAT CCA AG

QIAGEN QuantiTect Primer Assay

QIAGEN QuantiTect Primer Assay

CGG GCA GGA CTT GGG TA

QIAGEN QuantiTect Primer Assay

QIAGEN QuantiTect Primer Assay

QIAGEN QuantiTect Primer Assay

QIAGEN QuantiTect Primer Assay

QIAGEN QuantiTect Primer Assay
TCT GCA GCT CTG TGT GAA GGT GCA GTT

QIAGEN QuantiTect Primer Assay

TGG GCC TGC TGT TCA CA

QIAGEN QuantiTect Primer Assay

QIAGEN QuantiTect Primer Assay

QIAGEN QuantiTect Primer Assay

QIAGEN QuantiTect Primer Assay

QIAGEN QuantiTect Primer Assay

QIAGEN QuantiTect Primer Assay

QIAGEN QuantiTect Primer Assay
CGG AAT CTG AAT GGT CTG ACT CGT TA

AAC CCT CTG CAC CCA GTT TTC CT

TCC GAT CCA GGT TTT TAA TGT A 
Lyophilized primers were either purchased at SIGMA Genosys (Hamburg, Germany) or as QuantiTect Primer Assays at Qiagen (Hilden, Germany). Primers were solved in $\mathrm{H}_{2} \mathrm{O}_{\text {dist. }}$ or TE buffer respectively and stored at $-20{ }^{\circ} \mathrm{C}$.

\section{II.1.4. Buffers and Solutions}

Sirius Red/ Fast Green solution (0.1\%) 100 mg Direct Red 80 (Sirius Red)

(Collagen stain)

$100 \mathrm{mg}$ Fast Green FCF

in $100 \mathrm{ml}$ Picric acid

Sudan III solution

$0,6 \mathrm{~g}$ Sudan III in

(Lipid stain)

$200 \mathrm{ml}$ Ethanol $70 \%$

boil up to clear the solution and filtrate

through folded filter

TBS(T)

$20 \mathrm{mM}$ Tris $\mathrm{pH} 7.5$

$150 \mathrm{mM} \mathrm{NaCl}$

$(0,1 \%$ Tween 20$)$

TE-buffer

$10 \mathrm{mM}$ Tris/HCl

1 mM EDTA pH 8.0

Cell Culture Medium

$4.5 \mathrm{~g} / \mathrm{l}$ Glucose

DMEM (high glucose/10\%FCS)

$300 \mu \mathrm{g} / \mathrm{ml}$ L-Glutamine

Supplemented with:

$10 \%(\mathrm{v} / \mathrm{v})$ FCS

$400 \mathrm{U} / \mathrm{ml}$ Penicillin

$50 \mu \mathrm{g} / \mathrm{ml}$ Streptomycin 


\section{II.1.5. Chemicals and Reagents}

Agarose SeaKem ${ }_{\circledast}$ LE

Bovine serum albumin (BSA)

Chloroform

DEPC

Direct Red 80 (Sirius Red)

DMEM medium

DMSO

Eosin

Ethanol

Fast Green FCF

Fatty acid free BSA

FCS (fetal calf serum)

Haematoxylin

Methanol

Milk powder

Oleic acid

PBS

Penicillin

Picric acid

Ponceau S

Roti®-Histol

Streptomycin

Sudan III
Biozym, Hess/Oldendorf, Germany

PAA Laboratories, Pasching, Austria

Merck, Darmstadt, Germany

Carl Roth $\mathrm{GmbH}$, Karlsruhe, Germany

SIGMA, Deisenhofen, Germany

PAA Laboratories, Cölbe, Germany

SIGMA, Deisenhofen, Germany

SIGMA, Deisenhofen, Germany

J.T. Baker, Deventer, The Netherlands

SIGMA, Deisenhofen, Germany

SIGMA, Hamburg, Germany

PAN-Biotech, Aidenbach, Germany

SIGMA, Deisenhofen, Germany

Merck, Darmstadt, Germany

Carl Roth, Karlsruhe, Germany

SIGMA, Deisenhofen, Germany

PAA Laboratories, Pasching, Austria

Invitrogen, Karlsruhe, Germany

SIGMA, Deisenhofen, Germany

SIGMA, Deisenhofen, Germany

Carl Roth $\mathrm{GmbH}$, Karlsruhe, Germany

Invitrogen, Karlsruhe, Germany

SIGMA, Deisenhofen, Germany 
TissueTek®

Triton X-114

Trypsin/EDTA

Tween $20 \AA$

$\beta$-Mercaptoethanol
SAKURA, Finetek, Zoeterwoude, Netherlands

SIGMA, Deisenhofen, Germany

PAA Laboratories, Cölbe, Germany

SIGMA, Deisenhofen, Germany

SIGMA, Deisenhofen, Germany

\section{II.1.6. Laboratory expendables} ABgene ${ }^{\circledR}$ PCR Plates (Thermo-Fast ${ }^{\circledR}$ Thermo Fisher Scientific, Karlsruhe,
Germany Germany

Cell culture flasks T25, T75, T125

Corning, New York, USA

CryoTube vials

Nunc, Roskilde, Denmark

ENDOSAFE tubes (borosilicate)

Charles River, Margate, Great-Britain

Falcon tubes (15 ml and $50 \mathrm{ml}$ )

Corning, New York, USA

Glassware (various)

Schott, Mainz, Germany

Impact 384 Tips (Pipette tips $30 \mu$ for Thermo Fisher Scientific, Karlsruhe, Matrix Pipette) Germany

Multi-well plates

Corning, New York, USA

Needles Microlance ${ }^{T M} 3$ (22G and 27G) Becton Dickinson, Madrid, Spain

Pipette Tips

Eppendorf, Hamburg, Germany

$(10,20,100$ und $1000 \mu l)$

Pipettes (stripettes $\circledast$ )

Corning, New York, USA

$(5,10,25,50 \mathrm{ml})$

Reaction vessels ( 1.5 and $2 \mathrm{ml}$ )

Eppendorf, Hamburg, Germany

Safe-Lock tubes Biopur®

Eppendorf, Hamburg, Germany

Scalpels (No. 11)

Pfm, Köln, Germany 
Strip tubes $(0.2 \mathrm{ml})$

Syringes Plastipak ${ }^{\mathrm{TM}}$ Luer $1 \mathrm{ml}$

\section{II.1.7. Laboratory instruments}

ABI PRISM® $7900 \mathrm{HT}$

Sequence detection system

Accu-jet $\circledast$ Pipette controller

ADVIA 1800 analyzer

Curix 60 automatic film developer

EMax® Microplate Reader

Eppendorf Centrifuge 5424

Eppendorf Pipettes (10-1000)

GeneAmp® PCR System 9700

Homogenisator MICCRA D-1

HS 250 Basic Orbital Shaker

Kern 440-47 N (scale)

Kryostat CM 3050 S

Megafuge $1.0 \mathrm{R}$

Microm HM 400 Microtome

Multichannel Equalizer Matrix Pipette

Mupid®-exU Submarine

Electrophoresis System
Peqlab, Erlangen, Germany

Becton Dickinson, Madrid, Spain
Applied Biosystems, Carlsbad, USA

Brand, Wertheim, Germany

Siemens Healthcare Diagnostics Inc., Eschborn, Germany

Agfa, Köln, Germany

MWG Biotech, Ebersberg, Germany

Eppendorf, Hamburg, Germany

Eppendorf, Hamburg, Germany

Applied Biosystems, Foster City, USA

ART Prozess- \& Labortechnik, Mühlheim, Germany

IKA® Werke, Staufen, Germany

Kern \& Sohn GmbH, BalingenFrommern, Germany

Leica, Wetzlar, Germany

Heraeus, Hanau, Germany

Thermo Fisher Scientific, Karlsruhe, Germany

Thermo Fisher Scientific, Karlsruhe, Germany

Gel Company GmbH Tübingen 


\section{Germany}

NanoDrop $\AA^{\circledR} \quad$ ND-1000 UV/VIS Peqlab, Erlangen, Germany spectrophotometer

Olympus CKX41 with ALTRA20 soft Olympus Hamburg, Germany imaging system

PowerEase ${ }^{\circledR} 500$ Power supply Invitrogen, Darmstadt, Germany

RTcolor spot camera with MetaVue Visitron Systems Inc., Puchheim, 6.3r3 software Germany and Molecular Devices, Sunnyvale, CA, USA

Sartorius Handy H51-D (scale) Sartorius AG, Göttingen, Germany

Thermomixer comfort Eppendorf, Hamburg, Germany

Ultrasonoscope Sonoplus hp 70 Bandelin Electronics, Berlin, Germany

XCell II ${ }^{\mathrm{TM}}$ Blot Module Invitrogen, Darmstadt, Germany

XCell SureLock® Mini-Cell Invitrogen, Darmstadt, Germany 


\section{II.2. Methods}

\section{II.2.1. Cell culture (in vitro experiments)}

\section{II.2.1.1. Isolation of primary hepatic stellate cells}

Primary human hepatic stellate cells (HSC) were isolated in co-operation between the our working group and the Center for Liver Cell Research (Department of Surgery, University of Regensburg, Germany) using a modified two-step EGTA/ collagenase perfusion procedure (Hellerbrand et al., 2008, Ryan et al., 1993,Weiss et al., 2002).

Human liver tissues used for cell isolation were obtained from liver resections of patients undergoing partial hepatectomy for metastatic liver tumors of colorectal cancers. Experimental procedures were performed according to the guidelines of the charitable state controlled foundation HTCR (Human Tissue and Cell Research), with the informed patient's consent approved by the local ethical committee of the University of Regensburg (Thasler et al., 2003).

Further, HSC were isolated on a regular basis within our working group from 8-12 week old female BALB/c mice (Charles River Laboratories, Sulzfeld, Germany) according to procedures described previously (Hellerbrand et al., 1996).

Human and murine HSC provided for this project, were activated by cell culture on uncoated tissue culture dishes as described (Hellerbrand et al., 1996).

\section{II.2.1.2. Cultivation of cell lines}

All cell culture work was done in a laminar flow bio-safety cabinet (Hera Safe, Heraeus, Osterode, Germany). The cells were cultivated under a $10 \% \mathrm{CO}_{2}$ atmosphere at $37{ }^{\circ} \mathrm{C}$ in a cell incubator (Hera Cell).

As a culture medium DMEM containing $4.5 \mathrm{~g} / \mathrm{l}$ glucose and $300 \mu \mathrm{g} / \mathrm{ml}$ L-glutamine supplemented with $10 \%(\mathrm{v} / \mathrm{v}) \mathrm{FCS}, 400 \mathrm{U} / \mathrm{l}$ penicillin and $50 \mathrm{\mu g} / \mathrm{ml}$ streptomycin was used. For cell splitting cells were washed with PBS and detached with trypsin $(0.05 \%) / E D T A(0.02 \%)$ (PAA Laboratories, Cölbe, Germany). The reaction was stopped by addition of fresh culture medium. Subsequently, cells were 
resuspended and distributed to new cell culture flasks. Cell growth and morphology were controlled using microscopy (Olympus CKX41 with ALTRA20 Soft Imaging System, Olympus, Hamburg, Germany). Cell culture waste was autoclaved before disposal (Sanoclav; Wolf, Geislingen, Germany).

\section{II.2.1.3. Determination of cell number and viability}

Cell number and viability were determined by trypan blue exclusion test. The cell suspension was diluted 1:2 with trypan blue solution (Sigma, Deisenhofen, Germany) and applied on a Neubauer haemocytometer (Marienfeld $\mathrm{GmbH}$, Lauda- Königshofen, Germany). Cells with impaired cell membrane integrity were stained blue, and could be clearly distinguished from intact cells under microscopic inspection. After counting the cells in all four quadrants of the haemocytometer the cell number could be calculated with the following equation:

$$
\begin{aligned}
& \text { Cell number } / \mathbf{m l}=\mathbf{C} \times \mathbf{x} \text { df } \times 10^{4} / \mathbf{4} \\
& \begin{array}{l}
C=\text { counted cell number in all four quadrants } \\
d f=\text { dilution factor }
\end{array}
\end{aligned}
$$

The ratio of viable cells could be determined by setting the number of unstained cells in relation to the total cell number.

\section{II.2.1.4. Oleic acid preparation}

Oleic acid (C18:1 cis- 9$)$ is a mono-unsaturated omega-9 fatty acid and is the most abundant fatty acid in human adipose tissue (Kokatnur et al., 1979).

Preparation of the oleic acid stock solution was carried out as described by Cousin et al. (Cousin et al., 2001).

First $0.1 \mathrm{~N} \mathrm{NaOH}$ was prepared, sterile-filtered and then heated to $70{ }^{\circ} \mathrm{C}$. Oleic acid was then added in the right amount and solved to get a $100 \mathrm{mM}$ oleic acid stock solution. Additionally a $10 \%(\mathrm{w} / \mathrm{v})$ aqueous free fatty acid free BSA solution was prepared, sterile-filtered and then heated to $55{ }^{\circ} \mathrm{C}$ in a water bath. $10 \mathrm{mM}$ 
oleic acid/ BSA solution was obtained by complexation of the appropriate amount of oleic acid stock solution with $10 \% \mathrm{BSA}$ at $55{ }^{\circ} \mathrm{C}$ for $30 \mathrm{~min}$. The obtained solution was then cooled to $25{ }^{\circ} \mathrm{C}$ and stored at $-20{ }^{\circ} \mathrm{C}$ until use. For in vitro experiments the $10 \mathrm{mM}$ oleic acid/ BSA stock solution was heated for $15 \mathrm{~min}$ at 55 ${ }^{\circ} \mathrm{C}$ and subsequently cooled down to working temperature $\left(37^{\circ} \mathrm{C}\right)$ before use. Samples indicated as controls received an appropriate amount of vehicle stock solution, which was prepared analogous to the oleic acid/ BSA stock solution, only without adding the fatty acid.

\section{II.2.1.5. Tests with cells and cell supernatant}

Cell supernatant was tested using ELISA. The concentration of IL-8 was assessed using the human CXCL8/IL-8 DuoSet ${ }^{\circledR}$ ELISA kit (R\&D systems Wiesbaden, Germany) according to the manufacturer's instructions. A 96-well plate was coated with the capture antibody (mouse anti-human IL-8). Then unspecific binding sites were blocked with a blocking buffer (1\% BSA and $0.05 \mathrm{Na}_{3} \mathrm{~N}$ in PBS). After washing with TBST supernatants and standard were applied to the wells. IL-8 was detected using a biotinylated detection antibody (goat anti-human II-8). After incubation with streptavidin-HRP application of a substrate solution (Tetramethylbenzidine $+\mathrm{H}_{2} \mathrm{O}_{2}$ ) produced a color reaction. The reaction was stopped with $2 \mathrm{~N} \mathrm{H}_{2} \mathrm{SO}_{4}$ and measured as the optical density at $450 \mathrm{~nm}$.

Effects on cell viability were assessed by lactate dehydrogenase (LDH) leakage into the culture medium. Supernatant was centrifuged at $20,000 \mathrm{~g}$ for $5 \mathrm{~min}$ to pellet detached cells and cell debris. The clear supernatant was then used for analysis of LDH content. LDH can be quantified indirectly by reduction of nicotinamide adenine dinucleotide $\left(\mathrm{NAD}_{+}\right)$to $\mathrm{NADH}$ by a lactate dehydrogenase catalyzed oxidation of L-lactate to pyruvate. The measurements were performed at the Department of Clinical Chemistry and Laboratory Medicine (University of Regensburg, Germany), using the Lactate dehydrogenase L-P (LDLP) kit (Bayer HealthCare, Leverkusen, Germany) according to the manufacturer's instructions and adapted to the Advia 1800 analyzer (Siemens Healthcare Diagnostics, Eschborn, Germany). 
Cells were examined using PCR and Western blotting. These methods are described in detail later (in vivo experiments).

\section{II.2.2. Genotyping}

The genotype of the PI3K p110 $\gamma$ knockout mice was tested by isolation of DNA from the tip of the tail and subsequent PCR with specific primers, which were synthesised by SIGMA Genosys (Hamburg, Germany).

DNA isolation was done using the QIAamp ${ }^{\circledR}$ DNA Mini Kit (Qiagen, Hilden) according to the manufacturer's instructions. First the tissue was lysed in a Proteinase $\mathrm{K}$ solution at $56{ }^{\circ} \mathrm{C}$, while shaking (Thermomixer, Eppendorf, Hamburg, Germany). After ca. 3 hours a specific buffer was added to the homogenate and Proteinase $\mathrm{K}$ was inactivated at $70^{\circ} \mathrm{C}$ for $10 \mathrm{~min}$. An ethanol containing binding buffer was then added to the sample to provide the right conditions for the binding of the DNA to the membrane of a spin column. The homogenate was then added to the column and several washing steps were performed, until DNA could be eluted with an eluting buffer (Buffer $\mathrm{AE}$ ) and stored at $-20^{\circ} \mathrm{C}$.

For the PCR, the following primers were used:

\begin{tabular}{|l|l|}
\hline Primer & Sequence \\
\hline - PI3K WT forward & 5' -TCAGGCTCGGATATTAGGTA- 3' \\
\hline - PI3K WT reverse & 5' -GCCCAATCGGTGGTAGAACT - 3' \\
\hline - PI3K Mut forward & 5' -TACTGCAGAGGACAGAGGAGA - 3' \\
\hline - PI3K Mut reverse & 5' -GGGGTGGGATTAGATAAATG - 3' \\
\hline
\end{tabular}

Isolated DNA and primers were mixed with a prefabricated Master-mix:

$25 \mu$ I Pre-Aliquoted Reddy Mix ${ }^{\top M}$ PCR Master Mix (ABgene, Surrey, UK)

$1.5 \mu \mathrm{l}$ primer forward

$1.5 \mu$ l primer reverse

$2 \mu \mathrm{DNA}$ 
The following program was used for the PCR reaction:

$94^{\circ} \mathrm{C} 2 \min$

$94^{\circ} \mathrm{C} 30 \mathrm{~s}$

$56^{\circ} \mathrm{C} 30 \mathrm{~s}$

$x 30$ cycles

$72^{\circ} \mathrm{C} 45 \mathrm{~s}$

$4^{\circ} \mathrm{C} \infty$

The PCR product was then analyzed by loading on a $1.5 \%$ agarose gel with SYBR® Safe DNA gel stain $(1: 10,000)$ (Invitrogen, Darmstadt, Germany). For the electrophoresis the Mupid@-exU Submarine Electrophoresis System (Gel Company GmbH Tübingen Germany) was used. Mutant primers (Mut) lead only to PCR product in samples from knockout mice, whereas wild-type primers (WT) only in samples from wild-type-mice. The PCR product length also differed slightly (see Figure II.1.)

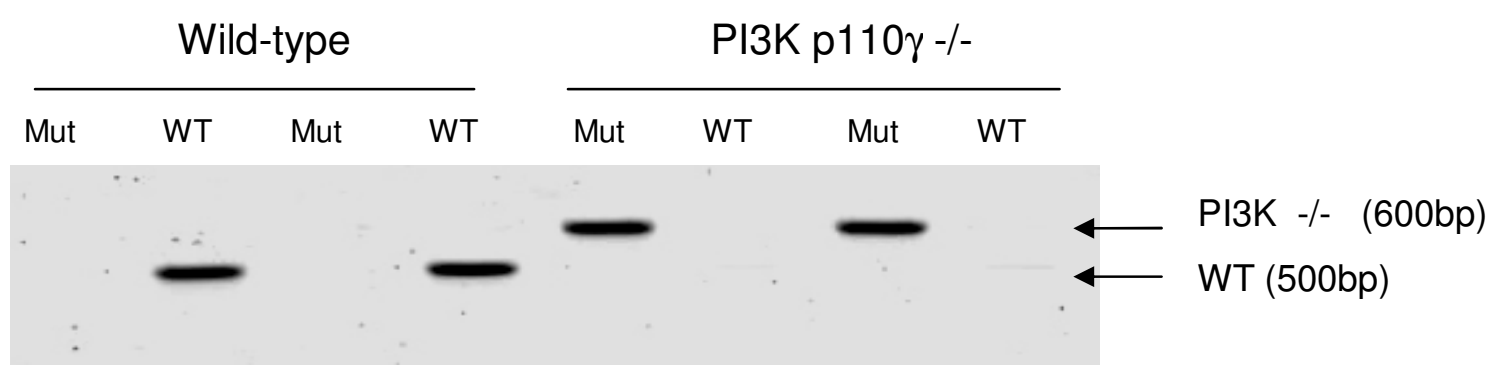

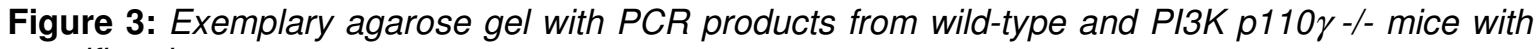
specific primers

\section{II.2.3. Animal models}

At the end of all experiments, mice were sacrificed by $\mathrm{CO}_{2}$ asphyxiation according to the guidelines of the Central Animal Facility ( $Z T L)$ of the University of Regensburg (Regensburg) (Central Animal Facility (ZTL) of the University of Regensburg 2009). 
Liver Tissue was snap frozen in liquid nitrogen immediately after organ explantation and stored at $-80{ }^{\circ} \mathrm{C}$, whereas tissue for histological analysis was either fixed for 24 hours in buffered formaldehyde solution (3.7\% in PBS) at room temperature, dehydrated by graded ethanol and embedded in paraffin or embedded in Tissue Tek ${ }^{\circledR}$ (Sakura, Finetek, Zoeterwoude, Netherlands) and stored at $-80{ }^{\circ} \mathrm{C}$. For serum analysis blood was collected by heart puncture. After clotting (30 min on ice) blood was centrifuged $(10,000 \mathrm{~g}, 5 \mathrm{~min}$ ) to remove cellular components. Serum (supernatant) was used for further analysis or stored at -20 ${ }^{\circ} \mathrm{C}$.

\section{II.2.3.1. Bile duct ligation}

Female PI3K p110 $\gamma$ knockout mice and C57BI/6 wild-type mice (WT) were randomly allocated to 4 experimental groups $(n=6)$. Bile duct ligation (BDL) or sham operation was performed as described previously (Uchinami et al., 2006). After midline laparotomy $(1 \mathrm{~cm})$ the common bile duct was exposed and ligated three times. Two ligatures were placed in the proximal portion of the bile duct and one ligature was located in the distal portion of the bile duct. The bile duct was then cut between the ligatures. Then the abdomen was closed again in layers. In sham operations the bile duct was touched three times with a forceps. After an experimental period of 3 weeks, blood and livers of the operated mice were harvested for further analysis.

\section{II.2.3.2. NASH model}

Female PI3K p110 $\gamma$ deficient mice and C57BI/6 wild-type mice (WT) were randomly allocated to 4 experimental groups $(n=6)$ receiving either standard chow (SC) or a high fat (HFD) diet consisting of $17 \%$ fat (lard and cocoa butter) supplemented with $1.25 \%$ cholesterol and $0.5 \%$ cholate, according to Matsuzawa et al. which has been shown to closely resemble pathophysiological changes observed in human NASH (Matsuzawa et al., 2007). After 12 weeks mice were sacrificed and blood and tissue was harvested. 


\section{II.2.4. Serum analysis}

Analysis of serological parameters was performed at the Department of Clinical Chemistry and Laboratory Medicine (University of Regensburg, Germany) using standard enzymatic assay kits according to the manufacturer's instructions (Bayer HealthCare, Leverkusen, Germany) and adapted to the ADVIA 1800 analyzer (Siemens Healthcare Diagnostics Inc., Eschborn, Germany).

The serum concentration of insulin and adiponectin was assessed using ELISA kits (DRG Instruments, Marburg, Germany and R\&D systems, Wiesbaden, Germany, respectively) according to the manufacturer's instructions.

\section{II.2.5. Histology and Immunohistochemistry}

Liver sections were processed as described in II.2.3. Slices $(5 \mu \mathrm{m})$ were made using the Microm HM 400 Microtome (Thermo Fisher Scientific, Karlsruhe, Germany) and mounted on glass slides (Menzel-Gläser, Braunschweig, Germany) to use for different staining procedures. Digital images were captured with an Olympus CKX41 microscope equipped with the ALTRA20 Soft Imaging System (Olympus, Hamburg, Germany).

\section{II.2.5.1. Haematoxylin/ Eosin staining}

The tissue mounted on glass slides was deparaffinised with Roti®-Histol (Carl Roth $\mathrm{GmbH}$, Karlsruhe, Germany) a non harmful substitute to xylene. Then, the tissue was rehydrated and basophilic structures (cell nuclei) were stained with an aqueous solution of haematoxylin, followed by staining of acidophilic components (amino acids) with eosin. Following dehydration in an ethanol gradient the tissue was covered with Roti®-Histo Kit (Carl Roth GmbH, Karlsruhe, Germany) and a thin glass cover slip (Carl Roth $\mathrm{GmbH}$ ). 


\section{II.2.5.2. Sirius red staining (Collagen stain)}

Slides were processed like described for the haematoxylin/ Eosin staining. After rehydration slides were washes in PBST and then incubated for 30 minutes in a solution of saturated picric acid containing $0.1 \%$ sirius red and $0.1 \%$ fast green. Sirius red is an acidophilic dye which in combination with picric acid specifically binds to collagen. Fast green was used as a counter-stain.

\section{II.2.5.3. Immunohistochemistry for $\alpha \mathrm{SMA}$, HNE and caspase 3}

The tissue mounted on slides was deparaffinated and rehydrated as described before. The slides were then incubated in TBST for 16 hours at $4^{\circ} \mathrm{C}$. For the staining procedure the LSAB+ System HRP-Kit (Dako, Hamburg, Germany) was used according to the manufacturer's instructions (labelled streptavidin biotin technique).

After washing in TBST, the tissue was incubated for $10 \mathrm{~min}$ with a peroxidase block $\left(3 \% \mathrm{H}_{2} \mathrm{O}_{2}\right)$ to quench endogenous peroxidase activity. Subsequently, the tissue was incubated for 30 minutes with a primary antibody:

\begin{tabular}{|l|l|}
\hline Antibody & Dilution (in TBS/BSA 1\%) \\
\hline $\begin{array}{l}\text { mouse } \alpha \text {-alpha smooth muscle actin (Abcam, } \\
\text { Cambridge, UK) }\end{array}$ & $1: 200$ \\
\hline $\begin{array}{l}\text { rabbit anti-HNE antiserum (Alpha Diagnostic } \\
\text { international, San Antonio, USA) }\end{array}$ & $1: 5,000$ \\
\hline $\begin{array}{l}\text { rabbit active Caspase-3 (Epitomics, Burlingame, } \\
\text { USA) }\end{array}$ & $1: 100$ \\
\hline
\end{tabular}

After washing in TBST the specimen were covered with a biotinylated link for 15 min, followed by incubation with peroxidase-labelled streptavidin (15 min). Staining was made visible with a substrate-chromogen (3,3'-diaminobenzidine) solution 
(incubation time: $1-5 \mathrm{~min}$ ). After rinsing with $\mathrm{H}_{2} \mathrm{O}_{\text {dist. }}$ the tissue was dipped into an aqueous solution of haematoxylin for 15 seconds for counterstaining.

\section{II.2.5.4. Sudan III staining (Lipid stain)}

For the lipid stain it was necessary to use cryo-sections. For this, sections of the liver were embedded in TissueTek® (SAKURA, Finetek, Zoeterwoude, Netherlands) and frozen in liquid nitrogen. Sections were then stored at $-80^{\circ} \mathrm{C}$. Slices of $8 \mu \mathrm{m}$ were made using the Kryostat CM $3050 \mathrm{~S}$ (Leica, Wetzlar, Germany) and mounted on pre-cooled SuperFrost $\AA^{\circledR}$ Plus glass slides (MenzelGläser, Braunschweig, Germany). The tissue was dried at room temperature for approx. 1hour, rehydrated in TBS and then incubated in Sudan III solution (Carl Roth $\mathrm{GmbH}$, Karlsruhe, Germany) for $20 \mathrm{~min}$. As a counter-stain slides were shortly incubated in haematoxylin. Slides were then covered with aqueous mounting medium (Dako, Hamburg, Germany).

\section{II.2.5.5. TUNEL assay (TdT-mediated dUTP-biotin nick end labelling)}

The tissue mounted on slides was deparaffinised and rehydrated as described before. The slides were then incubated in paraformaldehyde for 15 min. After washing in PBS slides were incubated with Proteinase $\mathrm{K}$ for $10 \mathrm{~min}$. For the staining procedure the Dead End Fluorimetric TUNEL system (Promega, Mannheim, Germany) was used according to the manufacturer's instructions. Slides were incubated for 60 min with the NucMix in the dark at $37{ }^{\circ} \mathrm{C}$. After washing slides were then covered with Vectashield-Dapi-H-100 (Vecta Laboratories, Burlingame, USA) and stored overnight at $4{ }^{\circ} \mathrm{C}$.

\section{II.2.5.6. Quantification of positive labeled areas}

The specific staining of specimen was quantified by image analysis. 10 fields per section were captured at 100x magnification and analyzed using an RTcolor spot camera (Visitron Systems Inc., Puchheim, Germany). Image analysis was 
performed using MetaVue 6.3r3 software (Molecular Devices, Sunnyvale, CA, USA). Detection levels were set for the color of staining based on an intensely labelled point and a default color threshold. The degree of labeling (\%) in each section was determined from the area within the color range divided by the total area.

\section{II.2.6. Quantification of hepatic Free fatty acids (FFA) and Triglyceride (TG) content}

To quantify hepatic total free fatty acids or triglyceride content total lipid was extracted from liver tissue sections using the method of Bligh and Dyer with slight modifications (BLIGH and Dyer W.J., 1959). To extract the lipids, liver sections (approx. $50 \mathrm{mg}$ ) were weighed into $1 \mathrm{ml}$ of a chloroform/methanol mix (2:1 v/v) and incubated for $1 \mathrm{~h}$ at room temperature on an orbital shaker. After addition of $200 \mu \mathrm{l}$ $\mathrm{H}_{2} \mathrm{O}_{\text {dist., }}$ vortexing and centrifugation for $5 \mathrm{~min}$ at $3000 \mathrm{~g}$, the lower lipid phase was collected and dried at room temperature. The lipid pellet was then re-dissolved in $60 \mu \mathrm{l}$ tert-butanol and $40 \mu \mathrm{l}$ of a Triton X-114/methanol mix (2:1 v/v).

Total FFA content was quantified using the Free Fatty Acids, Half Micro Test by Roche Applied Science and triglyceride content using the Roche Diagnostics Triglyceride assay (Roche Diagnostics, Mannheim, Germany) according to the manufacturer's instructions. Both assays use an enzymatic colorimetric reaction for detection. Samples were measured at $540 \mathrm{~nm}$ with a spectrophotometer (EMax® Microplate Reader, MWG Biotech, Ebersberg, Germany).

\section{II.2.7. Quantification of mRNA expression}

\section{II.2.7.1. Isolation of RNA}

For the isolation of total RNA the RNeasy® mini kit (Qiagen, Hilden, Germany) was used, according to the manufacturer's instructions.

First the liver samples were homogenized with the MICCRA D-1 Homogenisator (ART Prozess- \& Labortechnik, Mühlheim, Germany) in the presence of a lysis buffer (RLT-buffer) which contains guanidine isothiocyanate and was 
supplemented with $\beta$-Mercaptoethanol, so that RNases were immediately inactivated. Then the homogenate was applied to shredder-columns to get rid of debris. The flow through was then applied to columns which contain hydrophilic silicon-gel membranes, were RNA can bind in the presence of suitable buffer systems. Ethanol containing buffer was then added to the column to provide the right conditions for the binding of the RNA to the membrane. After several washing steps DNA was removed by incubation of the samples with DNase (Qiagen, Hilden, Germany). After further washing steps RNA was eluted from the column with RNAse free water (DEPC-water). The concentration of RNA was measured

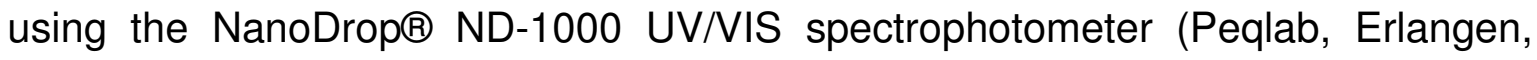
Germany).

\section{II.2.7.2. Reverse Transcription (RT-PCR)}

The transcription of RNA to complementary DNA (CDNA) was performed using the Reverse Transcription System Kit (Promega, Mannheim, Germany) which contains a reverse transcriptase from the avian myeloblastosis virus (AMV). The following components were pipetted together to a master mix:

$4 \mu \mathrm{l} \mathrm{MgCl}_{2}(25 \mathrm{mM})$

$2 \mu \mathrm{l} 10 \mathrm{x}$ reverse transcription buffer

$2 \mu \mathrm{dNTP} \operatorname{mix}(10 \mathrm{mM})$

$1 \mu \mathrm{l}$ random primer

$0.5 \mu \mathrm{l}$ Rasin (ribonuclease inhibitor)

$0.6 \mu \mathrm{l}$ AMV reverse transcriptase

$1 \mu \mathrm{g}$ of RNA was then taken to a volume of $12 \mu \mathrm{l}$ with RNAse free water and mixed with $10.1 \mu \mathrm{l}$ of the master mix. For reverse transcription the samples were incubated for $30 \mathrm{~min}$ at $42{ }^{\circ} \mathrm{C}$ using the GeneAmp ${ }^{\circledR}$ PCRcycler (Applied Biosystems, Foster City, USA). In order to denature the AMV RT the temperature was then raised to $99{ }^{\circ} \mathrm{C}$ for $5 \mathrm{~min}$. After cooling to $4{ }^{\circ} \mathrm{C}$ the obtained cDNA was

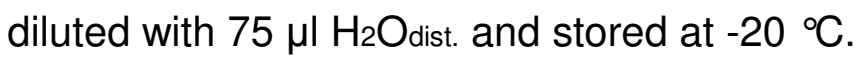




\section{II.2.7.3. Quantitative real time polymerase chain reaction (PCR)}

Quantitative real-time polymerase chain reaction (qRT-PCR) was used to quantify the expression of specific mRNA. Quantification was done using the LightCycler II system (Roche Diagnostics, Mannheim, Germany) with SYBR ${ }^{8}$ Green (QuantiTect SYBR® Green PCR Kit, Qiagen, Hilden, Germany) as the fluorescent reagent. Additionally to a conventional polymerase chain reaction (PCR) this system offers the possibility of quantification, which is accomplished by fluorescence measurements at the end and/or during a PCR cycle. SYBR $\circledast$ Green intercalates with double-strand DNA, so that the fluorescence signal increases proportionally to the amount of PCR products. To quantify the expression of a specific gene of interest the $\triangle \mathrm{CT}$ method was used. The CT (cycle threshold) value marks the beginning of the exponential phase of the reaction, when the fluorescence of the sample rises above the threshold level. With this method the $x$ fold expression of the gene of interest in a sample was calculated referring to a control, which was set 1 (Calibrator). As housekeeper a gene was used which is expressed constantly (18s).

\section{Calculation:}

Step1: $\quad$ Normalising to the housekeeper (18s RNA)

$$
\mathrm{CT} \text { gene of interest }-\mathrm{CT} \text { housekeeper }=\Delta \mathrm{CT} \text { sample }
$$

Step 2: $\quad$ Normalising to the Calibrator (control set 1)

$$
\Delta \mathrm{CT} \text { sample }-\Delta \mathrm{CT} \text { Calibrator }=\Delta \Delta \mathrm{CT}
$$

Step 3: $\quad$ Calculation of the $x$-fold expression

$$
x-\text { fold expression }=2^{(-\Delta \Delta C T)}
$$


The PCR reaction was mixed as follows:

$2.5 \mu \mathrm{LEPC}-\mathrm{H}_{2} \mathrm{O}$

$0.25 \mu$ l primer forward $(20 \mu \mathrm{M})$

$0.25 \mu$ l primer reverse $(20 \mu \mathrm{M})$

$5 \mu \mathrm{I}$ SYBR ${ }^{\circ}$ Green PCR Master Mix

$2 \mu \mathrm{l}$ CDNA

or

$2 \mu \mathrm{I}$ DEPC- $\mathrm{H}_{2} \mathrm{O}$

$1 \mu$ I QIAGEN QuantiTect Primer Assay

$5 \mu$ I SYBR $B$ Green PCR Master Mix

$2 \mu \mathrm{l}$ CDNA

Measurements were performed using the ABI PRISM ${ }^{\circledR} 7900$ HT Sequence detection system (Taqman) and the corresponding SDS 2.3 software (Applied Biosystems, Carlsbad, USA), which was also used for the analysis of the results.

The following program was used for the PCR reaction:

$50^{\circ} \mathrm{C} 2 \mathrm{~min}$

$95^{\circ} \mathrm{C} 15 \mathrm{~min}$

$95^{\circ} \mathrm{C} 15 \mathrm{~s}$

$55^{\circ}-60^{\circ} 20 \mathrm{~s}$ x 45 cycles

$72^{\circ} \mathrm{C} 25 \mathrm{~s}$

Melting curve:

$60^{\circ} \mathrm{C}$ to $94^{\circ} \mathrm{C} 0.1^{\circ} \mathrm{C} / \mathrm{s}$

Fluorescence was measured at the end of each elongation step $\left(72^{\circ} \mathrm{C}\right)$, and continually during the measurement of the melting curve to analyze the amplified DNA. Additionally $5-10 \mu \mathrm{l}$ of the PCR product were then mixed with loading buffer (Peqlab, Erlangen, Germany) and loaded on a $1-2 \%$ agarose gel with SYBR $\AA$ 
Safe DNA gel stain $(1: 10,000)$ (Invitrogen, Darmstadt, Germany) to determine PCR product length.

\section{II.2.8. Western blotting}

\section{II.2.8.1. Isolation of proteins}

Proteins were extracted from liver samples using Pierce T-PER Tissue Protein Extraction Reagent (Thermo Fisher Scientific Inc, Rockford, USA) as lysis buffer. The buffer was supplemented with protease inhibitors prior to use:

10ml Pierce T-PER Tissue Protein Extraction Reagent $100 \mu \mathrm{l} \mathrm{PMSF} 100 \mathrm{mM}$ $100 \mu \mathrm{Na}_{3} \mathrm{VO}_{4}$ (Vanadate) $100 \mathrm{mM}$

1x Complete, Mini; Protease Inhibitor Cocktail Tablets (Roche Applied Science, Mannheim, Germany)

Liver samples were homogenized with the MICCRA D-1 Homogenisator (ART Prozess- \& Labortechnik, Mühlheim, Germany) in $300 \mu$ lysis buffer. Then the homogenate was sonicated with an ultrasonoscope (Sonoplus hp 70, Bandelin Electronics, Berlin, Germany) $10 \times 3 \mathrm{~s}$ at an intensity of $40 \%$. Subsequently, the proteins were separated from the non soluble cell components by centrifugation at $10,000 \mathrm{~g}\left(5 \mathrm{~min}, 4^{\circ} \mathrm{C}\right)$. The protein solution was transferred into new reaction tubes and stored at $-20{ }^{\circ} \mathrm{C}$.

\section{II.2.8.2. Analysis of Protein concentration (BCA assay)}

To determine the concentration of protein samples the BCA Protein Assay Kit (Pierce, Rockford, USA) was used according to the manufacturer's instructions.

With this assay protein concentration can be detected via a highly sensitive colorimetric reaction of copper with bicinchoninic acid (BCA). The first step is the chelation of copper with protein in an alkaline environment to form a blue-colored complex. In the second step BCA reacts with the cuprous cation $\mathrm{Cu}^{1+}$. The purple- 
coloured reaction product is formed by the chelation of two molecules of BCA with one cuprous ion. The BCA/copper complex is water-soluble and exhibits a strong linear absorbance at $562 \mathrm{~nm}$ with increasing protein concentrations.

$200 \mu \mathrm{l}$ of alkaline BCA/copper (II) solution (50 parts of solution A mixed with 1 part of solution B) was added to $5 \mu$ of protein solution in a 96-well plate incubated for $5-15 \mathrm{~min}$ at $37^{\circ} \mathrm{C}$. Thereafter samples were measured at $562 \mathrm{~nm}$ with a spectrophotometer (EMax® Microplate Reader, MWG Biotech, Ebersberg, Germany). Protein concentration could then be determined using a Standard curve made with BSA.

\section{II.2.8.3. SDS polyacrylamid gel electrophoresis (SDS-PAGE)}

For the SDS-PAGE the NuPAGE® -System of Invitrogen (Darmstadt, Germany) was used.

Gels:

NuPAGE® Novex $4-12 \%$ Bis-Tris gel 1.0mm, 10well NuPAGE $\circledast$ Novex $12 \%$ Bis-Tris gel 1.0mm, 10well

Running buffer: $25 \mathrm{ml}$ NuPAGE® MOPS SDS Running Buffer $(20 \mathrm{x})$

$475 \mathrm{ml} \mathrm{H}_{2} \mathrm{O}_{\text {millipore }}$

$500 \mu \mathrm{l}$ NuPAGE® Antioxidant

First, protein solutions were prepared with XT Sample buffer (4x) (Biorad, München, Germany) and NuPAGE® Sample Reducing agent (10x) and diluted to a protein concentration of $1-4 \mu \mathrm{g} / \mu \mathrm{l}$ with PBS. These mixes were heated at $95^{\circ} \mathrm{C}$ for 5 minutes for denaturation.

$25 \mu \mathrm{l}(25-100 \mu \mathrm{g})$ of the protein samples were then applied to the slots of a prefabricated gel. As the size marker the Full Range Rainbow Molecular Weight Marker (GE Healthcare, Freiburg, Germany) was used. 1 hour of electrophoresis was done using the PowerEase $\AA 500$ Power supply calibrated to $90 \mathrm{~mA} / 160 \mathrm{~V}$ and the XCell SureLock $®$ Mini-Cell (Invitrogen, Darmstadt, Germany). 


\section{II.2.8.4. Protein transfer}

After electrophoretic separation proteins were transferred onto a nitrocellulose membrane (Invitrogen, Darmstadt, Germany).

Transfer buffer: $25 \mathrm{ml}$ NuPAGE ${ }^{\circledR}$ Transfer Buffer (20x)

$50 \mathrm{ml}$ Methanol

$425 \mathrm{ml} \mathrm{H}_{2} \mathrm{O}_{\text {millipore }}$

$500 \mu \mathrm{l}$ NuPAGE® Antioxidant

For the protein transfer the XCell II $^{\mathrm{TM}}$ Blot Module (Invitrogen, Darmstadt, Germany) was used. The blotting was done at $220 \mathrm{~mA} / 20 \mathrm{~V}$ for 1.5 hours.

\section{II.2.8.5. Protein detection}

After transfer the nitrocellulose membrane with the blotted proteins was washed in blocking buffer (TBST/5\% milk) to block unspecific binding sites.

Proteins were then detected with specific primary antibodies (see following table).

\begin{tabular}{|c|c|}
\hline Antibody & Dilution (in TBST/BSA 5\%) \\
\hline $\begin{array}{l}\text { - anti-AMPK (New England Biolabs, Frankfurt, } \\
\text { Germany) }\end{array}$ & $1: 1000$ \\
\hline $\begin{array}{l}\text { - anti-phospho -AMPK } \alpha \text { (New England Biolabs, } \\
\text { Frankfurt, Germany) }\end{array}$ & $1: 2000$ \\
\hline $\begin{array}{l}\text { - rabbit anti-AKT (New England Biolabs, Frankfurt, } \\
\text { Germany) }\end{array}$ & $1: 1000$ \\
\hline $\begin{array}{l}\text { - rabbit anti-phospho -AKT (New England Biolabs, } \\
\text { Frankfurt, Germany) }\end{array}$ & $1: 1000$ \\
\hline
\end{tabular}




\begin{tabular}{|l|l|}
\hline $\begin{array}{l}\text { rabbit anti-p70 S6 K (New England Biolabs, Frankfurt, } \\
\text { Germany) }\end{array}$ & $1: 1000$ \\
\hline $\begin{array}{l}\text { rabbit anti-phospho - p70 S6 K (New England } \\
\text { Biolabs, Frankfurt, Germany) }\end{array}$ & $1: 1000$ \\
\hline $\begin{array}{l}\text { mouse anti-AdipoR1 (AG Buechler, Department of } \\
\text { Internal medicine I, University of Regensburg) }\end{array}$ & $1: 1000$ \\
\hline $\begin{array}{l}\text { rabbit anti-Collagen type I antibody (Rockland, PA, } \\
\text { USA) }\end{array}$ & $1: 5000$ \\
\hline $\begin{array}{l}\text { mouse anti- } \alpha \text {-tubulin (Santa Cruz, Heidelberg, } \\
\text { Germany) }\end{array}$ & $1: 1000$ \\
\hline
\end{tabular}

Membranes were incubated with the primary antibody over night at $4^{\circ} \mathrm{C}$. After washing in TBST membranes were incubated with specific secondary antibodies, which were conjugated with horseradish peroxidise (HRP).

\begin{tabular}{|l|l|}
\hline Antibody & Dilution (in TBST/milk 5\%) \\
\hline $\begin{array}{l}\text { goat anti rabbit IgG-HRP (Santa Cruz, Heidelberg, } \\
\text { Germany) }\end{array}$ & $1: 3000$ \\
\hline $\begin{array}{l}\text { goat anti mouse IgG-HRP (Santa Cruz, Heidelberg, } \\
\text { Germany) }\end{array}$ & $1: 3000$ \\
\hline
\end{tabular}

For the detection of now HRP-labeled proteins the ECL Plus Western Blotting Detection System (GE Healthcare, Freiburg, Germany) was used. This system utilizes chemiluminescence technology for the detection of proteins. It consists of 
the acridan substrate Lumigen PS-3, which is converted to an acridinium ester intermediate when catalyzed by HRP. The ester intermediate reacts with peroxide in alkaline conditions and emits light, which can be detected by autoradiography. After incubation in ECL solution for 1 min proteins were detected using Amersham Hyperfilm $^{T M}$ ECL films (GE Healthcare, Freiburg, Germany) and the Curix 60 automatic film developer (Agfa, Köln, Germany).

\section{II.2.9. Statistics}

Statistical analysis was done using bi-factorial analysis of variance (two-way ANOVA) and Tukey post-hoc test or Student's unpaired t-test. Values were presented as mean \pm SEM. $p<0.05$ was defined to be the level of significance. SigmaPlot Software 11.0. (Systat Software, Erkrath, Germany) was used for all calculations. 


\section{Results}

\section{III.1. Analysis of PI3K p110 $\gamma$ expression in diseased murine and human liver tissue}

So far, no information has been available regarding the expression of PI3K p110 $\gamma$ in chronic liver disease. Thus, we first assessed PI3K p110 $\gamma$ mRNA expression in different murine models of chronic liver injury by quantitative PCR. We observed a significantly increased expression in the BDL model, which is a well established liver fibrosis model (Ezure et al., 2000,Gabele et al., 2009,Isayama et al., 2006) (Fig. 4a), as well as in two dietary NASH models, namely the MCD model (Weltman et al., 1996) (Fig 4b) and a high fat diet (HFD) model (Fig 4c), which are also well established (Gabele et al., 2011b,Gabele et al., 2011a,Matsuzawa et al., 2007,Paigen et al., 1985).

(a)

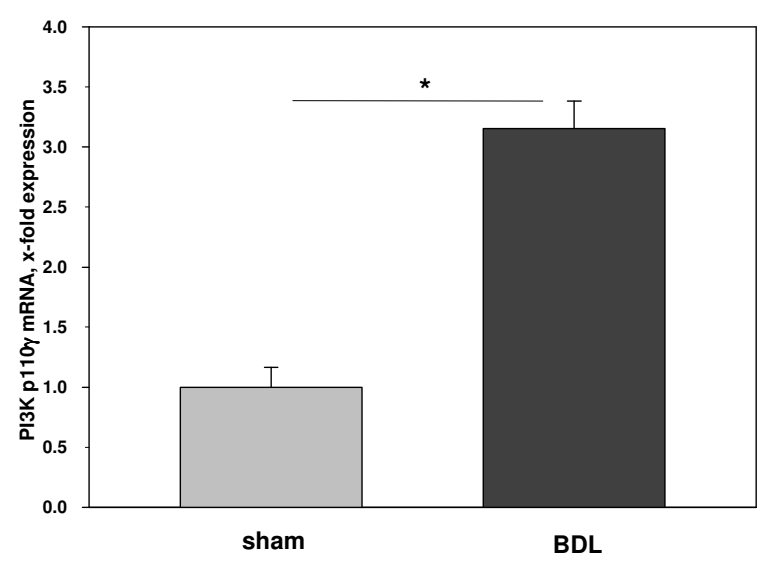

(b)

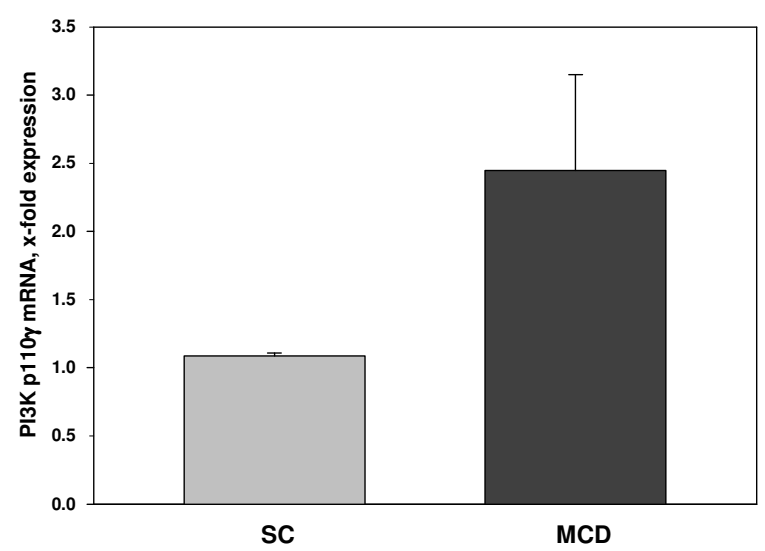

Figure 4a,b: Hepatic mRNA expression of PI3K p110 $\gamma$ in murine liver samples; $\left({ }^{*} p<0.05\right) ; B D L=$ Bile duct ligation, $S C=$ standard chow, $M C D=$ Methionine-choline deficient diet 
(c)

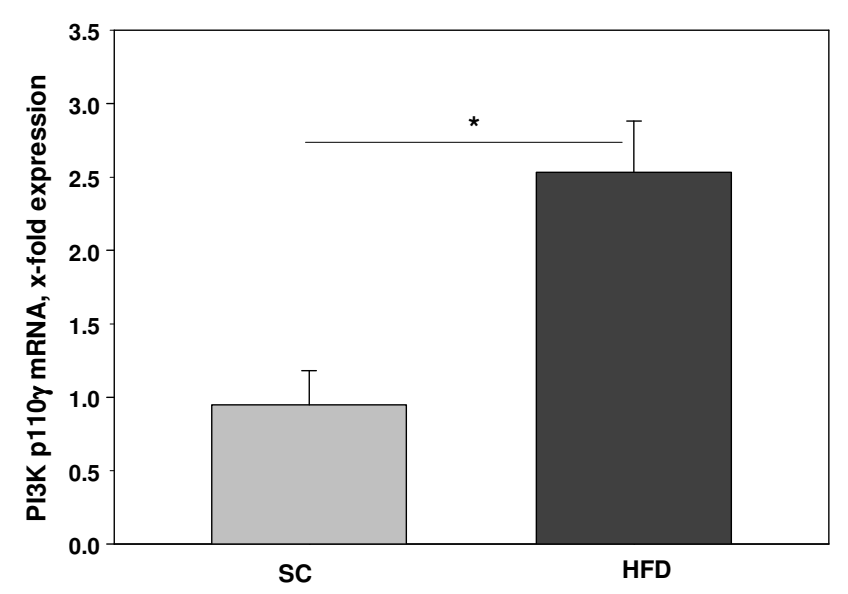

Figure 4c: Hepatic mRNA expression of PI3K p110 $\mathrm{\gamma}$ in murine liver samples; $\left({ }^{*} p<0.05\right)$; $S C=$ standard chow, HFD= High fat diet

Furthermore, we assessed PI3K p110 y mRNA expression in hepatic specimens of patients with hepatic steatosis and NASH (Fig 5a) as well as liver cirrhosis of different origin (Fig $5 b$ ), and detected a marked increase of PI3K p110 $\mathrm{\gamma}$ RNA expression accordingly.

(a)

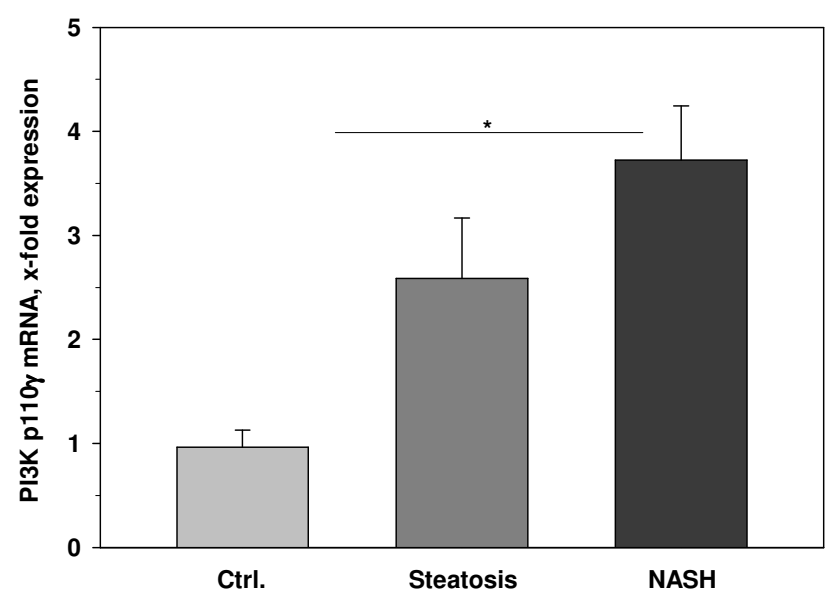

(b)

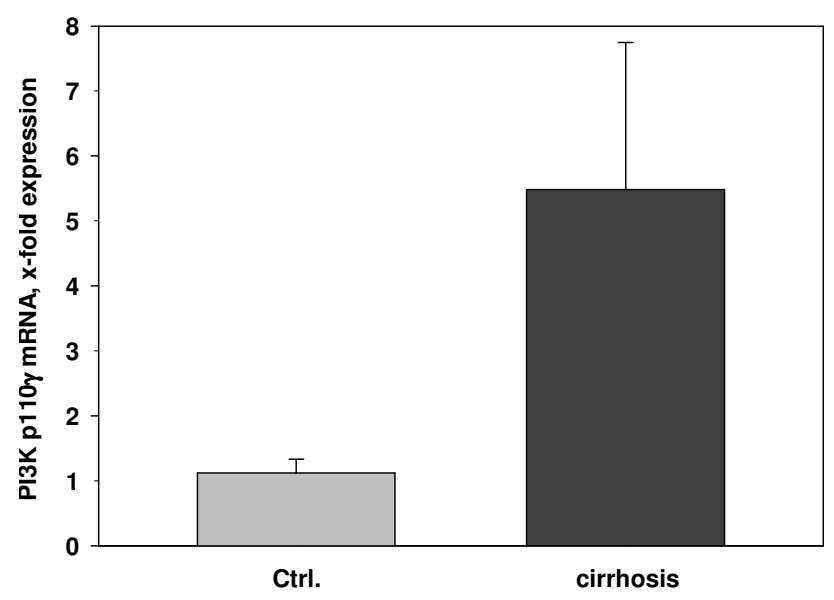

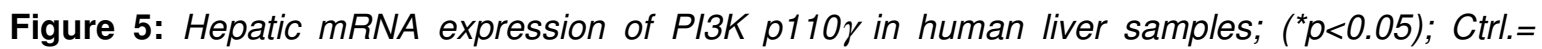
Control 


\section{III.2. Assessment of PI3K p110 $\gamma$ deficient mice vs. wild- type in the bile duct ligation model}

To get an insight into the role of PI3K p110 $\gamma$ in chronic liver disease, we applied the BDL model to PI3K p110 $\gamma$ deficient mice. While a complete knockout of PI3K leads to a lethal phenotype in mice, as does a complete disruption of $p 110 \alpha$ or p110 (Gunzl and Schabbauer, 2008), mice lacking the catalytic subunit p110 $\gamma$ show a normal phenotype with slight deficiencies in T-cell development and activation as well as impaired thymocyte development and reduced macrophage, dendritic- and mast cell migration (Del Prete et al., 2004,Hirsch et al., 2000,Sasaki et al., 2000,Wymann et al., 2003).

\section{III.2.1. Body weight and liver/ body weight ratio}

Throughout the experiment the body weight was regularly measured to assess the general condition of the mice and to get a first impression of differences between the experimental groups. The first step of the assessment of liver injury was the determination of the liver/ body weight ratio, as hepatomegaly is a sign of liver disease.

(a)

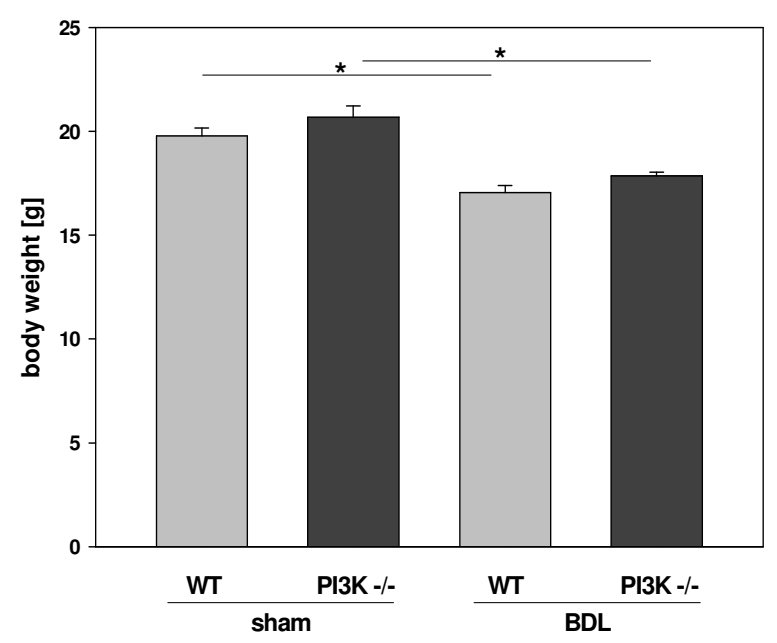

(b)

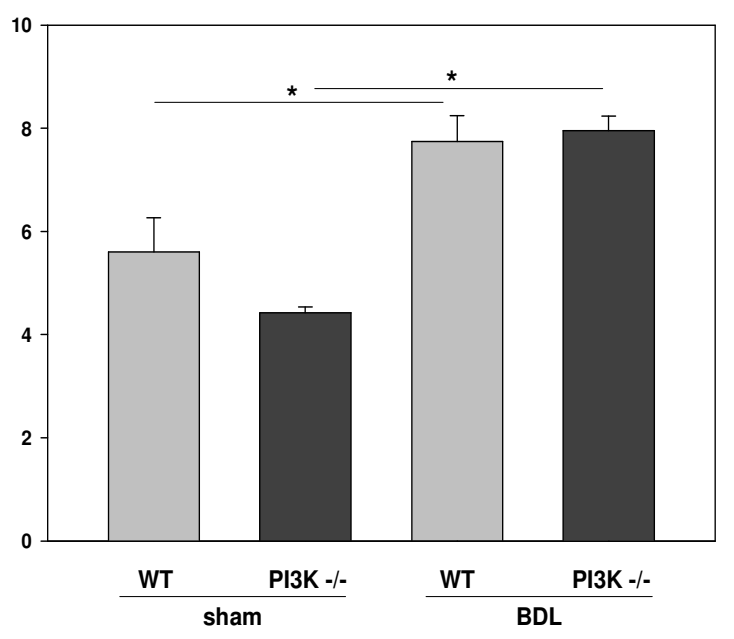

Figure 6: (a) Body weight and (b) liver to body ratio of the sham operated and BDL-mice $\left({ }^{*} p<\right.$

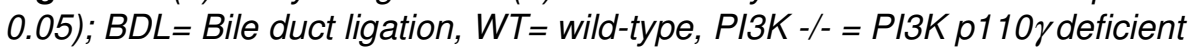


As expected, mice lost weight after surgery, but there was no difference between the wild-type and knockout mice (Fig 6a). The liver/ body weight ratio was significantly higher in the BDL mice, but there was also no difference regarding the genotype of the mice (Fig 6b).

\section{III.2.2. General liver histology (Haematoxylin/Eosin staining)}

BDL ligation induced necrosis and inflammation starting from the bile ducts, whereas sham operated mice showed normal liver histology (Fig 7). There were, however, no remarkable visible differences in the general liver histology of the PI3K p110 $\gamma$ deficient mice with BDL compared to the WT mice.

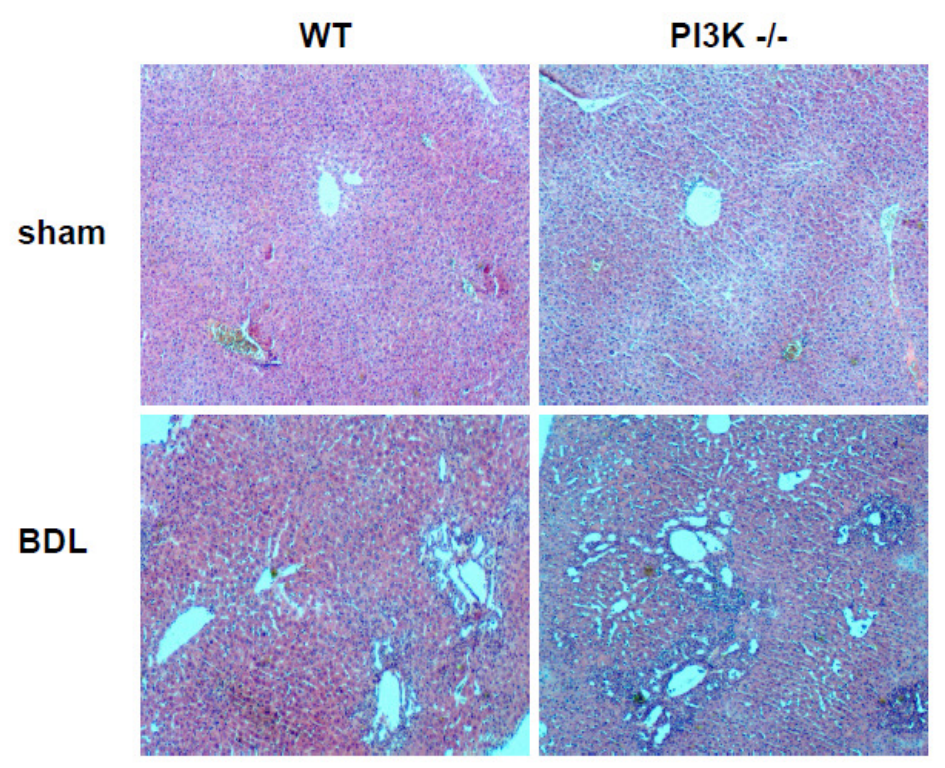

Figure 7: Liver histology; haematoxylin/ eosin stained slides; magnification 40x; BDL= Bile duct

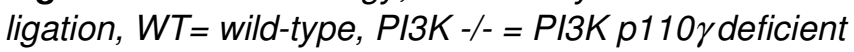




\section{III.2.3. Serum transaminases and levels of bilirubin and alkaline phosphatase}

Serum analysis then revealed significant differences between wild-type and PI3K p110 $\gamma$ deficient mice with BDL. The bile duct ligation led to significant upregulation of transaminases (ALT, AST) in both groups, but the PI3K p110 $\gamma$ deficient mice showed significantly lower transaminase levels (Fig $8 a-b$ ). This was the first sign that the genotype was affecting the degree of liver injury in this model. PI3K p110 deficient mice seemed to be protected against enhanced liver injury compared to control mice.

(a)

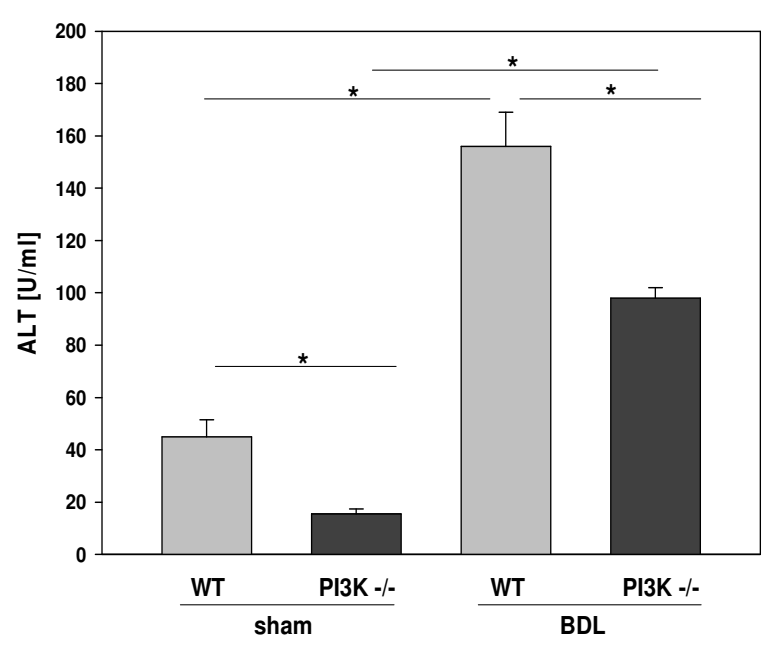

(c)

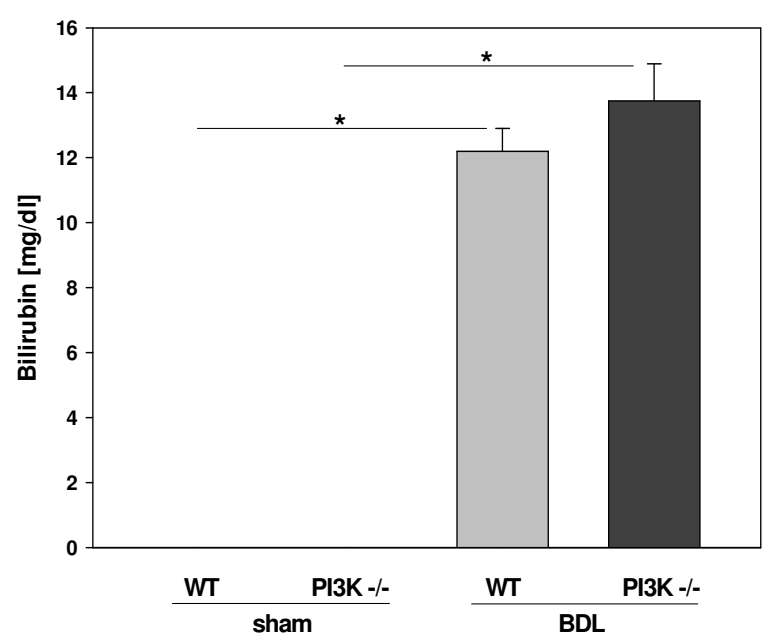

(b)

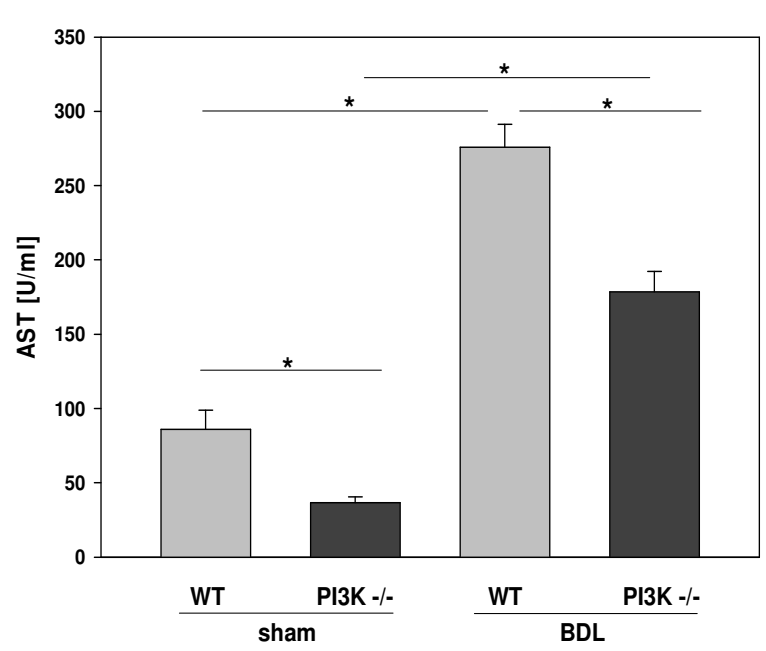

(d)

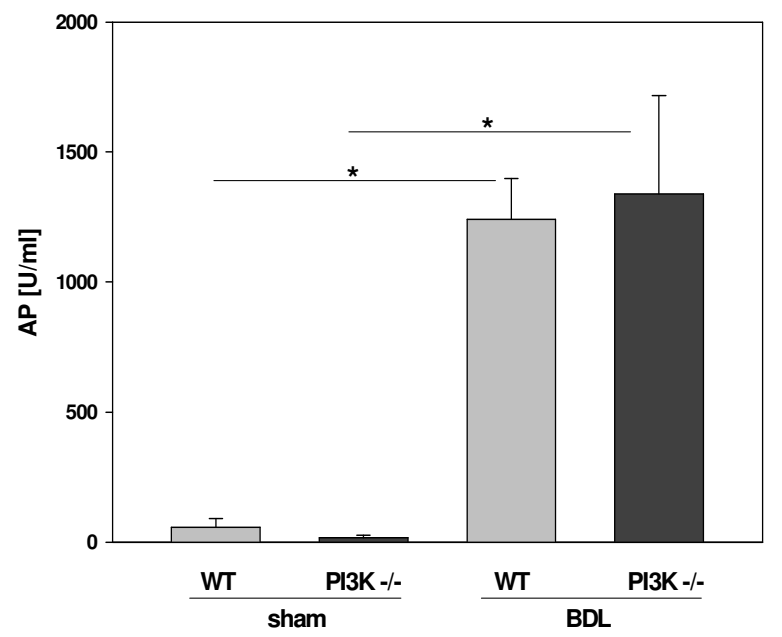

Figure 8: (a-b)Concentration of serum transaminases,levels of (c) bilirubin and (d) $A P ;\left({ }^{*} p<0.05\right)$; $B D L=$ Bile duct ligation, $W T=$ wild-type, $P I 3 K-/-=$ PI3K p110 r deficient 
Bilirubin (total) an levels of alkaline phosphatase (AP) were also markedly increased in BDL mice compared to controls, but no differences between WT and PI3K p110 $\gamma$ deficient mice could be observed (Fig 8c-d), indicating that the underlying liver damaging insult, i.e. cholestasis, was equally effective in both groups.

\section{III.2.4. mRNA expression of markers of hepatic inflammation}

Next, hepatic inflammation was assessed by quantitative PCR. As described (Ramm et al., 2009) BDL lead to significant induction of the expression of the chemokine MCP-1 but there was no significant difference between WT and PI3K p110 $\gamma$ deficient mice (Fig 9a). Furthermore, expression of TNF, a cytokine known to play a crucial role in hepatic inflammation in response to chronic injury, was significantly increased in mice with BDL. Interestingly, mRNA levels of TNF were significantly higher in PI3K $1110 \gamma$ deficient mice with BDL compared to controls (Fig 9b).

(a)

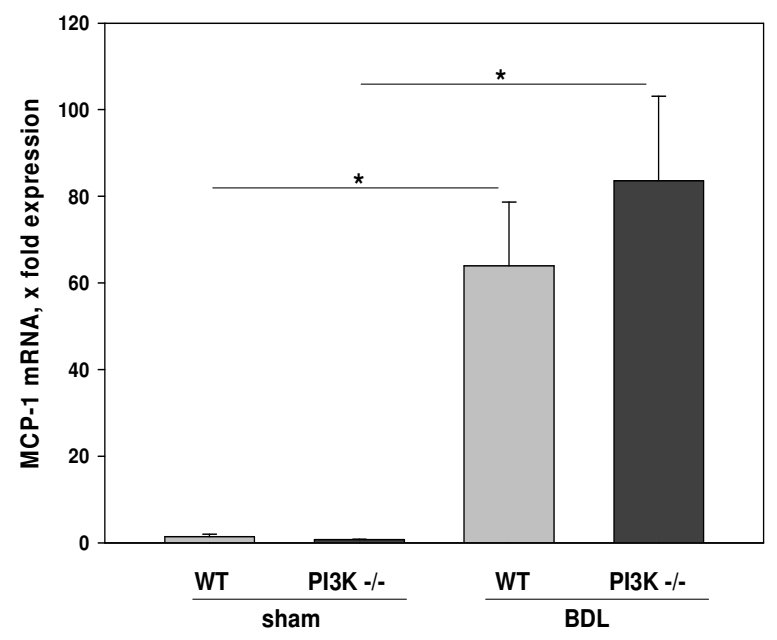

(b)

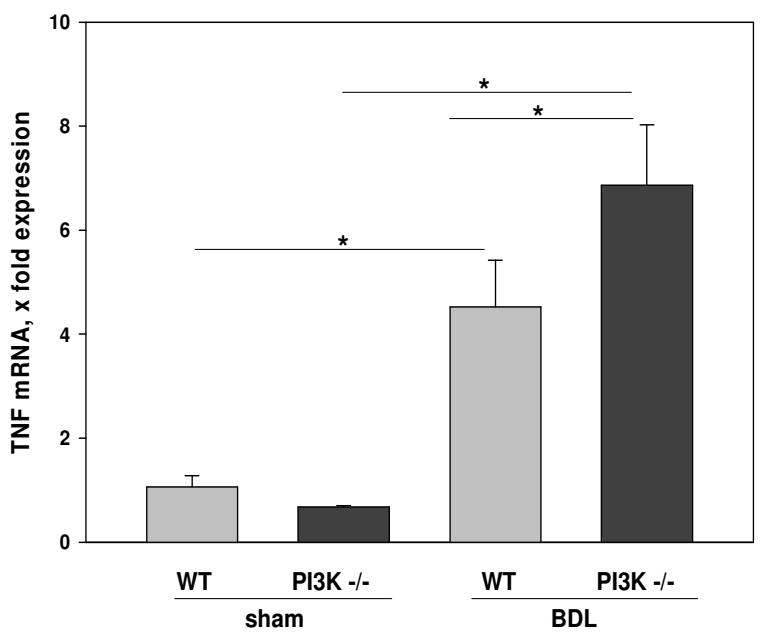

Figure 9: Hepatic mRNA expression of (a) MCP-1 and (b) TNF; ( $\left.{ }^{*} p<0.05\right) ; B D L=$ Bile duct ligation,

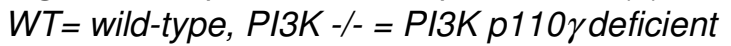




\section{III.2.5. Expression of markers of HSC activation and hepatic fibrosis}

III.2.5.1. mRNA expression of markers of HSC activation and hepatic fibrosis

Expression of profibrogenic markers was then assessed by quantitative PCR. The amount of RNA was normalized to the control group (WT/sham) presented as $\mathrm{x}$ fold expression of the control (set 1). Collagen mRNA levels were lower in PI3K p110 $\gamma$ knockout mice compared to WT controls (Fig 10a). Transforming growth factor beta (TGF $\beta$ ) is known to be one of the most potent profibrogenic cytokines (Poli, 2000). Plasminogen activator inhibitor -1 (Pai-1) mainly regulates fibrinolysis by inhibiting plasminogen activator, but it was shown in several animal models that Pai-1 also contributes to hepatic fibrosis while Pai-1 deficiency protects against ECM accumulation (Bergheim et al., 2006,Wang et al., 2007,Zhang et al., 1999). Both Pai1 mRNA and TGF beta mRNA levels were significantly increased in BDL mice compared to WT mice, but notably significantly lower in PI3K p110 $\gamma$ deficient mice (Fig 10b-c).

(a)

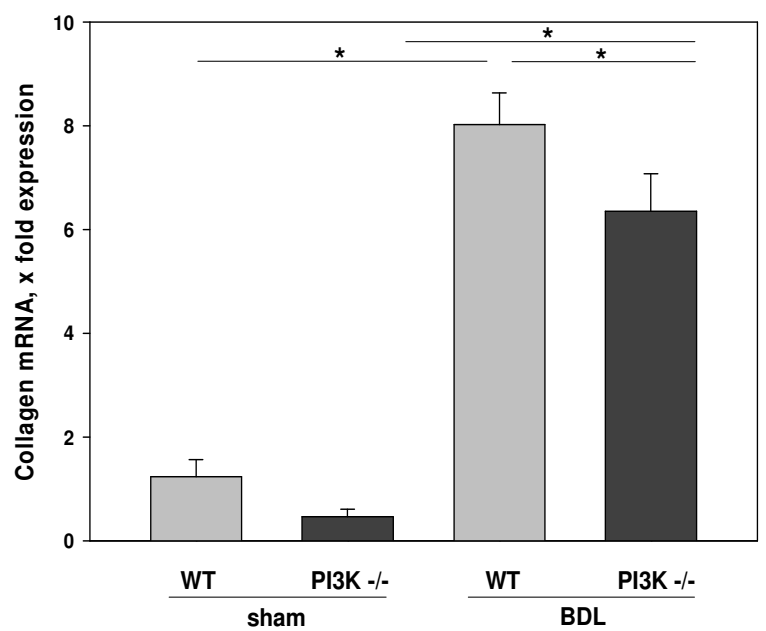

(b)

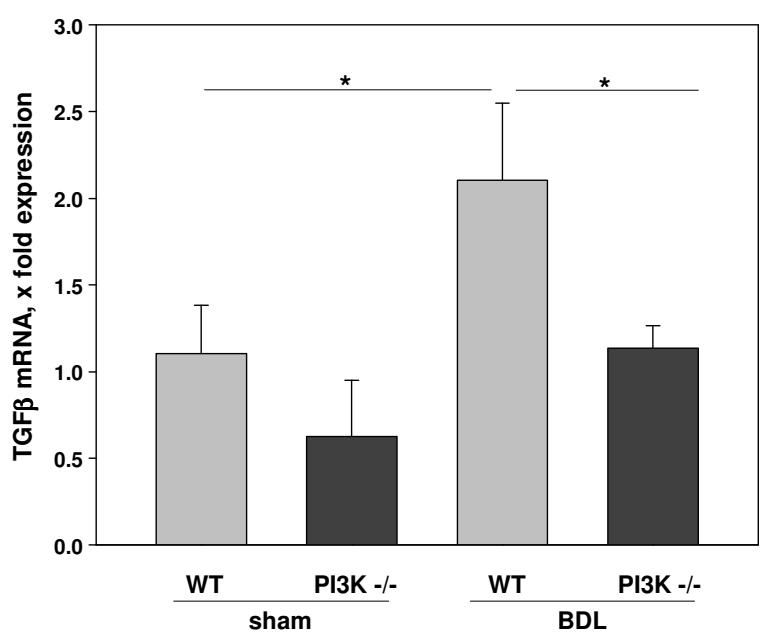

Figure 10a-b: Hepatic mRNA expression of (a) Collagen and (b) TGF $\beta ;\left({ }^{*} p<0.05\right) ; B D L=$ Bile duct ligation, $W T=$ wild-type, $P I 3 K-/-=P I 3 K$ p110 $\gamma$ deficient 
(c)

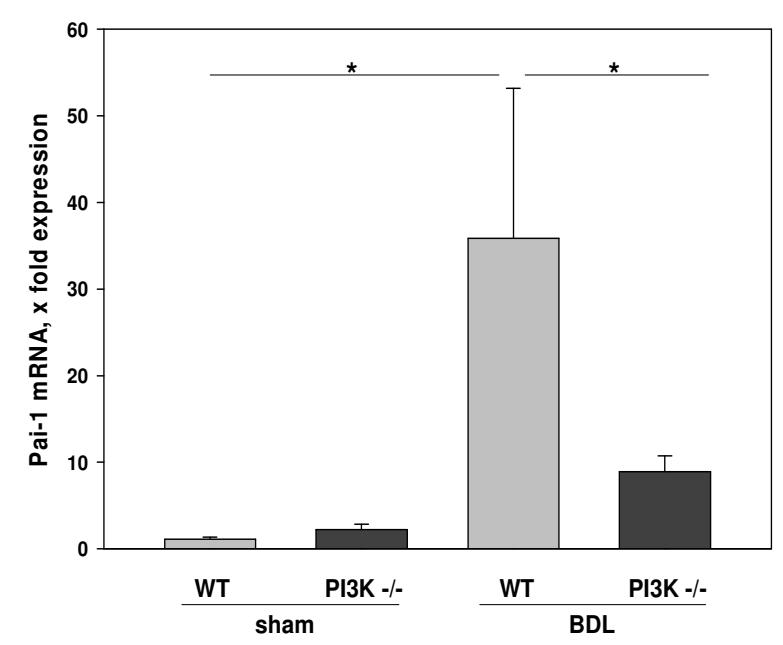

Figure 10c: hepatic mRNA expression of (c) Pai-1; $\left({ }^{*} p<0.05\right) ; B D L=$ Bile duct ligation, $W T=$ wildtype, PI3K - = PI3K p110 r deficient

\section{III.2.5.2. Protein expression of Collagen I}

The level of protein expression of collagen could be demonstrated by Western blot analysis (Fig 11). Only for the WT/BDL group a band for collagen could be made visible by staining with a specific antibody.

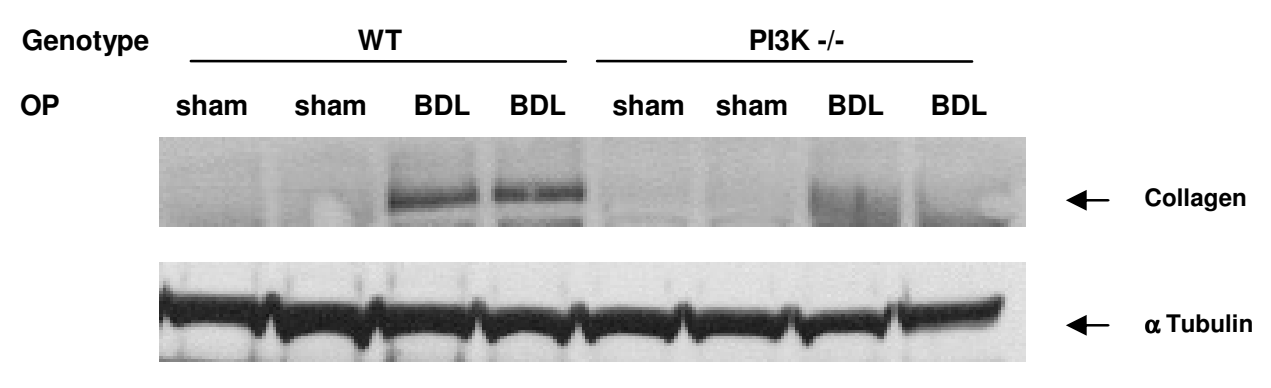

Figure 11: Western blot; upper lane Collagen I, lower lane $\alpha$ Tubulin (housekeeper); BDL= Bile duct ligation, $W T=$ wild-type, $P I 3 K-/-=$ PI3K p110 $\gamma$ deficient 


\section{III.2.5.3. Histological evaluation of fibrosis and HSC activation}

ECM-staining (Sirius red) confirmed marked hepatic fibrosis in the WT mice while only minimal ECM deposition was visible in PI3K p110 $\gamma$ deficient mice with BDL (Fig 12). Quantification of the Sirius red staining confirmed statistically significant differences.
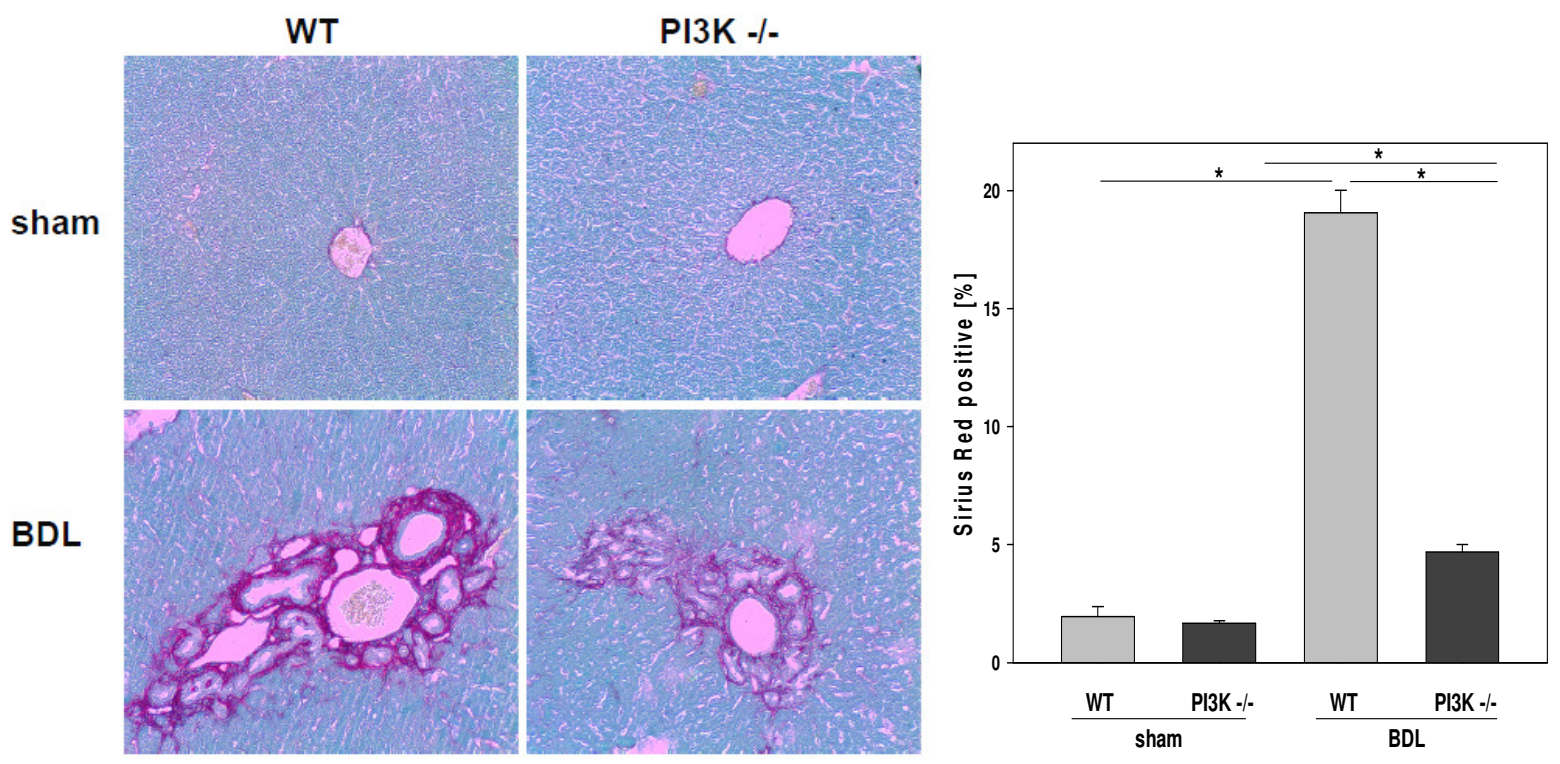

Figure 12: Liver histology; Sirius red/ Fast Green stained slides; magnification 100x; Quantification of Sirius red-positive area [\%]; ( $\left.{ }^{*} \mathrm{p}<0.05\right) ; B D L=$ Bile duct ligation, $W T=$ wild-type, PI3K -/- = PI3K p110rdeficient

In line with these findings, immunohistochemistry revealed that the PI3K p110 deficient mice expressed virtually no hepatic alpha smooth muscle actin ( $\alpha$ SMA) (Fig 13), while WT mice exhibited a significant hepatic $\alpha$ SMA immunosignal. This demonstrated that hepatic stellate cells were significantly less activated by the bile duct ligation when PI3K p110 $\gamma$ was missing. 

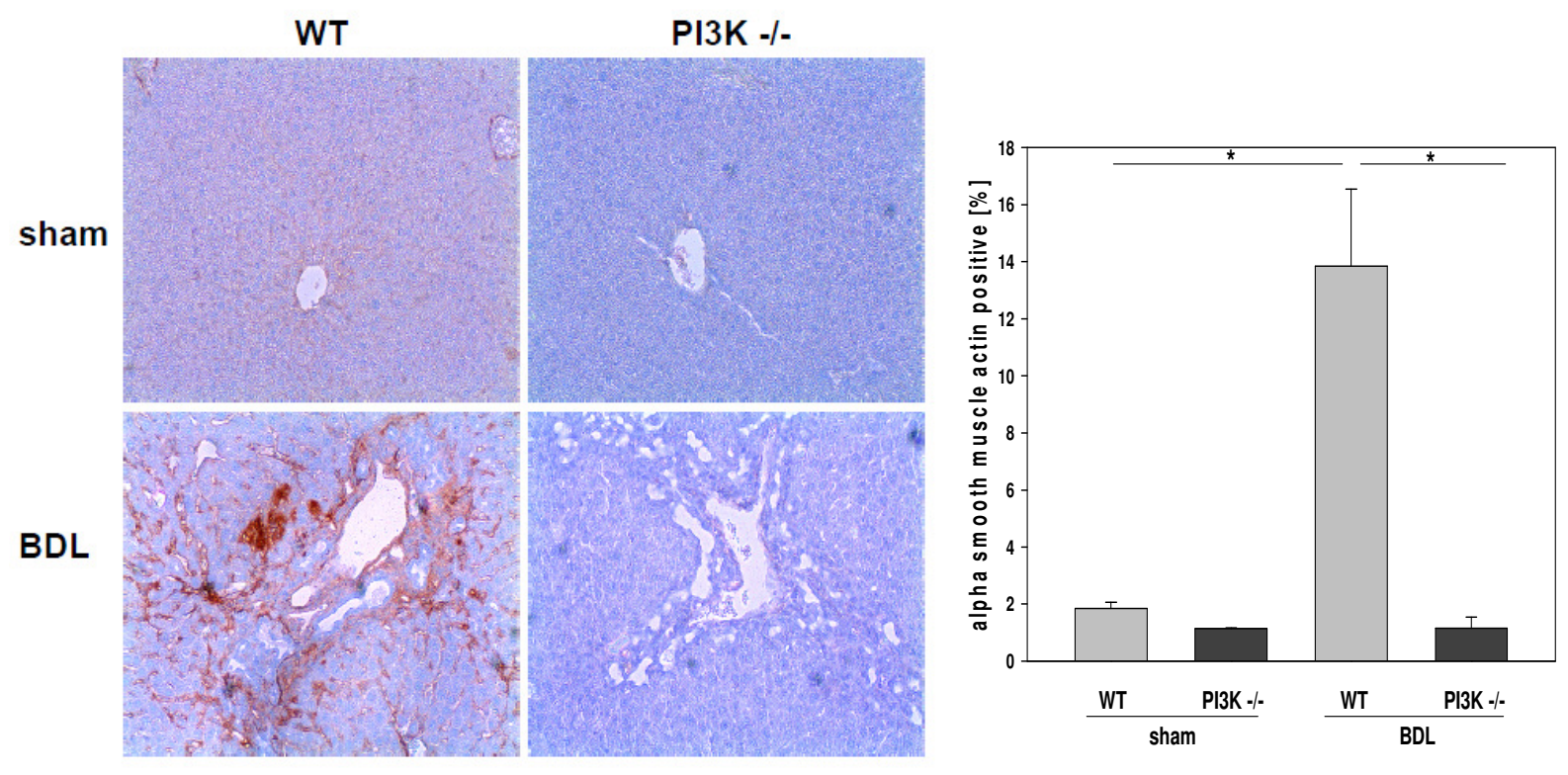

Figure 13: Liver histology; alpha smooth muscle actin stained slides; magnification 100x; Quantification of $\alpha S M A-$ positive area [\%]; ( $\left.{ }^{*} p<0.05\right) ; B D L=$ Bile duct ligation, $W T=$ wild-type, PI3K /- = PI3K p110 rdeficient

In summary, liver injury assessed by serum transaminases was clearly diminished in PI3K p110 $\gamma$ deficient mice after BDL as was hepatic fibrosis shown by histology, quantitative PCR and collagen western blot. Immunohistochemistry for $\alpha \mathrm{SMA}$ showed that the activation of hepatic stellate cells was virtually blocked by PI3K $\mathrm{p} 110 \gamma$ deficiency. Taken together, we demonstrated that PI3K p110 $\gamma$ deficiency strikingly protects against hepatic fibrosis in the BDL model despite minimal or even contrary effects on hepatic inflammation. 


\section{III.3. Assessment of PI3K p110 $\gamma$ deficient mice vs. wild- type in a dietary NASH model}

We sought to confirm the results from the BDL model in a second model of hepatic injury, a dietary NASH-model, which had recently been shown to induce the pathology of NASH with HSC activation as seen in patients with NASH (Matsuzawa et al., 2007) and had already been used by our group (Dorn et al., 2010a,Kirovski et al., 2010).

Therefore, we fed either a NASH-inducing high fat diet (HFD) or standard chow

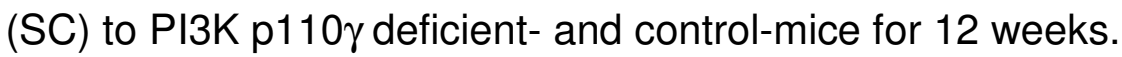

\section{III.3.1. Body weight and liver/ body weight ratio}

As expected mice fed with the HFD gained slightly more weight than mice on standard chow, but after 12 weeks feeding neither in the control group (WT=21.3 g $+/-0.7 \mathrm{~g}$ vs. $\mathrm{PI3K}$ p110 $\gamma$ deficient $=21.4 \mathrm{~g}+/-0.3 \mathrm{~g})$ nor in the HFD group $(\mathrm{WT}=22.8$ $\mathrm{g}+/-0.4 \mathrm{~g}$ vs. PI3K $110 \gamma$ deficient $=22.5 \mathrm{~g}+/-0.7 \mathrm{~g}$ ) differences could observed between WT and PI3K p110 $\gamma$ deficient mice. Liver to body weight ratio was significantly increased in both HFD groups, with PI3K $1110 \gamma$ deficient mice exhibiting an even higher relative liver weight although this difference did not reach statistical significance (Fig 14).

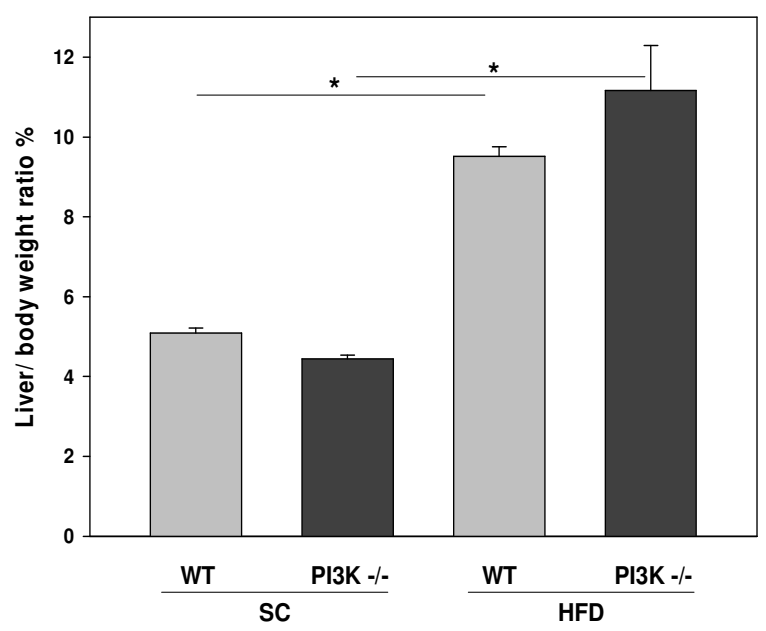

Figure 14: Liver to body ratio; ( $\left.{ }^{*} p<0.05\right)$; $S C=$ standard chow, HFD= high fat diet, $W T=$ wild-type,

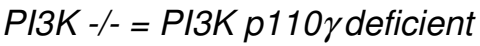




\section{III.3.2. Serum Transaminases and LDH}

Next, serum parameters were examined to evaluate the degree of liver injury. Like in the BDL model, the genotype was affecting the severity of liver injury, but in contrast to the BDL the high fat diet lead to higher levels of transaminases (ALT, AST) in PI3K p110 $\gamma$ deficient mice (Fig 15a-b). Thus, lack of PI3K p110 $\gamma$ did not protect against liver injury in the NASH model.

(a)

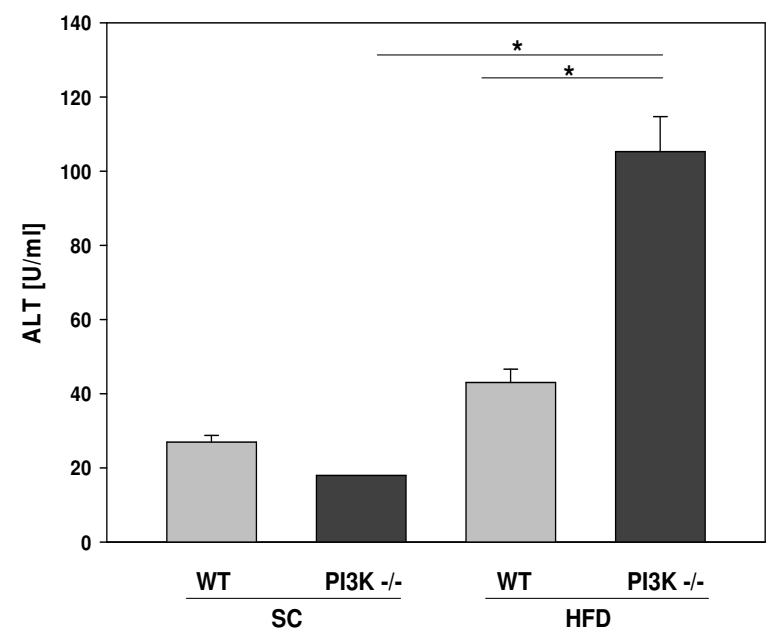

(b)

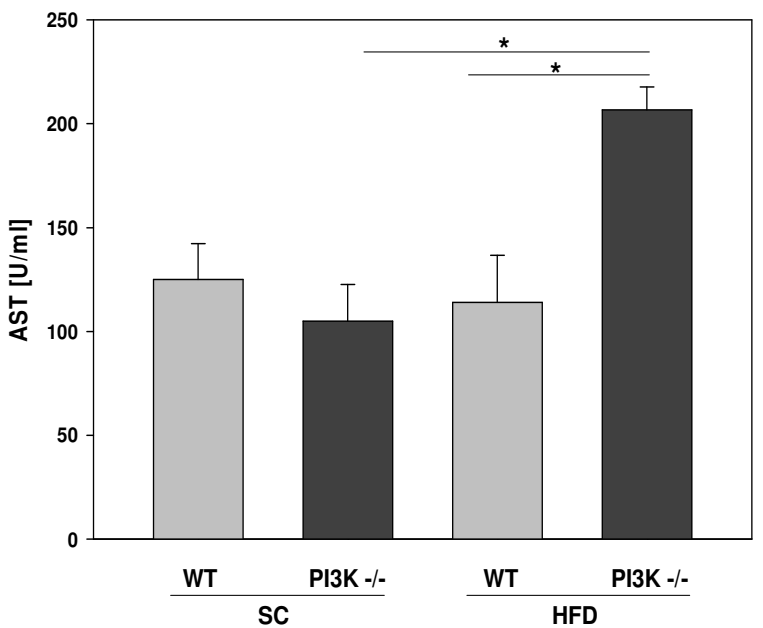

Figure 15: (a-b) Concentration of serum transaminases; $\left({ }^{*} p<0.05\right) ; S C=$ standard chow, HFD= high fat diet, $W T=$ wild-type, $P I 3 \mathrm{~K}-/-=$ PI3K p110 deficient

\section{III.3.3. mRNA expression of markers of hepatic inflammation}

Next, hepatic inflammation was assessed by quantitative PCR. Expression of MCP-1 and TNF, which also play a crucial role in the progression of NAFLD/NASH, was significantly elevated in HFD-fed mice and levels were significantly higher in PI3K p110 $\gamma$ mice compared to WT mice (Fig 16a-b), confirming the fact, that liver injury was enhanced in these mice. 
(a)

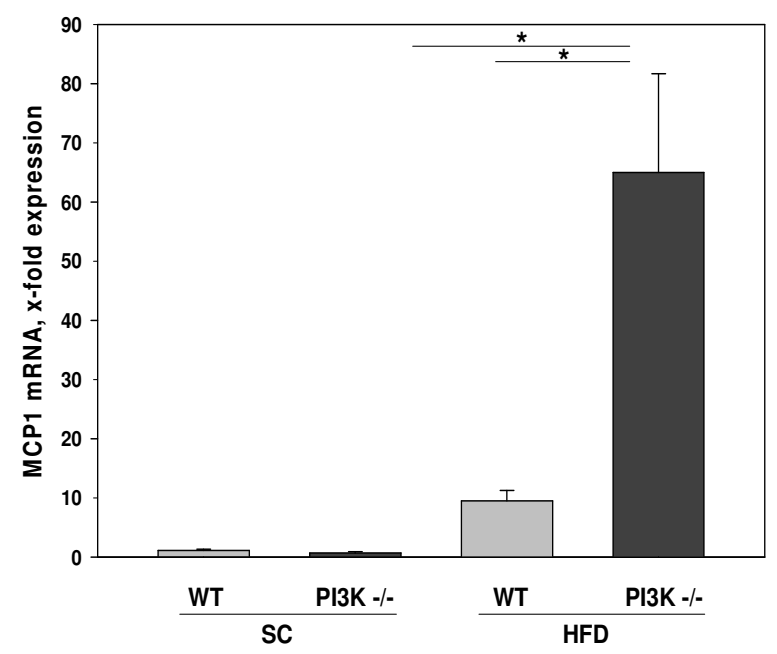

(b)

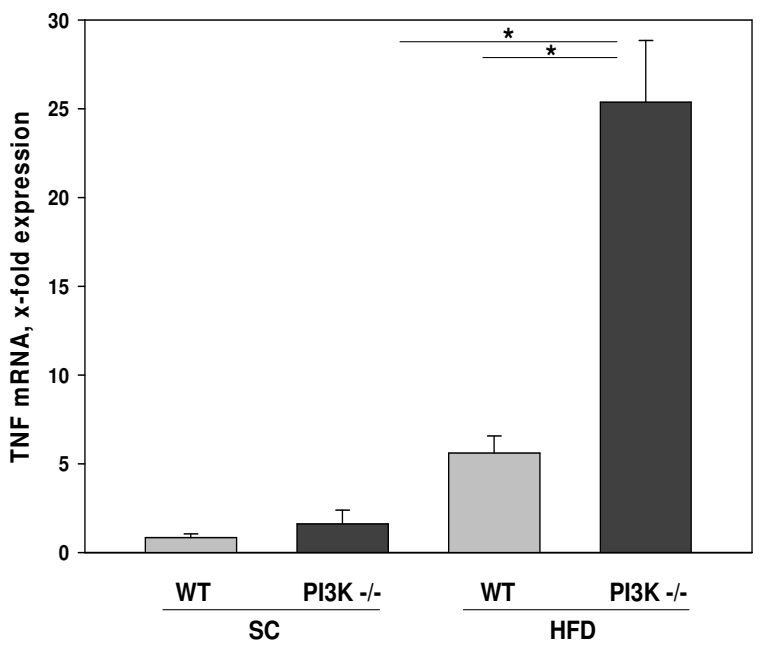

Figure 16: Hepatic mRNA expression of (a) MCP-1 and (b) TNF; $\left({ }^{*} p<0.05\right) ; S C=$ standard chow, $H F D=$ high fat diet, $W T=$ wild-type, $P I 3 K-/-=P I 3 K$ p110 r deficient

\section{III.3.4. Expression of markers for HSC activation and fibrosis}

\section{III.3.4.1. mRNA expression of profibrogenic markers}

Expression of profibrogenic markers was assessed by quantitative PCR. The amount of RNA was normalized to the control group (WT/SC) presented as $x$-fold expression of the control (set 1). The results on mRNA level overall supported the observation that $\mathrm{PI} 3 \mathrm{~K}$ p110 $\gamma$ deficient mice were not protected from liver fibrosis in the NASH model. Collagen mRNA expression was significantly elevated in PI3K p110 $\gamma$ deficient mice compared to wild-type mice, so was the expression of TGF $\beta$ and Pai-1 (Fig 17a-c). 
(a)

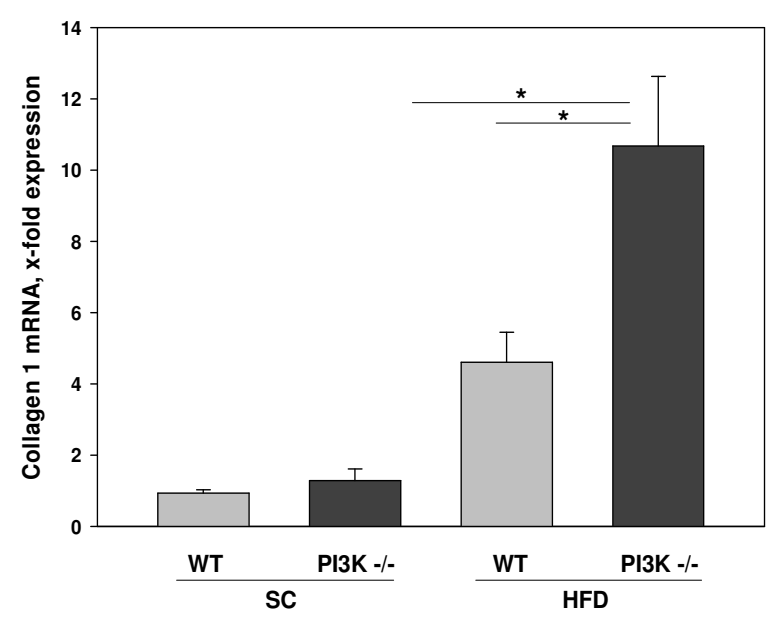

(c)

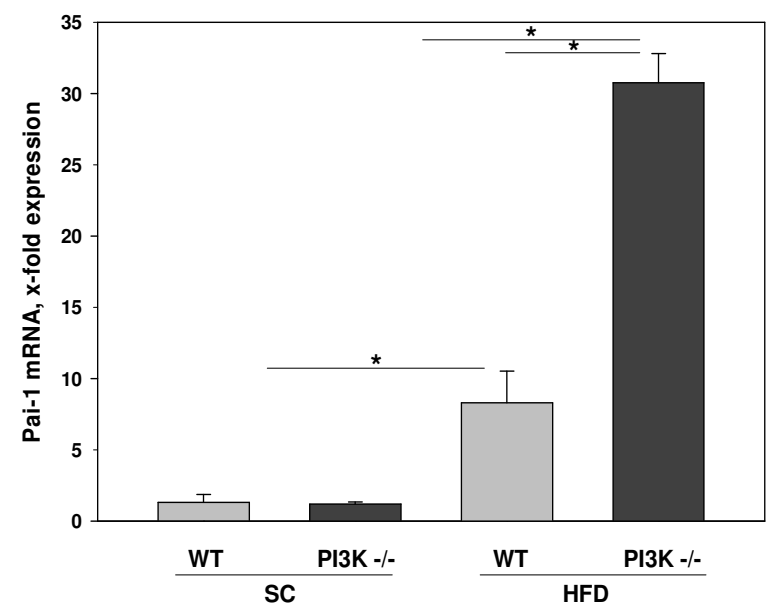

(c) (b)

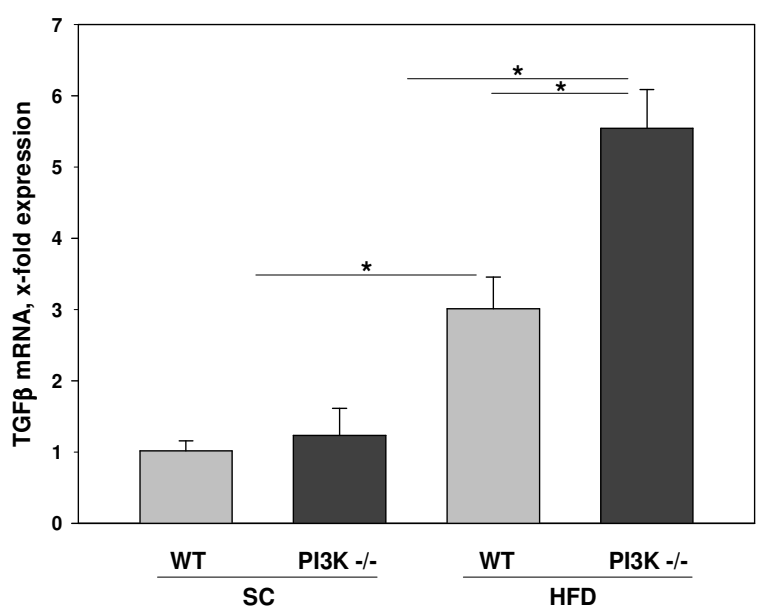

Figure 17: Hepatic mRNA expression of (a) Collagen, (b) TGF $\beta$ and (c) Pai-1; ( ${ }^{*} p<0.05$ ); $S C=$ standard chow, HFD = high fat diet, $W T=$ wild-type, $P I 3 K-/-=P I 3 K$ p110 rdeficient

\section{III.3.4.2. Protein expression of collagen}

A Western blot for collagen confirmed the previous observations. Matching the histology a band for collagen was only visible in the PI3K p110 $\gamma$ deficient mice on the HFD (Fig 18). 


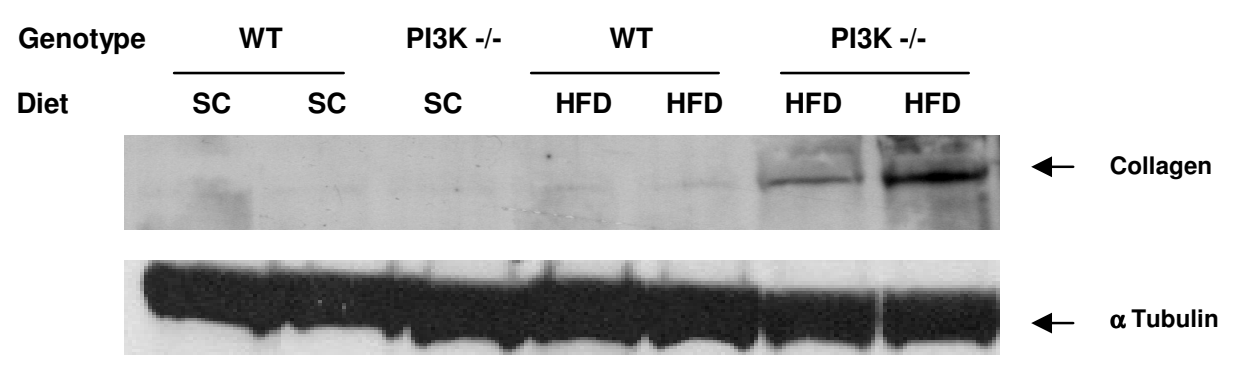

Figure 18: Western blot; upper lane Collagen 1, lower lane $\alpha$ Tubulin (housekeeper); SC=standard

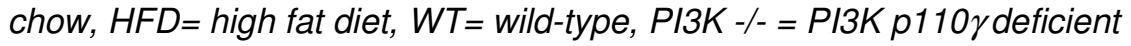

\section{III.3.4.3. Histological evaluation of fibrosis and HSC activation}

A collagen stain (Sirius red) revealed very clear and highly significant differences between the experimental groups. PI3K p110 $\gamma$ deficient mice with NASH showed visibly higher hepatic ECM deposition compared to the WT mice (Fig 19). The staining was quantified and differences were statistically significant.
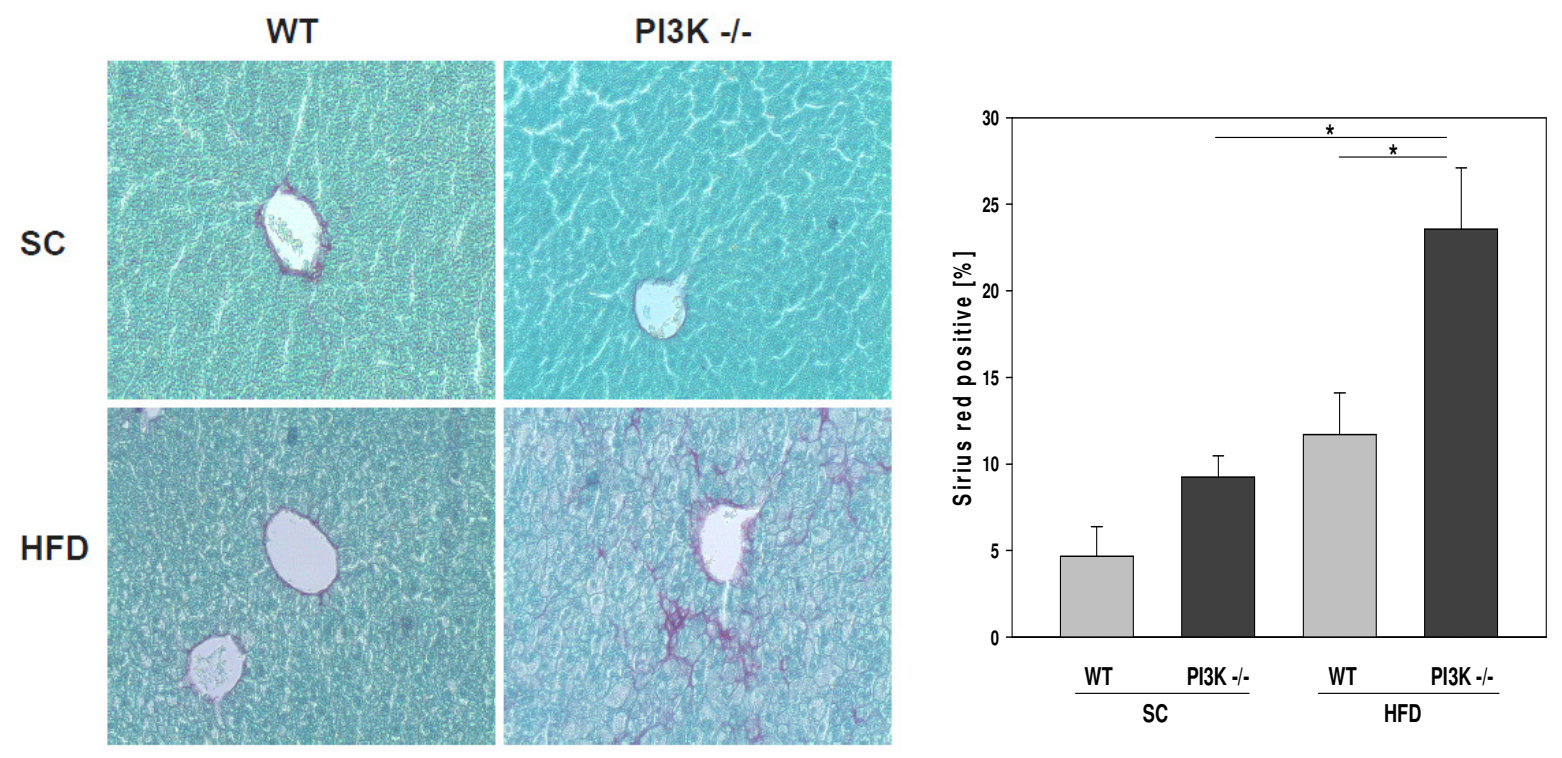

Figure 19: Sirius red/ Fast Green staining; magnification 100x; Quantification of Sirius red- positive area [\%]; $\left({ }^{*} p<0.05\right) ; S C=$ standard chow, HFD= high fat diet, $W T=$ wild-type, PI3K $-/-=P I 3 K$ p110rdeficient 
Immunohistochemistry for $\alpha$ SMA confirmed the previous results. Significantly more $\alpha$ SMA positive cells could be detected by immunohistochemistry in the livers of PI3K p110 $\gamma$ deficient mice fed the HFD compared to WT mice (Fig 20). Virtually no immunosignal could be detected in both WT and PI3K p110 $\gamma$ deficient mice fed the standard chow. The staining was again quantified.
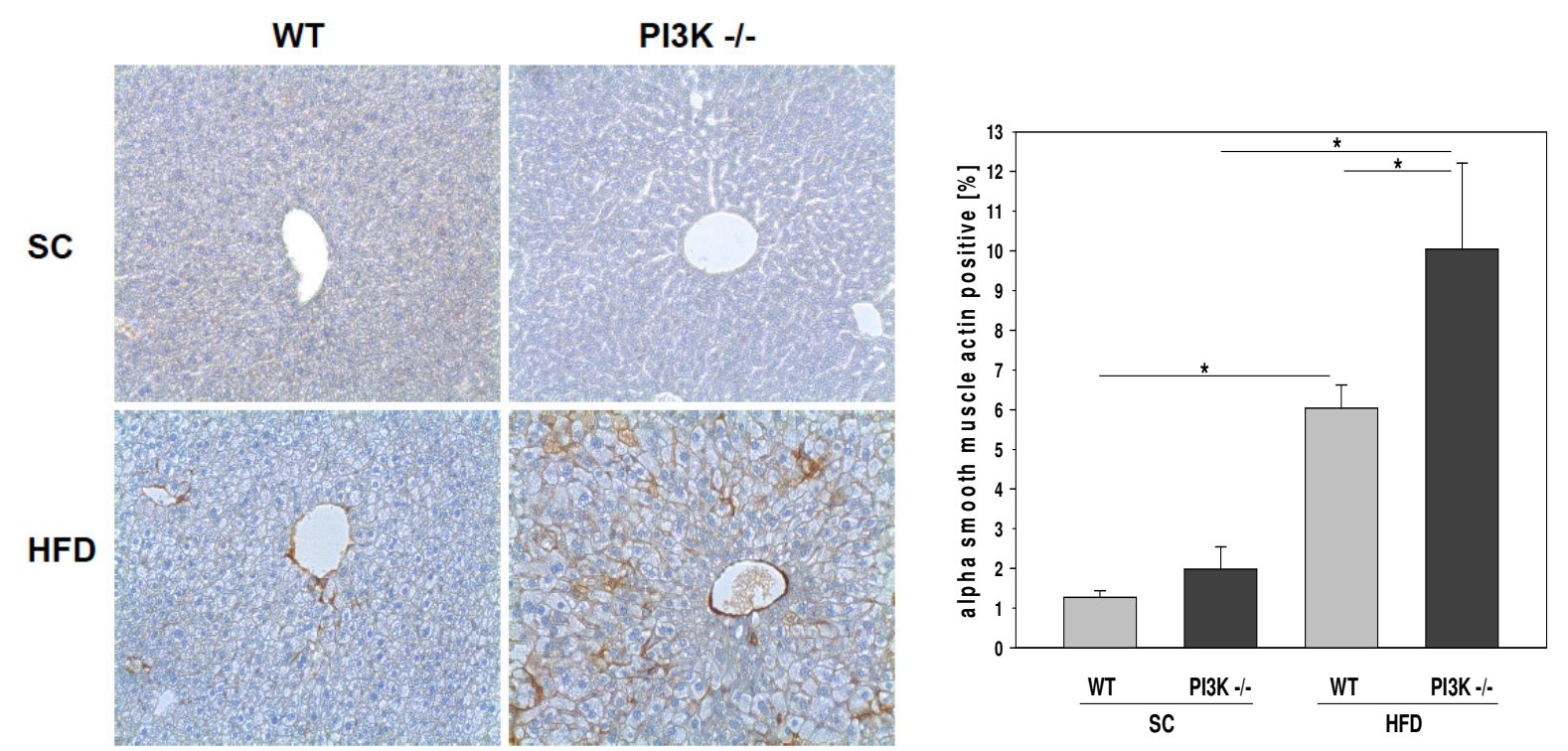

Figure 20: Immunohistochemistry for alpha smooth muscle actin; magnification 100x; Quantification of $\alpha S M A-$ positive area [\%]; $\left.{ }^{*} p<0.05\right)$; $S C=$ standard chow, HFD= high fat diet, WT=

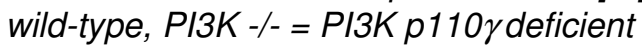

Taken together, histological analysis revealed beginning fibrosis in WT mice receiving the HFD diet. However, these histological features of NASH were significantly more pronounced in the PI3K p110 $\gamma$ deficient mice. Serum analysis showed significantly higher serum transaminases in PI3K p110 $\gamma$ deficient mice with NASH compared to WT. Accordingly, hepatic mRNA expression of proinflammatory and pro-fibrogenic genes was significantly induced in PI3K p110 compared to WT mice with NASH in line with elevated collagen I protein and $\alpha$ smooth muscle actin expression.

In summary and in contrast to the BDL model, in the dietary NASH model hepatic inflammation and fibrosis were markedly enhanced in PI3K p110 $\gamma$ deficient mice compared to WT control animals. 


\section{III.4. Search for mechanisms causing the opposing effects of PI3K p110 $\gamma$ deficiency on hepatic fibrosis in the BDL and NASH model}

\section{III.4.1. Hepatocyte apoptosis}

In search for mechanisms causing the opposing effects of PI3K p110y deficiency on hepatic fibrosis in the BDL and NASH model, we first evaluated hepatic apoptosis.

Hepatocyte apoptosis is mainly triggered by the two death receptor ligands TNF and CD95/Fas ligand (FasL). In NASH activation of the death receptor Fas promotes mitochondrial dysfunction generating reactive oxidative species and apoptosis (Feldstein et al., 2003). Although little is known about the function of individual PI3K subunits regarding their role in hepatocellular apoptosis, it has been shown that the PI3K/Akt pathway has a protective role in Fas-mediated apoptosis via NFkB (Hatano and Brenner, 2001). To examine apoptosis, mRNA expression of CD95 and protein expression (immunohistochemistry) of active caspase 3, which is activated downstream of Fas, were evaluated and a TUNEL staining was performed. It has been described that lipid accumulation leads to an enhanced expression of CD95 on hepatocytes (Wedemeyer et al., 2009). Consistent with this result we observed an upregulation of hepatic CD95 mRNA expression in WT mice fed the HFD (Fig 21a). Both TUNEL and caspase 3 staining revealed significant apoptosis in HFD-fed WT-mice compared to SC-fed controls accordingly (Fig 21b-c). Contrary to what could have been expected there existed virtually no apoptosis in the hepatic tissue of HFD-fed PI3K p110 $\gamma$ deficient mice, and the HFD-induced CD95 mRNA was completely ameliorated in PI3K p110 $\gamma$ deficient mice (Fig 21a-c).

Taken together the differences regarding apoptosis do not seem to be responsible for the differences observed in the BDL and NASH-model regarding the effect of PI3K p110 $\gamma$ deficiency on hepatic fibrosis. 
(a)

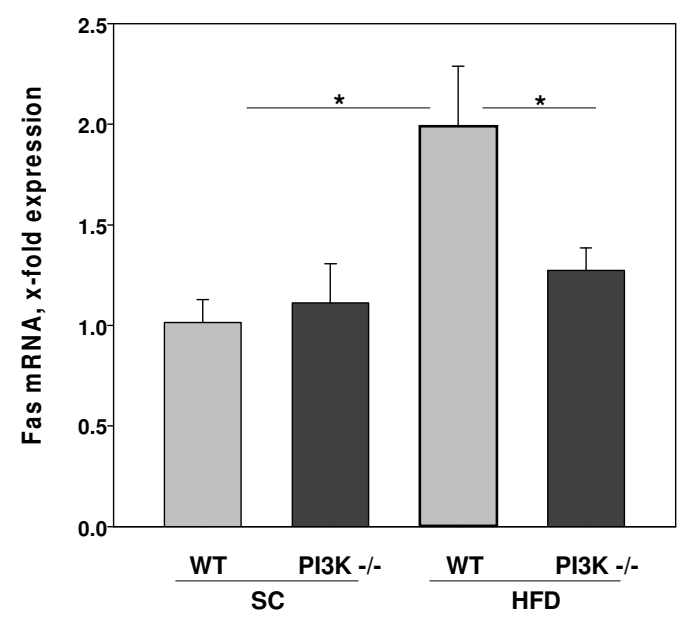

(b)

WT

PI3K -/-

sc

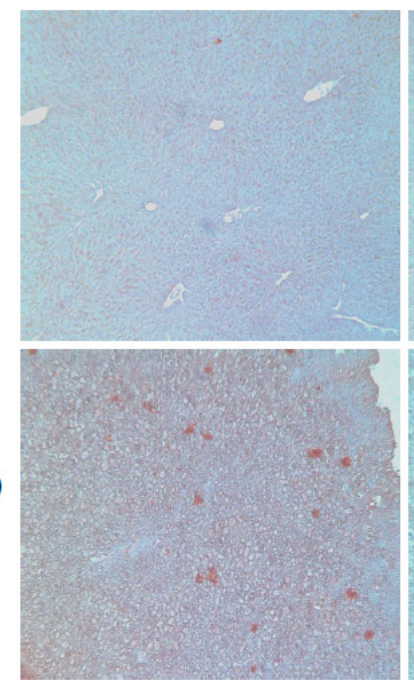

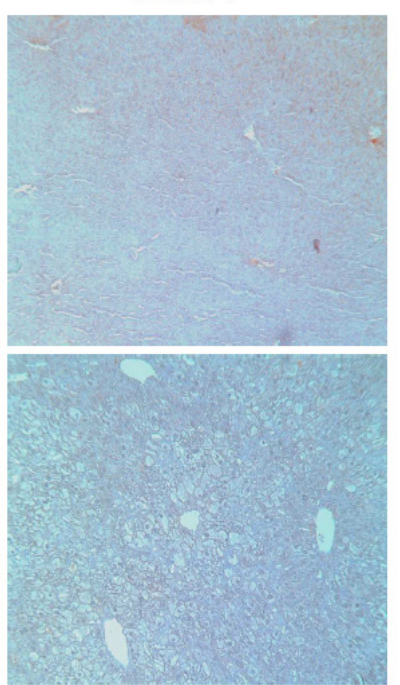

(c)

WT

PI3K -/-

SC
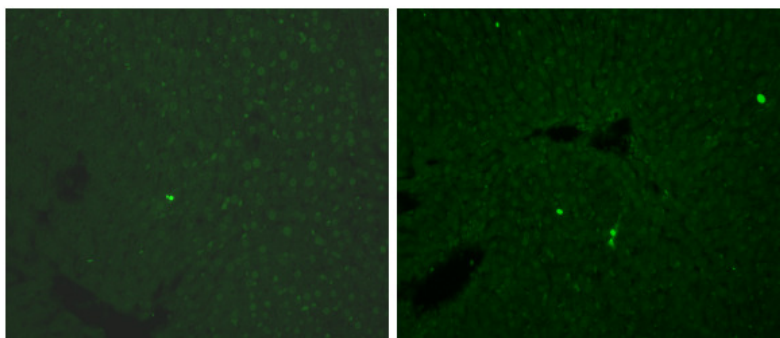

HFD
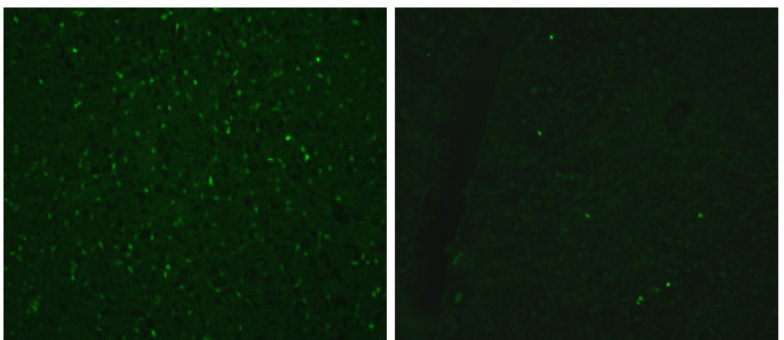

Figure 21: $m R N A$ expression of CD95, immunohistochemistry for active caspase-3 and TUNEL staining; magnification $40 x,\left({ }^{*} p<0.05\right) ; S C=$ standard chow, HFD= high fat diet, WT= wild-type, PI3K $-/-=$ PI3K p110 rdeficient 


\section{III.4.2. Hepatic Steatosis and oxidative stress}

\section{III.4.2.1. Histological evaluation of fatty degeneration}

$\mathrm{NASH}$ is characterized by macrovesicular steatosis and ballooning of hepatocytes (Contos and Sanyal, 2002). Thus, we next analyzed whether this initiating pathophysiological mechanism of NAFLD, i.e. hepatic lipid accumulation, was differently affected by PI3K p110 $\gamma$ deficiency. Already common $\mathrm{H} / \mathrm{E}$ staining revealed significantly enhanced steatosis, i.e. more lipid loaded hepatocytes, in PI3K p110 $\gamma$ deficient mice compared to WT-mice on the HFD (Fig 22). Furthermore, histology of HFD-fed PI3K p110 $\gamma$ deficient livers revealed significant ballooning of hepatocytes, whereas WT mice showed less ballooning. Because lipids, i.e. hepatocellular lipid droplets, are washed out during the fixation procedure of paraffin embedded tissue, they appear as white area in histology. Accordingly, image analysis was performed to quantify $\mathrm{H} / \mathrm{E}$ negative areas and confirm the observation that hepatic steatosis was significantly enhanced in PI3K p110 $\gamma$ deficient livers in response to HFD-feeding compared to WT-animals.
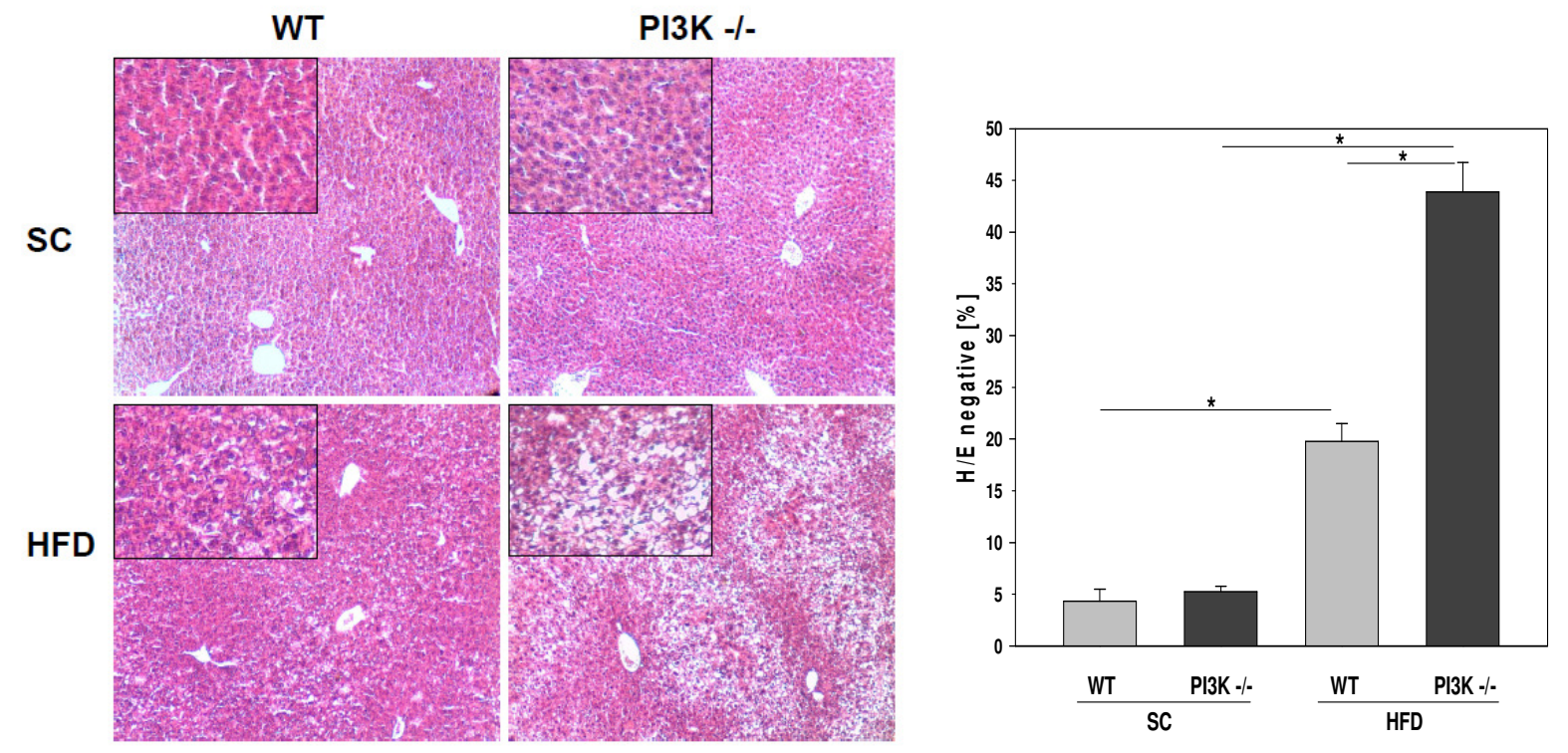

Figure 22: Haematoxylin/eosin stained staining; magnification 40x and 100x respectively (detail); $S C=$ standard chow, HFD = high fat diet, $W T=$ wild-type, $P I 3 K-/-=P I 3 K$ p110 $\gamma$ deficient 
To further substantiate this result a specific fat staining (Sudan III) was done on cryo-sections (Fig 23). This stain confirmed the previous observations, as there were clearly more Sudan III positive cells visible in the PI3K p110 $\gamma$ deficient mice. Furthermore, there appeared bigger lipid droplets in the PI3K p110 $\gamma$ deficient mice.

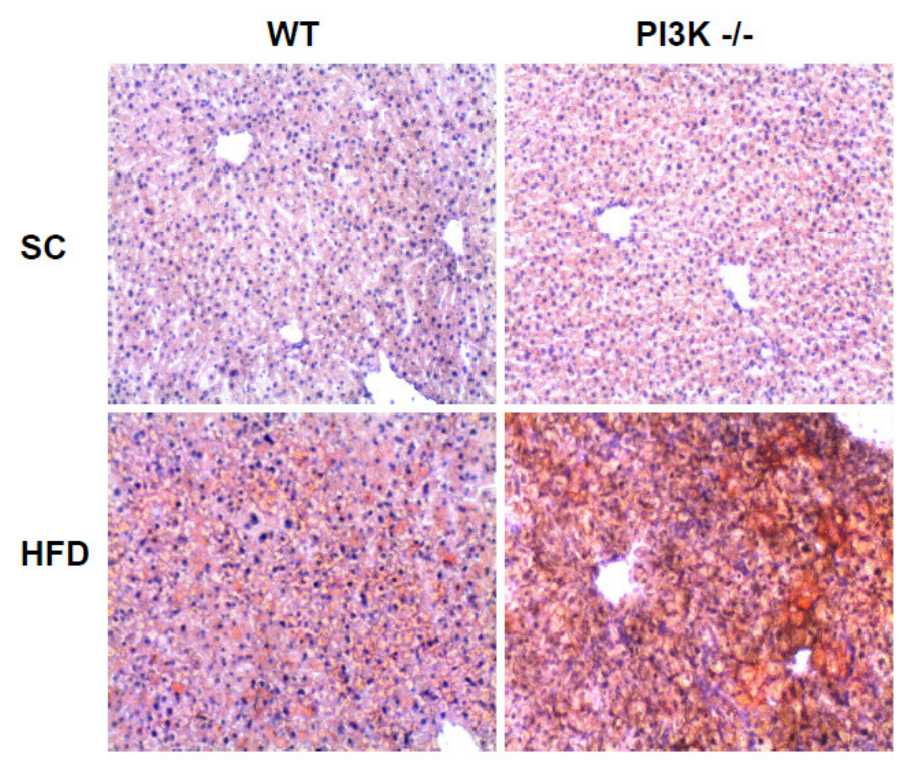

Figure 23: Cryo-sections with staining of lipids (Sudan III), Magnification 100x; SC=standard chow, $H F D=$ high fat diet, $W T=$ wild-type, $P I 3 K-/-=$ PI3K p110 rdeficient

\section{III.4.2.2. Intra-hepatic lipid content}

Next, we analyzed hepatic content of free fatty acids (FFA) and triglycerides (TG) in the 4 experimental groups. After 12 weeks HFD-feeding, FFA were only slightly elevated in WT-mice but significantly in PI3K p110 deficient mice (Fig 24a).

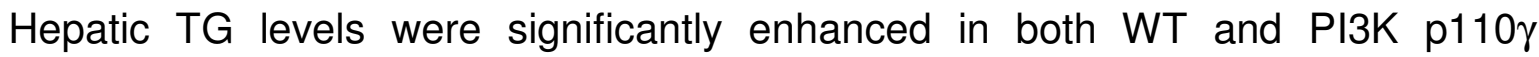
deficient mice, whereas TG levels were even higher in PI3K p110 $\gamma$ deficient mice on HFD although these differences did not reach statistical significance (Fig 24b). In addition, it has to be noted that PI3K p110 $\gamma$ deficient mice had also slightly enhanced hepatic TG levels when fed SC. 
(a)

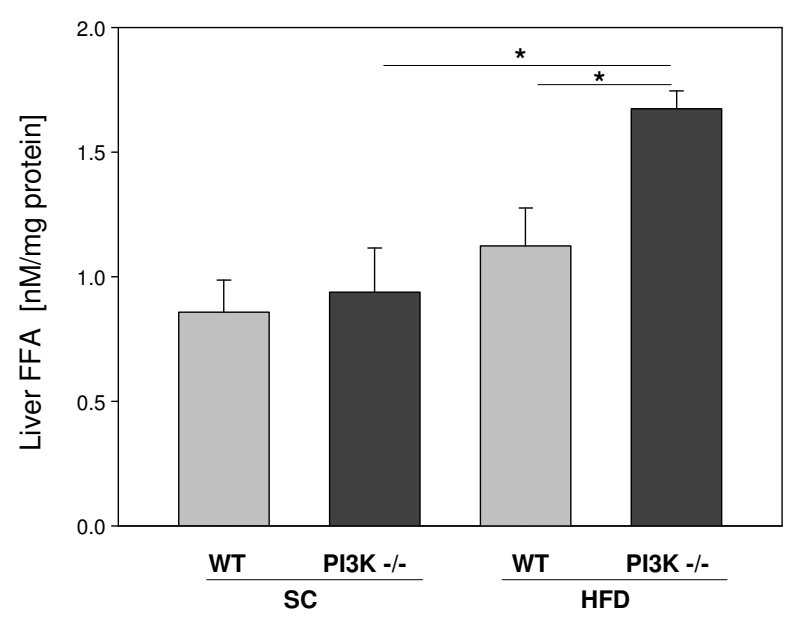

(b)

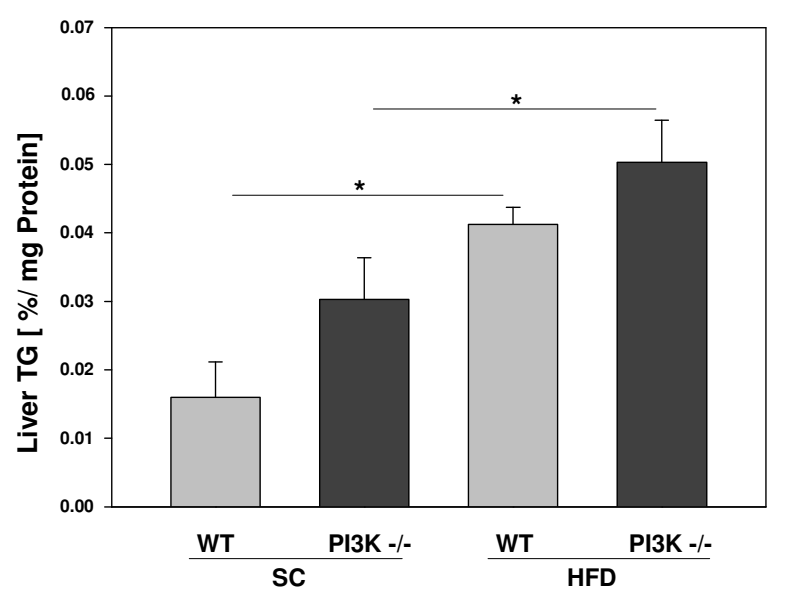

Figure 24: Intra-hepatic free fatty acid and triglyceride levels; ( $\left.{ }^{*} p<0.05\right)$; $S C=$ standard chow, $H F D=$ high fat diet, $W T=$ wild-type, $P I 3 K-/-=$ PI3K p110 rdeficient

\section{III.4.2.3. Oxidative stress}

FFA are known to activate plasma membrane NADPH oxidases (reviewed by (Schonfeld and Wojtczak, 2008), and this enzyme complex has been implicated in the progression of chronic liver diseases (De Minicis and Brenner, 2007). Actually, the activation of the NADPH-oxidase complex provides a cellular defense mechanism against fungi and bacteria by generation of hydrogen peroxide $\left(\mathrm{H}_{2} \mathrm{O}_{2}\right)$ (Babior, 1999). However, increased levels of oxidative stress are also evident in a variety of experimental diet induced metabolic dysfunctions (Diniz et al., 2006,Matsuzawa-Nagata et al., 2008) as well as in samples of humans with dietinduced metabolic syndrome (MS) (Furukawa et al., 2004,Urakawa et al., 2003) and are known to promote the progression of liver disease (De Minicis et al., 2006).

Two subunits of the NADPH-oxidase complex (Nox2 and p47phox) were enhanced in mice fed with the HFD, however, the induction was significantly higher in PI3K p110 $\gamma$ deficient than in WT controls (Fig 25). 
(a)

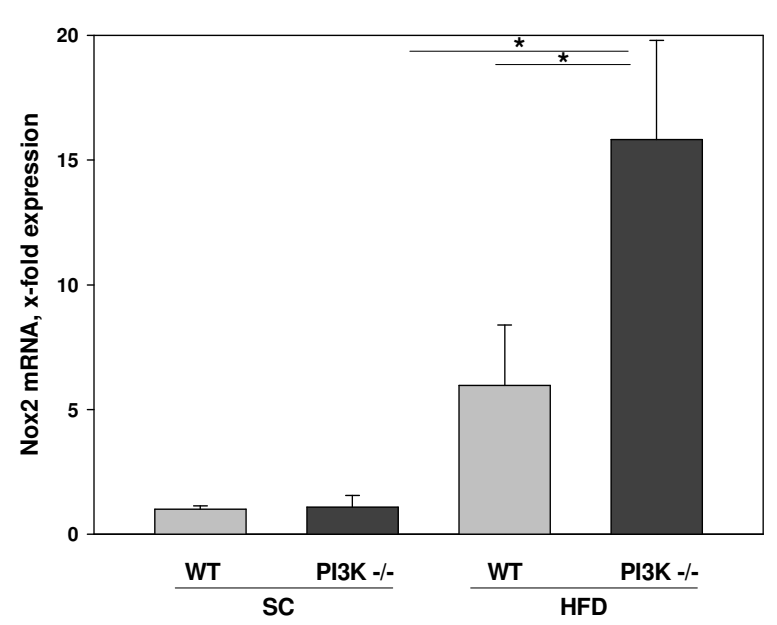

(b)

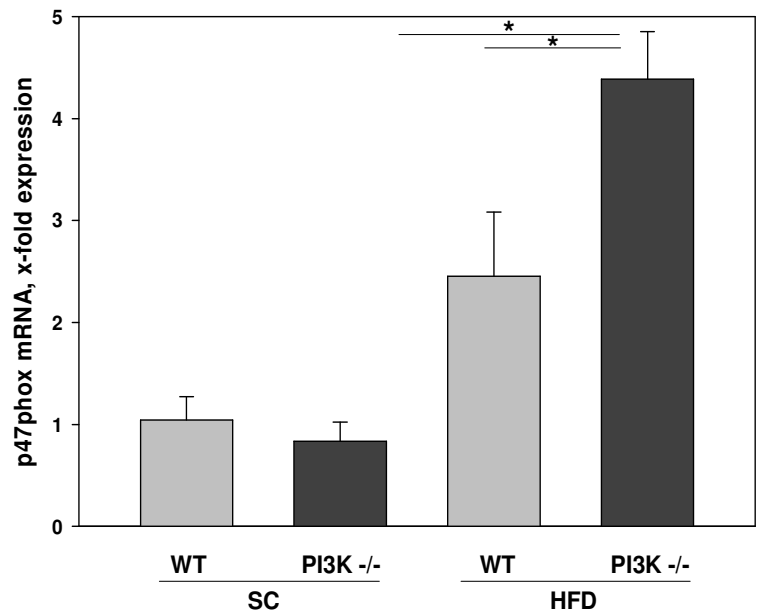

Figure 25: mRNA expression of subunits of NADPH-oxidase complex: (a) Nox2 and (b) p47phox;

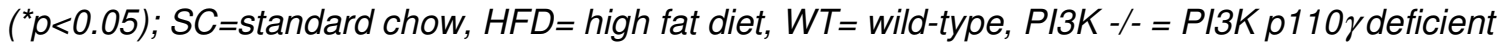

Reactive oxidative species (ROS) are a major feature in the progression of liver disease by exerting oxidative stress on hepatocytes (De Minicis et al., 2006). Several oxidative metabolic procedures like electron transport in mitochondria, activation of the NADPH - oxidase complex or 5-lipooxygenase and activation of members of the Cytochrome P450 superfamily lead to the development of ROS (Novo and Parola, 2008). ROS initiate the generation of lipid peroxides by interacting with polysaturated fatty acids of membrane phospholipids (Esterbauer et al., 1991). These lipid peroxides contribute to the generation of more ROS (vicious circle) and are directly fibrogenic (Galli et al., 2005,Novo and Parola, 2008). Additionally, ROS react with DNA and proteins and consequently cause liver injury by oxidative damage.

4-hydroxy-2-nonenal (HNE) is a major product of endogenous lipid per-oxidation and reacts with several functional groups in the cytoplasm of hepatocytes to form thioester adducts. The presence of these relatively stable adducts is a sign of oxidative stress and is thus considered a good way to evaluate oxidative stress in vivo (Esterbauer et al., 1991,Poli and Parola, 1997). The formed adducts can be visualised by an anti-HNE antiserum. HNE staining was enhanced in the hepatic tissue of mice fed with HFD, however, in PI3K p110 $\gamma$ deficient livers more cells appeared HNE positive and immunosignal was stronger, respectively (Fig 26). 


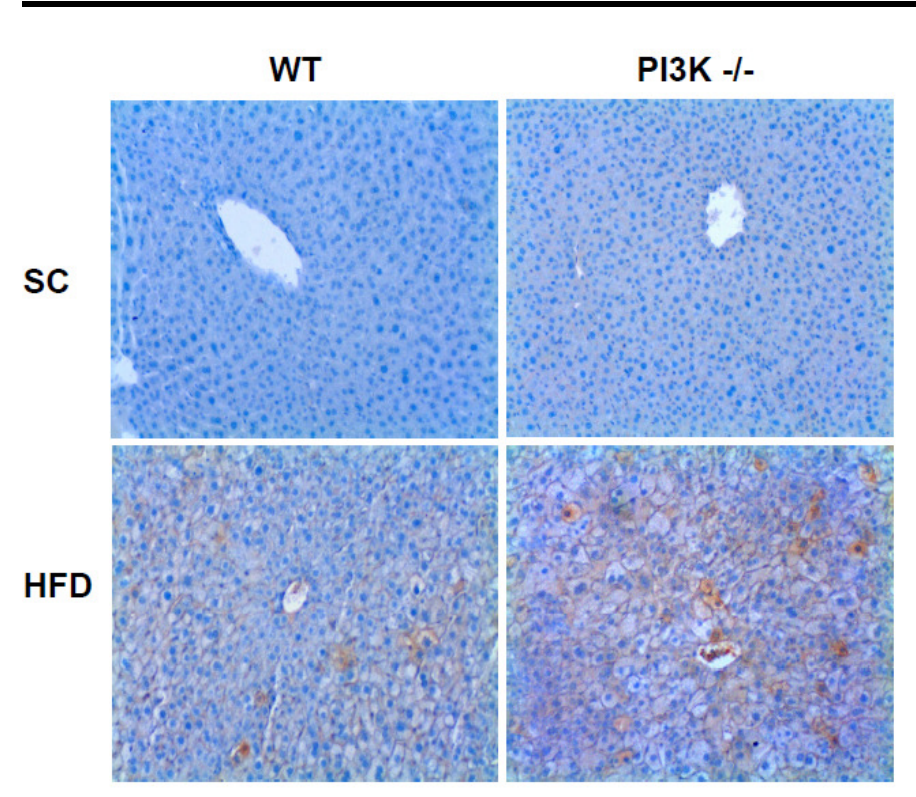

Figure 26: 4-hydroxy-2-nonenal (4-HNE) stain on liver sections; magnification 100x; SC=standard chow, HFD= high fat diet, $W T=$ wild-type, $P I 3 K-/-=P I 3 K$ p110 $\gamma$ deficient

In summary, significantly enhanced hepatic lipid accumulation in PI3K p110 deficient mice appeared a likely cause for the strong fibrogenic response observed in these mice in the NASH model, as it is known that lipid peroxides, which are secreted by hepatocytes under oxidative stress, are strongly fibrogenic by activating HSC in a dose dependant manner (Novo et al., 2006). 


\section{III.5. Analysis of the mechanisms causing the enhanced hepatic lipid accumulation in PI3K p110 $\gamma$ deficient mice in the dietary NASH model}

The concentration of FFA in the liver depends on several factors, which interact in a complex way. Hepatic uptake of FFA depends on the delivery of FFA to the liver as well as the liver's capacity for FFA transport. Further, FFA are generated in the liver by de novo lipogenesis, and FFA are either combusted by oxidation or stored in form of TG or exported via VLDL secretion, respectively (Fabbrini et al., 2010). Assessment of hepatic inflammation and fibrosis described above has been performed in hepatic tissue obtained from mice after 16h fasting. However, it has been shown that fasting of mice may ameliorate or even converse the enhanced expression of key enzymes of hepatic metabolism in dietary NASH models (Morgan et al., 2008). Therefore, we fed a second series of mice with the HFD for 12 weeks but this time harvested the hepatic tissue from mice which had unrestricted access to food until sacrifice. Analysis of hepatic inflammation and fibrosis confirmed the data obtained in the first experimental series (data not shown). Analysis described in the following paragraph has been performed with the mice from series 2 which had not been fasted.

\section{III.5.1. De novo lipogenesis}

NAFLD is initiated by an altered lipid homeostasis (Musso et al., 2009), and one factor that contributes to lipid homeostasis is de novo lipogenesis (Chakravarthy et al., 2005).

Fatty acid synthase (FASN) is believed to determine the maximal capacity of the liver to produce FFA by de novo lipogenesis as it catalyses the last step of this pathway (Menendez et al., 2009). Interestingly, a liver-specific knockout of FASN lead to enhanced steatosis in a nutritional model (Chakravarthy et al., 2005), and our group has shown that FASN levels decreased with the progression of NAFLD in murine models as well as in patients with NAFLD (Dorn et al., 2010b). Accordingly, we observed a downregulation of FASN in mice fed with the NASH 


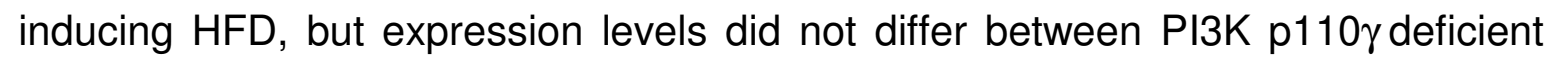
and WT mice (Fig 27), making it unlikely that de novo lipogenesis accounts for the differences observed.

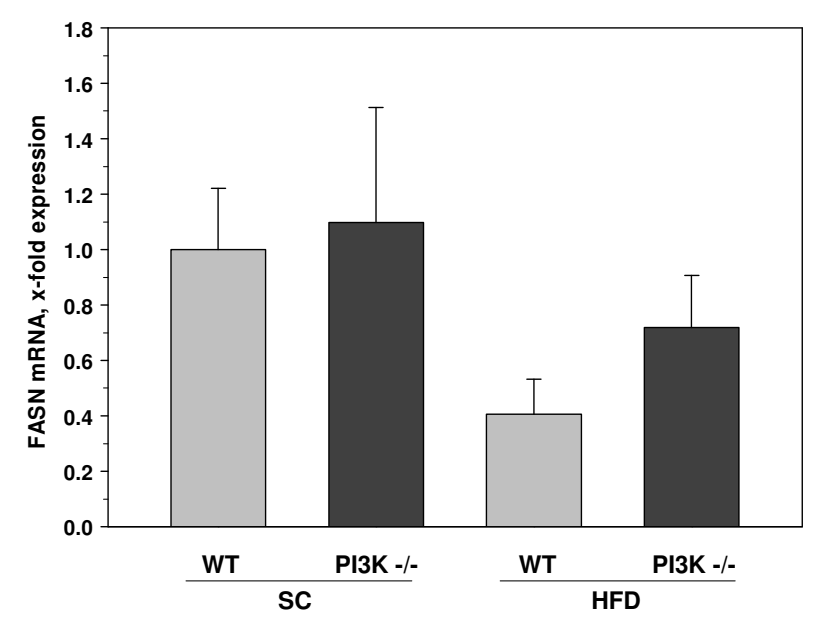

Figure 27: $m R N A$ expression of fatty acid synthase (FASN); $S C=$ standard chow, HFD= high fat diet, $W T=$ wild-type, $P I 3 K-/-=P I 3 K$ p110 deficient

\section{III.5.2. Fatty acid (FA) import and transport}

Another source of hepatic lipid accumulation is uptake of FA from the blood. It was estimated that approximately $75 \%$ of the hepatic triglyceride FA of patients with NAFLD derived from serum nonesterified FA plus dietary FA (Donnelly et al., 2005). Several proteins have been identified that mediate the uptake of FA into the liver including CD36 and FABP. In addition to regulating the transfer of FFA through the cell membrane both proteins are important in the intracellular transport of FFA and esterification into TG (Bonen et al., 2004,Bonen et al., 2007).

The fatty acid translocase (Cluster of Differentiation 36; CD36) is an integral membrane protein that binds fatty acids and channels them through the membrane. It is a key protein in regulating the transfer of free fatty acids (Bonen et al., 2004). CD36 expression is enhanced in rodents with fatty liver and rises relatively to the hepatic TG concentration (Buque et al., 2010, Inoue et al., 2005), whereas reducing steatosis is followed by reduced CD36 expression (Liu et al., 2007). A very recent study showed that CD36 upregulation is also associated with 
increased steatosis in patients with NASH (Miquilena-Colina et al., 2011). qPCR analysis revealed enhanced expression of CD36 in mice fed with HFD, but the increase was significantly higher in PI3K p110 $\gamma$ deficient compared to WT mice (Fig 28).

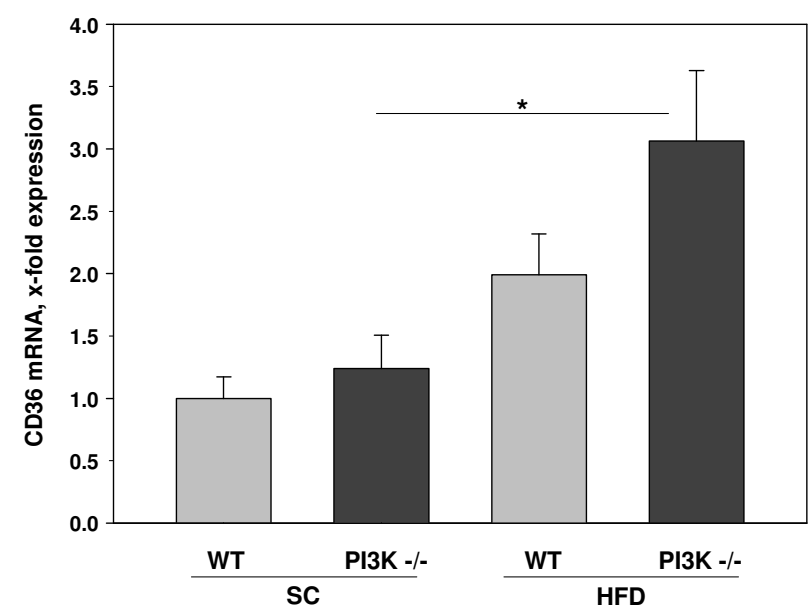

Figure 28: $m R N A$ expression of fatty acid translocase (CD36), $\left({ }^{*} p<0.05\right)$; $S C=$ standard chow, $H F D=$ high fat diet, $W T=$ wild-type, $P I 3 K-/-=P I 3 K$ p110 ${ }^{2}$ deficient

The fatty acid binding protein (FABP) is a carrier protein that facilitates intracellular transports of fatty acids (Chmurzynska, 2006,Weisiger, 2002). FABP binds longchain fatty acids as well as FFA, so that they can be transported to intracellular compartments or the nucleus, where they are either metabolized or activate transcription factors. Normally, liver cells challenged with exogenous fatty acids activate these metabolic pathways to keep FFA and fatty acyl-CoA low (Nguyen et al., 2008). The rate of cytoplasmatic transport of FFA is proportional to the concentration of FABP in the liver (Weisiger, 2002), and inhibition of FABP reduces intracellular FFA transport (Luxon, 1996). Studies with FABP -/- mice showed that these mice exhibited diminished hepatic $\beta$-oxidation that was not caused by an impaired oxidative capacity (Atshaves et al., 2010,Newberry et al., 2003). This result lead to the hypothesis, that hepatic FABP acts as a transporter of FFA to the site of $\beta$-oxidation (Storch and Thumser, 2010). Additionally, FABP deficient mice show reduced FA uptake and decreased hepatic TG levels when fed a HFD (Newberry et al., 2003,Newberry et al., 2006). 
The hepatic isoform is FABP1, and GPCR revealed that the expression of this

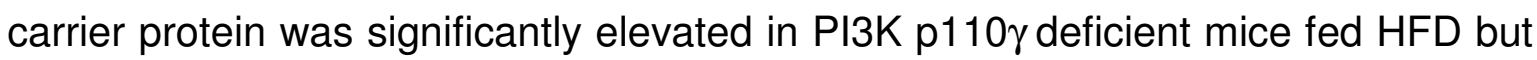
not in WT mice on the same diet (Fig 29).

Taken together these findings indicate that enhanced CD36 and FABP expression may cause an enhanced cellular uptake of FFA as well as an facilitated cytoplasmatic transport of FFA within the cell.

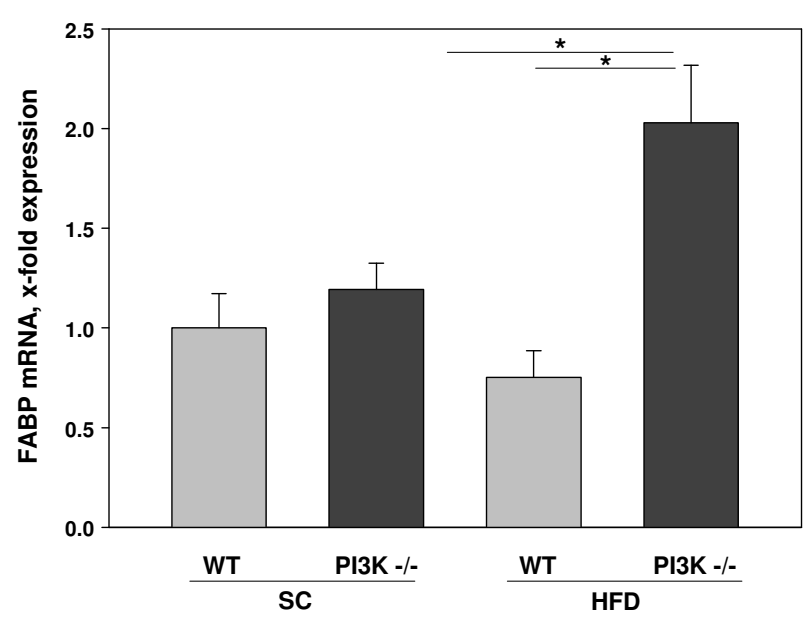

Figure 29: $m R N A$ expression of fatty acid binding protein (FABP), $\left({ }^{*} p<0.05\right)$; $S C=$ standard chow, $H F D=$ high fat diet, $W T=$ wild-type, $P I 3 K-/-=P I 3 K$ p110 $\gamma$ deficient

\section{III.5.3. FFA combustion}

Intra-hepatic FFA are mainly oxidized in mitochondria ( $\beta$-oxidation), but (very) long chain fatty acids are first shortened in peroxisomes ( $\beta$-oxidation) or metabolized by microsomes in the ER ( $\omega$-oxidation) .

The mitochondrial oxidation of FFA is regulated via transport of FFA into the mitochondrial matrix by the carnitine acyltransferase system. As a part of this complex carnitine palmitoyltransferase 1 (CPT-1) is expressed in a liver specific isoform (Kerner and Hoppel, 2000) and can be used as a marker of beta-oxidation. While CPT1 expression did not differ between SC fed and HFD-fed WT mice,

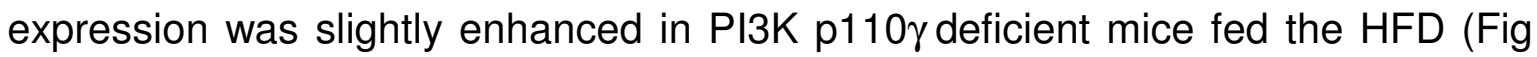
30). 


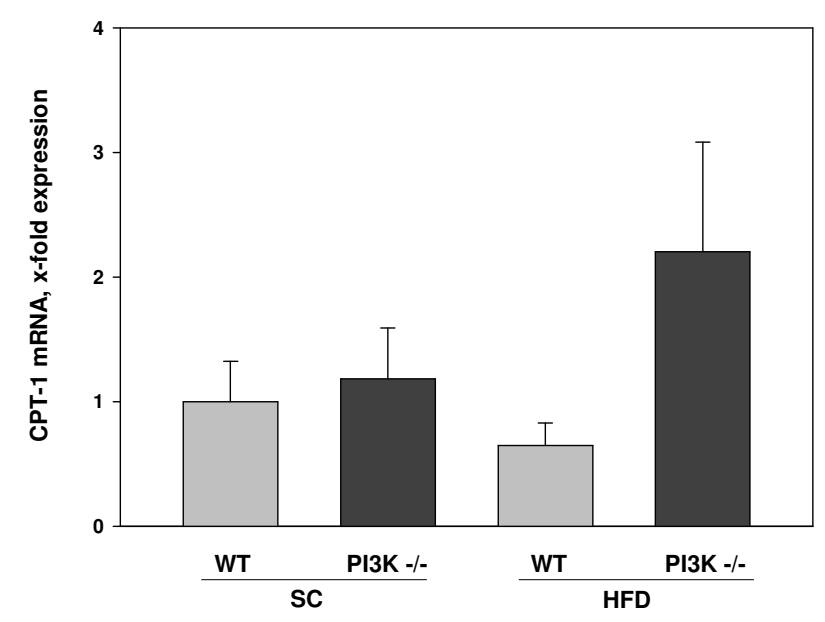

Figure 30: $m R N A$ expression of carnitine palmitoyltransferase $1(C P T-1),\left({ }^{*} p<0.05\right) S C=s t a n d a r d$ chow, HFD= high fat diet, $W T=$ wild-type, $P I 3 K-/-=P I 3 K$ p110 $\gamma$ deficient

Acyl-CoA oxidase 1 (Acox-1) is the first enzyme of the peroxisomal fatty acid oxidation system and cytochrome 4A10 catalyses microsomal fatty acid oxidation. The disruption of Acox-1 leads to the accumulation of long-chain fatty acids and subsequently to an induction of CYP4A10 (Rao and Reddy, 2001), so that these fatty acids can be oxidised in microsomes. Expression of Acox-1 was reduced in mice fed HFD, but expression levels did not differ between WT and PI3K p110 $\gamma$ deficient mice (Fig 31a). CYP4A10 expression levels did not differ between the 4 experimental groups (Fig 31b).

(a)

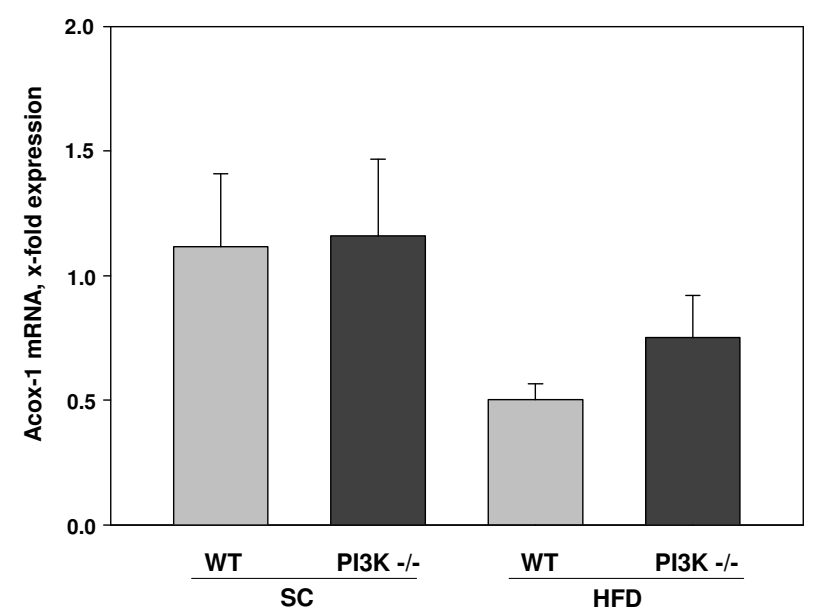

(b)

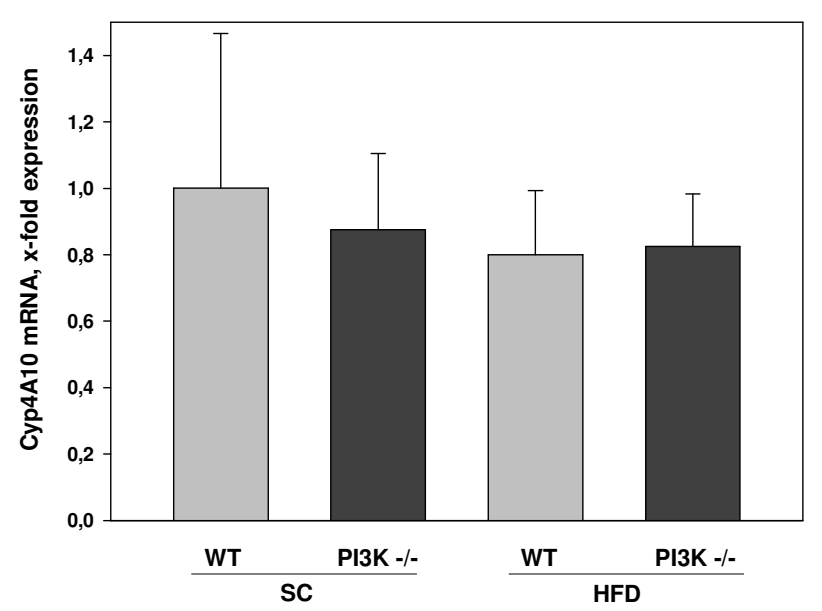

Figure 31: mRNA expression of (a) acyl-coenzyme A oxidase 1 (Acox-1) and (b) cytochrome P450 $4 A 10$ (CYP4A10); SC=standard chow, HFD= high fat diet, $W T=$ wild-type, $P I 3 K-/-=P I 3 K$ p110rdeficient 
These data indicate that the peroxisomal oxidation was probably impaired in HFD fed mice, which may contribute to the accumulation of long-chain fatty acids in the liver. However, equal hepatic expression levels of Acox-1 and CYP4A10 make it unlikely that this mechanism contributes to the differences observed between $\mathrm{PI} 3 \mathrm{~K}$ p110 deficient and WT mice regarding FFA accumulation and hepatocellular injury.

\section{III.5.4. Triglyceride (TG) synthesis}

For the synthesis of triglycerides the acyl-CoA-diglyceride acyltransferase (DGAT) is the crucial enzyme as it catalyzes the formation of triglycerides from diacylglycerol and Acyl-CoA (Cases et al., 1998). There exist two isoforms of DGAT which catalyze similar reactions.

DGAT1 expression was slightly reduced in both chow fed and HFD fed PI3K p110 deficient mice compared to WT controls (Fig 32a). Within the genotypes DGAT1 expression levels did not differ between SC fed and HFD fed groups. DGAT2 was significantly reduced after 12 weeks HFD feeding, but expression levels did not differ significantly between PI3K p110 deficient mice and WT mice (Fig 32b).

(a)

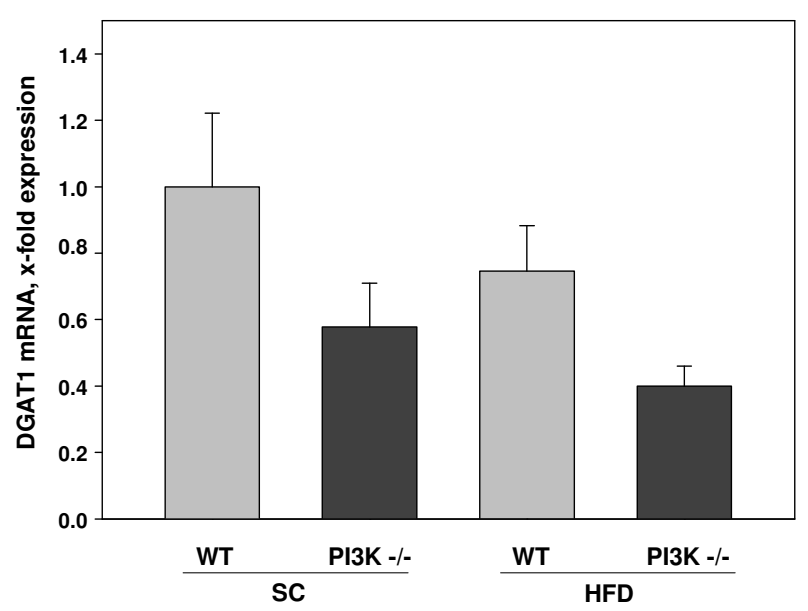

(b)

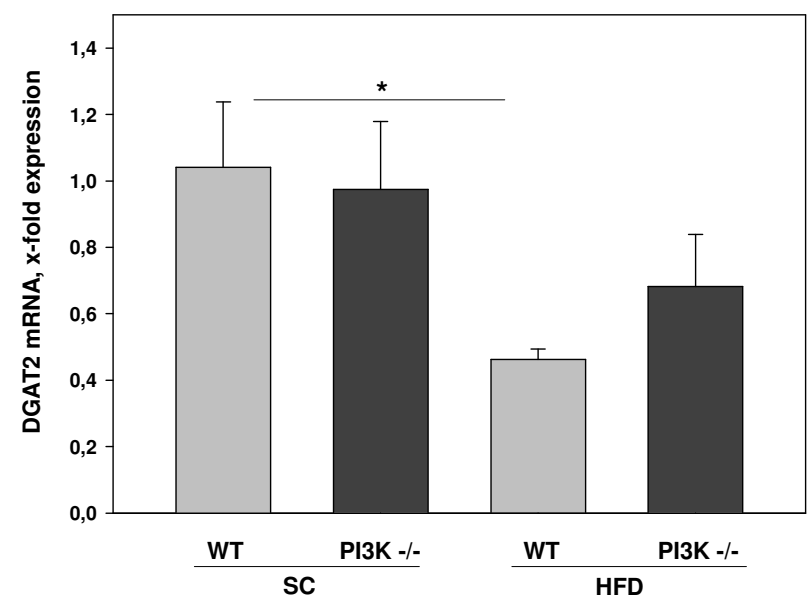

Figure 32: $m R N A$ expression of diglyceride acyltransferase $1+2(D G A T)\left({ }^{*} p<0.05\right) S C=$ standard chow, HFD= high fat diet, $W T=$ wild-type, $P I 3 K-/-=$ PI3K p110 $\gamma$ deficient 
DGAT expression suggested that despite high FFA levels hepatic synthesis of triglycerides was impaired in mice fed the NASH-inducing HFD. At the same time expression of hepatic lipoprotein lipase (LPL) was found to be significantly

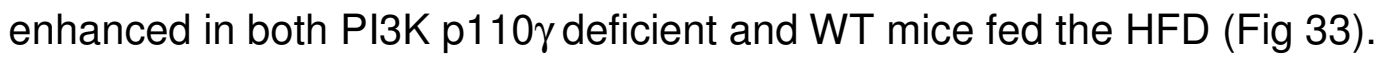

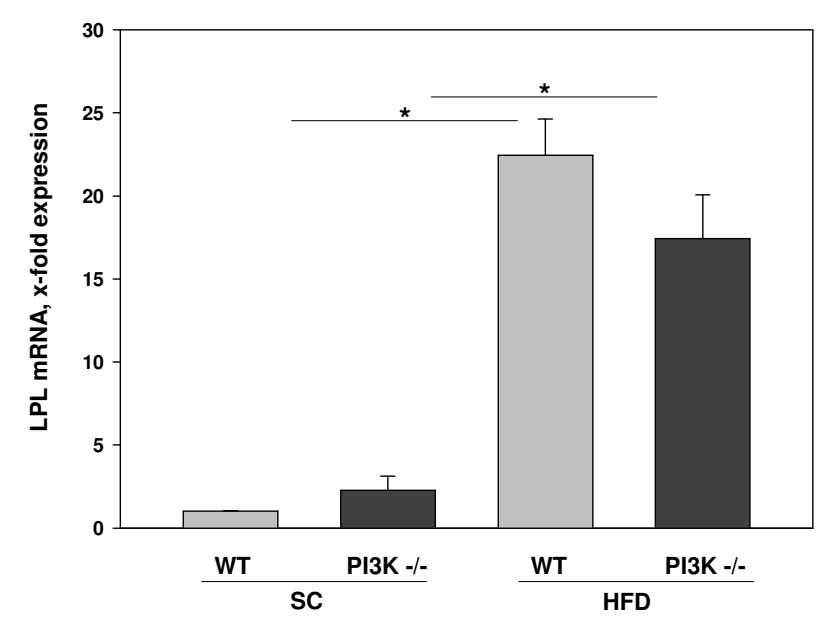

Figure 33: $m R N A$ expression lipoprotein lipase (LPL); $\left.{ }^{*} p<0.05\right)$; $S C=$ standard chow, HFD= high fat diet, $W T=$ wild-type, $P I 3 K-/-=P I 3 K$ p110 $\gamma$ deficient

LPL is an enzyme which mainly catalyzes the hydrolysis of lipids into free fatty acids (lipolysis) and is regulated by insulin (Wang and Eckel, 2009). Pardina et al. examined hepatic LPL-expression in obese patients with NAFLD and suggested that enhanced LPL expression could lead to enhanced hepatocellular FFA accumulation by lipolysis of circulating TG (Pardina et al., 2009).

Together, these data suggest that reduced hepatic synthesis of triglycerides and enhanced hydrolysis of intra-hepatic and circulating triglycerides collectively promote FFA accumulation in the HFD-model. Equal hepatic expression levels of DGAT2 and LPL make it unlikely that this mechanism contributes to the differences observed between genotypes, because only inhibition of DGAT2 but not DGAT1 has been shown to affect hepatocyte TG synthesis and hepatic steatosis (Yamaguchi et al., 2007). 


\section{III.6. Analysis of mechanisms causing the increased hepatic import and combustion of FFA PI3K p110 $\gamma$ deficient mice}

To further assess the mechanisms responsible for enhanced FFA uptake and

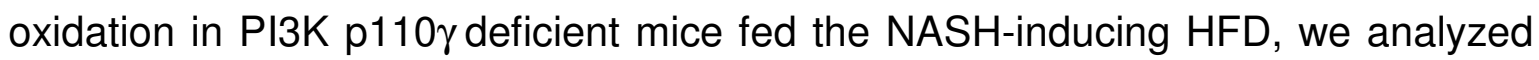
different factors known to influence hepatic lipid metabolism.

\section{III.6.1. Insulin level and signaling}

Insulin levels were increased in the serum of mice fed HFD, but insulin levels did

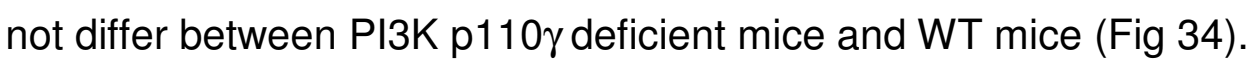

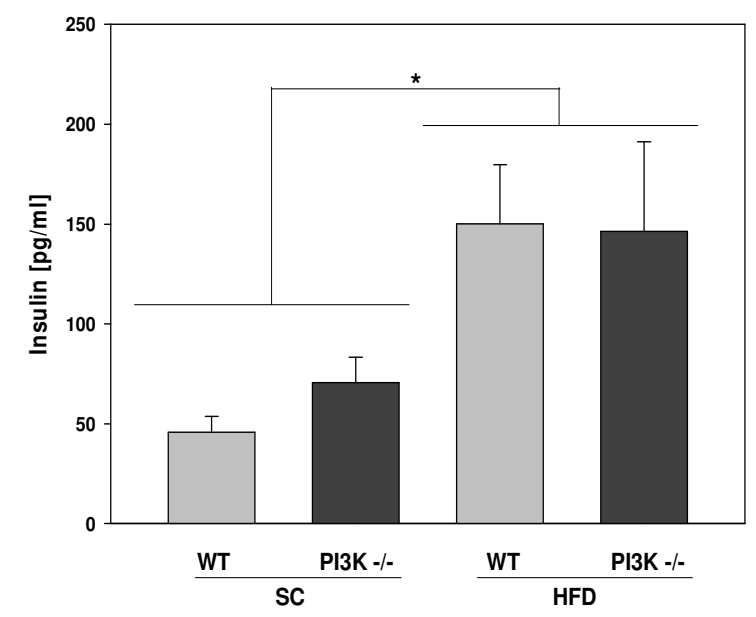

Figure 34: Concentration of insulin in murine serum samples (ELISA); $\left({ }^{*} p<0.05\right) ; S C=$ standard chow, $H F D=$ high fat diet, $W T=$ wild-type, $P I 3 K-/-=P I 3 K$ p110 $\gamma$ deficient

Although PI3K p110 $\gamma$ is not directly involved in the insulin signaling pathway, we next wanted to address whether insulin signaling may be indirectly impaired in PI3K p110 $\gamma$ deficient animals. Firstly, insulin leads to enhanced glycogenesis, and therefore, diminished glucose output from the liver. This effect is mediated via protein kinase $B(P K B / A K T)$ signaling. Secondly, insulin signaling leads to the upregulation of lipid synthesis via protein kinase $C$ (PKC) and increased output of triglycerides (TG) (see Fig 35). However, hepatic insulin resistance usually entails 
only impairment of PKB activation, while signaling via PKC stays intact, so that hepatic insulin resistance is characterized by increased glucose output and TG accumulation (Farese et al., 2005).

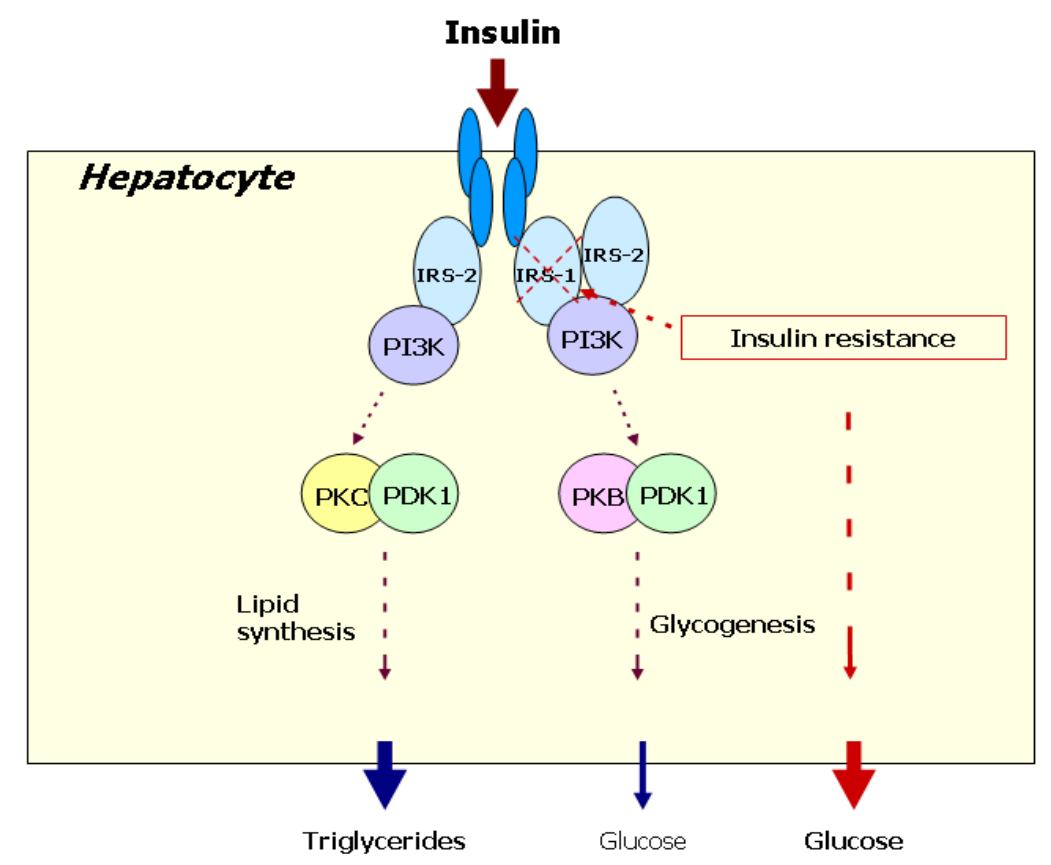

Figure 35: Insulin signaling in the liver: Insulin resistance leads to TG accumulation and enhanced glucose output; based upon a figure by Farese et al. (Farese et al., 2005)

Western blot analysis revealed enhanced PKB-phosphorylation in mice fed the HFD, but no differences between PI3K p110 $\gamma$ deficient and WT mice (Fig 36).

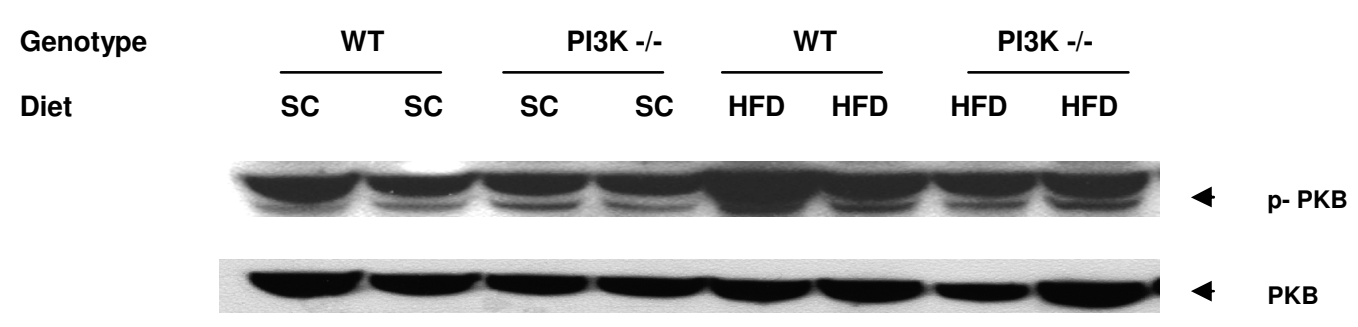

Figure 36: Western blot; upper lane: phospho--protein kinase $B(p-P K B)$, lower lane: protein kinase $B(P K B) ; S C=$ standard chow, HFD= high fat diet, $W T=$ wild-type, $P I 3 K-/-=P I 3 K$ p110 rdeficient 
Fasting serum glucose levels did also not differ between the experimental groups (Fig 37a). To confirm that PI3K p110 $\gamma$ deficient had a normal capacity to metabolize glucose (no insulin resistance) a glucose tolerance test had additionally been performed during the experiment. Mice (all groups) were fasted for 6 hours and then injected i.p. with $3 \mathrm{~g} / \mathrm{kg}$ glucose. At time points $0 \mathrm{~min}, 15 \mathrm{~min}$, $30 \mathrm{~min}$ and $90 \mathrm{~min}$ blood glucose was measured (tail vein). None of the mice showed an impaired glucose tolerance as levels never significantly differed between the groups throughout the experiment, and after $90 \mathrm{~min}$ the serum glucose level was almost back to normal levels in all groups (Fig 37b).

(a)

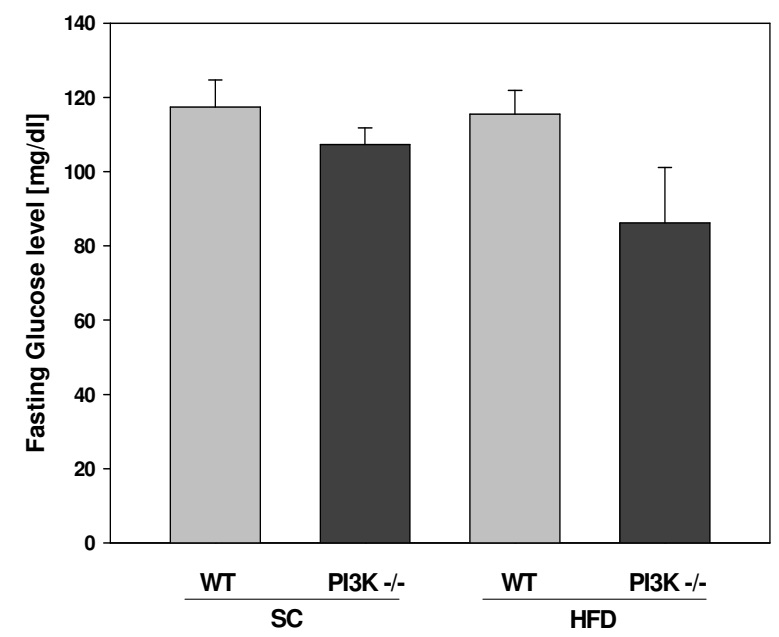

(b)

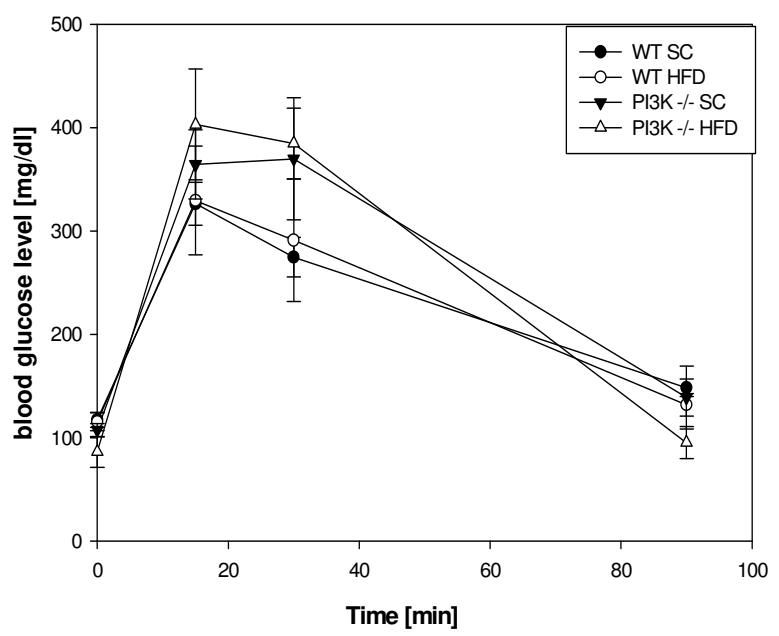

Figure 37: Fasting serum glucose level (a) and glucose tolerance test (b) in mice with NASH vs. control, $S C=$ standard chow, $H F D=$ high fat diet, $W T=$ wild-type, $P I 3 K-/=$ PI3K p110 $\gamma$ deficient

\section{III.6.2. Adiponectin level and signaling}

In addition to insulin, hepatic lipid metabolism is affected by adipocytokines. These molecules that are especially expressed in the visceral fat tissue are known to play a role in obesity-related diseases such as the metabolic syndrome and cardiovascular diseases (Okamoto et al., 2006).

The adipokine adiponectin displays significant metabolic as well as antiinflammatory effects. In hepatocytes adiponectin decreases de novo lipogenesis and increases $\beta$-oxidation so that these cells are protected against triglyceride 
accumulation. There are many studies, which support the fact that adiponectin displays protective properties regarding the development of NASH. Adiponectin improves insulin sensitivity and decreases serum fatty acid levels (Berg et al., 2001,Fruebis et al., 2001,Shklyaev et al., 2003), and patients with NASH display low levels of adiponectin (Hui et al., 2004). It has been shown that adiponectin can alleviate NASH in genetic murine models, i.e. ob/ob mice (Xu et al., 2003). The beneficial effects of adiponectin on the lipid metabolisms are mediated by AMPactivated protein kinase (AMPK) signaling via adiponectin receptor 1 (AdipoR1) (Yamauchi et al., 2007).

Serum adiponectin concentrations were significantly higher in PI3K p110 $\gamma$ deficient mice than in WT control mice in both dietary groups (Fig 38). This seemed to be a discrepancy to the effects of the HFD seen in these mice.

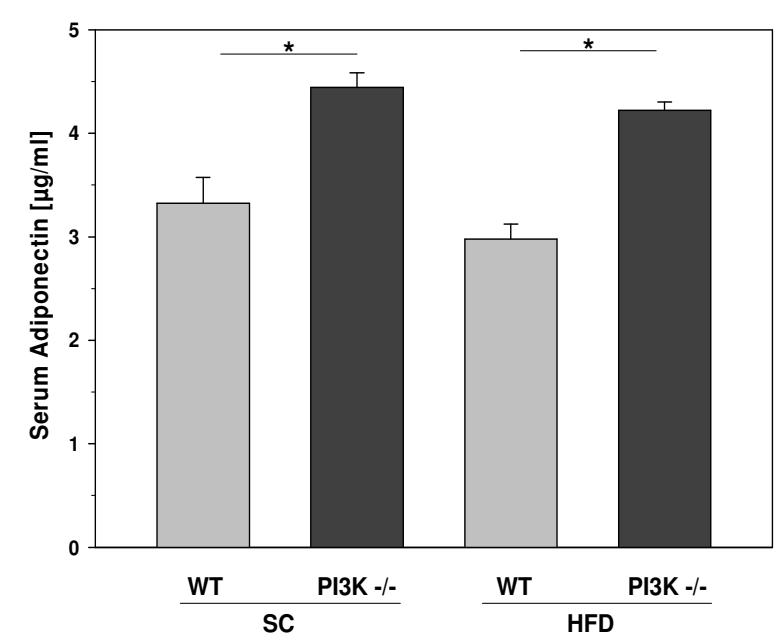

Figure 38: Concentration of Adiponectin in murine serum samples (ELISA), $\quad\left({ }^{*} p<0.05\right)$; $S C=$ standard chow, HFD = high fat diet, $W T=$ wild-type, $P I 3 K-/-=P I 3 K$ p110 $\gamma$ deficient

To get an explanation for this discrepancy the signaling via AdipoR1 and AMPK was examined.

The (AMPK) is a heterotrimer consisting of one catalytic $(\alpha)$ and two regulatory subunits $(\beta, \gamma)$ (Carling, 2004). By being a key enzyme in lipid metabolism AMPK acts as a sensor for the cellular energy status and helps keeping the energy balance by influencing energy production and expenditure (Long and Zierath, 2006). It promotes fatty acid oxidation by blocking ACC (Acetyl-CoA carboxylase) (Winder and Hardie, 1999) and reduces activation of transcription factor sterol regulatory element-binding protein (SREBP) (Purohit et al., 2009). 
As shown by western blot analysis hepatic protein expression of AdipoR1 was reduced in mice with $\mathrm{NASH}$, and consequently, also AMPK was not activated in HFD-fed mice (Fig 39).

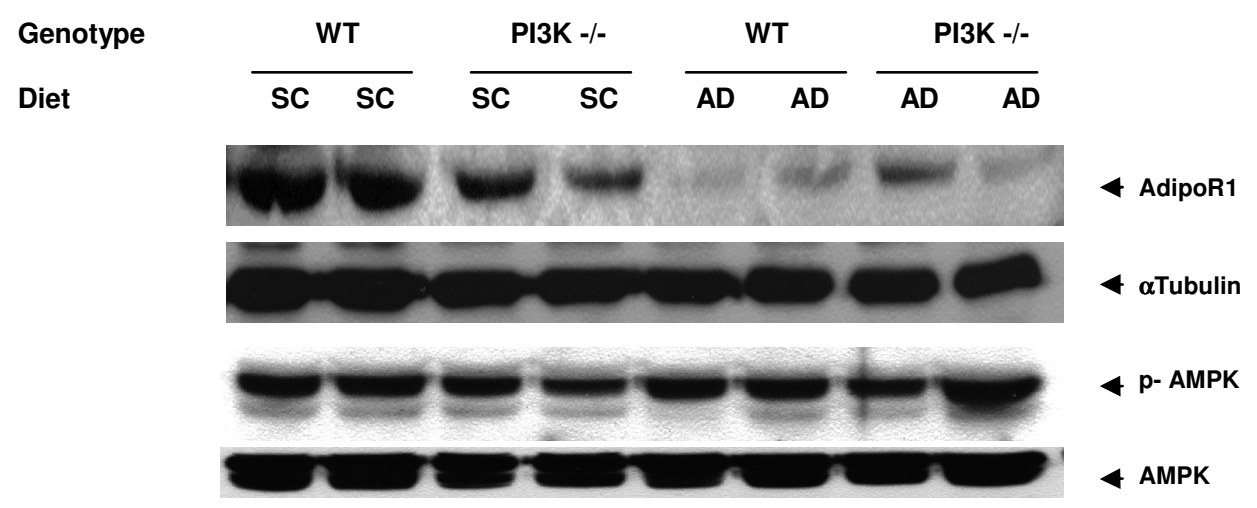

Figure 39: Western blot; upper two lanes: adiponectin receptor $1 \& \alpha$-tubulin, lower lanes: (phospho-) AMP-activated protein kinase ((p)-AMPK; SC=standard chow, HFD= high fat diet, WT=

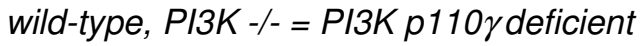

These data indicate that despite elevated serum levels of adiponectin PI3K p110 $\gamma$ deficient mice cannot profit from the beneficial effects of adiponectin of hepatic lipid metabolism in fatty liver disease. However, adiponectin is known to additionally exhibit direct antifibrotic effects independently of its effects on hepatic lipid metabolism (Matsunami et al., 2010,Shafiei et al., 2011,Wanninger et al., 2011). Therefore, one may hypothesize that in the BDL model, where AdipoR1 expression is not affected by hepatic steatosis, PI3K p110 deficient mice profit from elevated adiponectin levels, which may in part explain the differences observed between the two models. 


\section{III.7. PI3K p110 $\gamma$ in hepatic stellate cells (HSC)}

In addition to potential adiponectin effects it was noteworthy that the inhibitory effect of PI3K p110 $\gamma$ deficiency on hepatic fibrosis in the BDL model occurred despite slightly elevated expression of proinflammatory genes (see Fig 9). This prompted us to evaluate the expression of PI3K p110y in HSC, and whether the loss of this PI3K subunit may directly affect HSC, respectively.

\section{III.7.1. PI3K p110 $\gamma$ expression during activation of HSC}

We found that PI3K p110 $\gamma$ was upregulated in an in vitro model of HSC activation (Fig 40a). Primary quiescent HSC were seeded on uncoated cell culture dishes and activated within a few days. The state of activation of HSC was shown by expression of collagen I (Fig 40b).

(a)

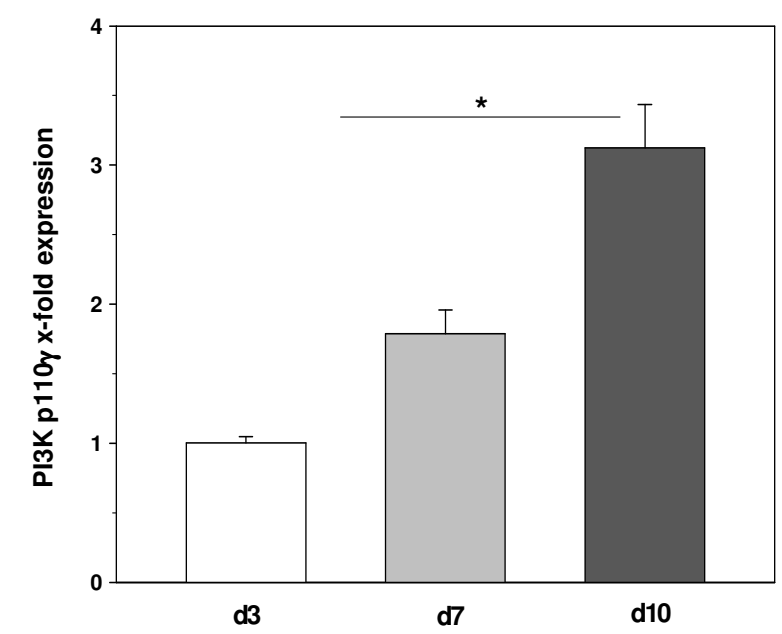

(b)

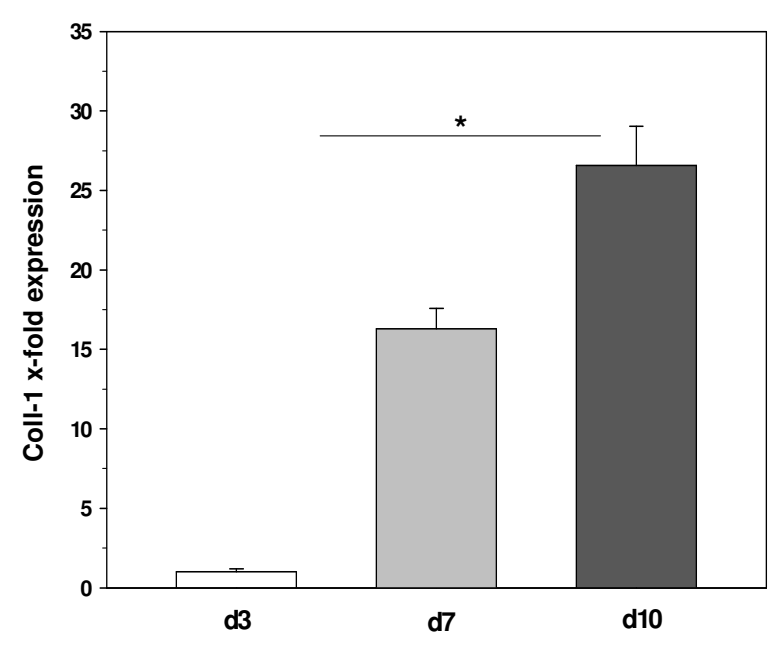

Figure 40: mRNA expression of (a) PI3K p110 $\gamma$ and (b) collagen-1 in activated HSC; day 3-10 of activation (d3-d10); $\left.{ }^{*} p<0.05\right)$

\section{III.7.2. PI3K p110 $\gamma$ expression in FFA stimulated HSC}

Furthermore, we assessed whether incubation with the unsaturated free fatty acid oleic acid affected PI3K p110 expression in HSC. 


\section{III.7.2.1. Dose-response of HSC-B to Oleic acid}

To get an impression how PI3K in general might be involved in the development of $\mathrm{NASH}$ in vitro experiments were done, where HSC were stimulated with an unsaturated free fatty acid (oleic acid). Oleic acid (C18:1 cis- 9) is a monounsaturated omega-9 fatty acid and is the most abundant fatty acid in human adipose tissue (Kokatnur et al., 1979). As NASH is characterized also by more FFA distribution from the adipose tissue to the liver (Donnelly et al., 2005) stimulation with oleic acid was thought to be an adequate way to simulate NASH in vitro.

The following experiments were done with an immortalized activated HSC cell line (HSC $\left.{ }^{\text {hTert }}\right)$.

To determine the adequate concentration of oleic acid a dose-response experiment was done. Stimulation with a gradient of oleic acid for 48 hours showed that a concentration of $50 \mu \mathrm{M}$ and higher lead to an up-regulation of II-8 in the supernatant of stimulated cells (Fig 41a). Measurement of LDH showed that $400 \mu \mathrm{M}$ oleic acid or higher was toxic for the cells (Fig 41b).

(a)

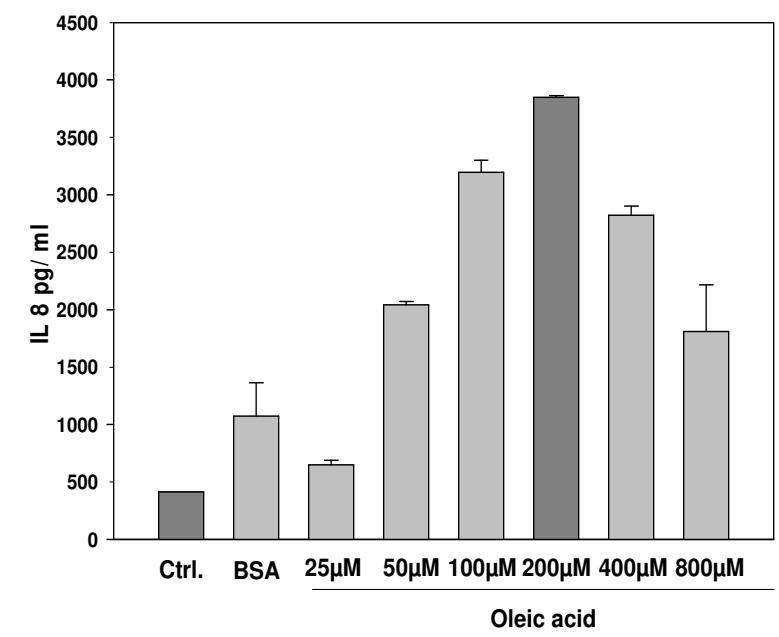

(b)

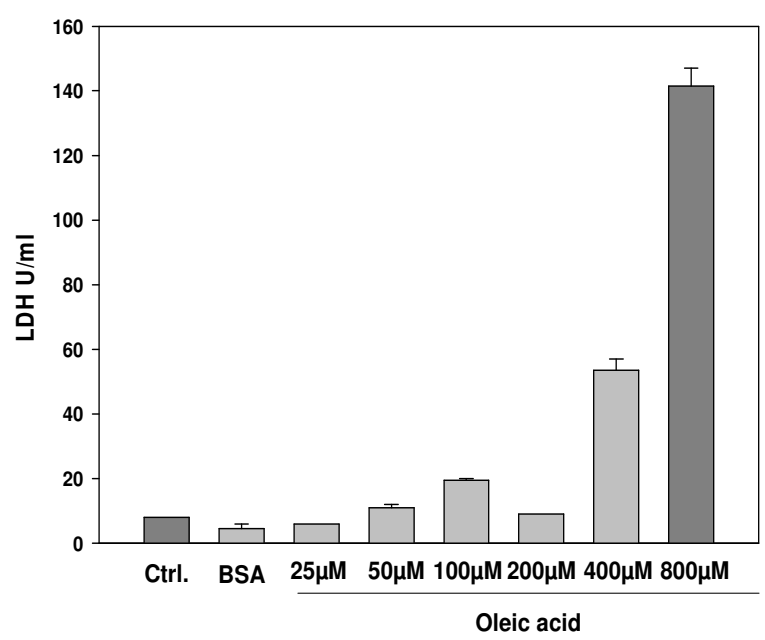

Figure 41: (a) IL-8 ELISA and (b) LDH measurement of supernatant of stimulated HSC ${ }^{\text {hTert }}$ after 48hours incubation with oleic acid in rising concentrations 


\section{III.7.2.2. Time course of IL-8 mRNA expression in response to Oleic acid}

A time course revealed that stimulation with $100 \mu \mathrm{M}$ of oleic acid enhanced mRNA expression of II-8 in a time dependent manner in $\mathrm{HSC}^{\text {hTert }}$, (Fig 42).

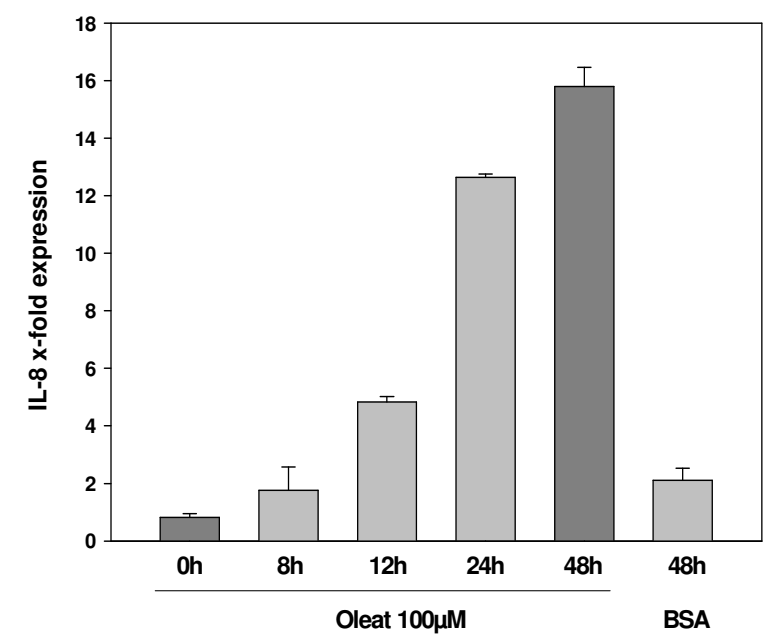

Figure 42: mRNA expression of IL-8 in HSC ${ }^{\text {hTert }}$ after stimulation with $100 \mu \mathrm{M}$ oleic acid at different time points

\section{III.7.2.3. Signaling via p70 S6K after oleic acid stimulation}

Western blot analysis demonstrated that 60-120 min after stimulation with $200 \mu \mathrm{M}$ of oleic acid signaling via $70 \mathrm{kDa}$ ribosomal protein S6 kinase I (p70 S6K) was activated (Fig 43). P70S6K is a serine/ threonine kinase that acts downstream of PIP3 and PDK-1 in the PI3K pathway (Chung et al., 1994).

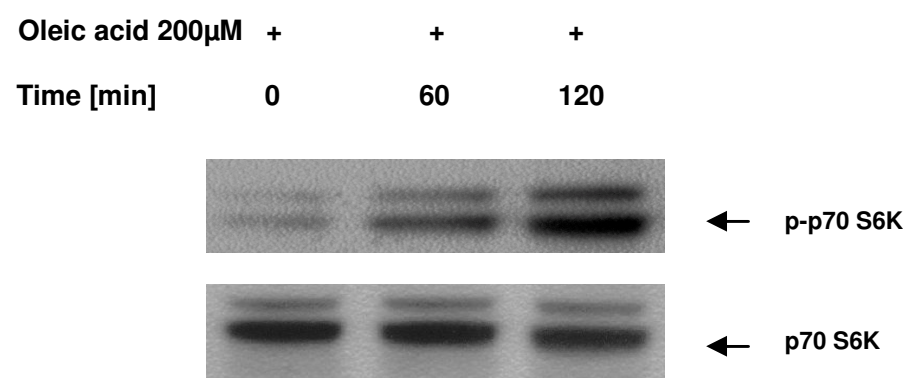

Figure 43: Western blot of cell lysate from stimulated HSC ${ }^{\text {hTert }}$; upper lane: phospho-p70 S6K, lower lane: p70 S6K 


\section{III.7.2.4. II-8 secretion from HSC after blocking of complete PI3K}

Next, signaling via PI3K was blocked using the specific inhibitor LY-294,002 (SIGMA, Deisenhofen, Germany). An ELISA showed that after $24 \mathrm{~h}$ oleic acid caused a significant up-regulation of IL-8 secretion from HSC (Fig 44). This upregulation could partly be blocked by pre-treatment of the cells with LY-294002 (LY), supporting the theory that PI3K is involved in the proinflammatory signaling process of free fatty acids (FFA) in HSC.

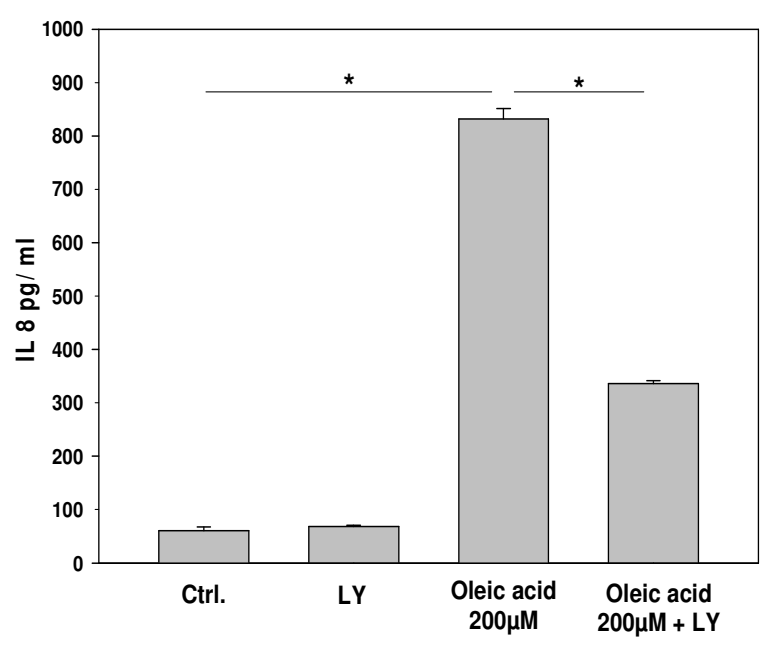

Figure 44: IL-8 ELISA of supernatant of HSC ${ }^{\text {hTert }}$ after stimulation with Oleic acid +/- LY-294,002 $\left({ }^{*} p<0.05\right) ; L Y-294,002=$ specific inhibitor of complete PI3K

Importantly, HSC ${ }^{\text {hTert }}$ did not express $\mathrm{p} 110 \gamma$ in contrast to murine and human activated HSC (data not shown). Treatment with the unselective PI3K inhibitor LY294002 significantly inhibited the oleic acid induced IL-8 mRNA induction in HSC $^{\text {hTert }}$ cells indicating that the oleic mediated effect on IL-8 expression is not mediated via $\gamma$ but via the $\alpha$ or $\beta$ subunit. 


\section{Discussion}

The aim of this project was to assess the expression and function of PI3Kp110 $\gamma$ in chronic liver disease with a focus on hepatic fibrosis.

Until today, PI3Kp110 $\gamma$ has primarily been studied in relation to immune cells. It has been shown that macrophages lacking PI3K p110 $\gamma$ exhibit reduced migration and defective accumulation in vivo (Hirsch et al., 2000). The same study showed that signaling via tyrosine kinases to class $1 \mathrm{~A}$ PI3K was intact in PI3K p110ydeficient cells. Another study demonstrated defective migration of PI3K $\mathrm{p} 110 \gamma$ deficient dendritic cells in vitro and ex vivo (Del Prete et al., 2004). As also the migration of mast cells is inhibited, PI3K p110 $\gamma$ knockout mice are protected against systemic anaphylaxis (Wymann et al., 2003). Furthermore, PI3K p110 $\gamma$ knockout mice are protected from the progression of rheumatoid arthritis (Camps et al., 2005).

With regards to the liver only very few studies assessing the expression and function of PI3K distinguished the effects of individual PI3K subunits. Hohenester et al. have shown that PI3K p110 $\gamma$ contributes to bile acid induced apoptosis of hepatocytes (Hohenester et al., 2010), and a most recent study links the $\alpha$ - and $\beta$ subunit to hepatic lipid and glucose metabolism, respectively (Chattopadhyay et al., 2011). In contrast to these findings until now, the $p 110 \gamma$ unit had not been related to metabolic processes in the liver. Based on its central role in G-coupled receptor signal transduction, one could have expected that PI3K p110 $\gamma$ deficiency would exhibit anti-inflammatory and anti-fibrogenic effect in models of chronic liver injury, as numerous studies have shown the pathological effects of chemokines. In cholestatic liver injury MCP-1 expression is induced in hepatocytes by bile acids and leads to a recruitment of HSCs (Ramm et al., 2009). Several studies connected elevated expression of MCP-1 with hepatic fibrogenesis and HSC proliferation (Czaja et al., 1994,Marra et al., 1998,Muhlbauer et al., 2003). Also MCP-1 receptor deficient mice display reduced liver fibrosis in the BDL model and blocking signaling via the chemokine receptors CCR1 and CCR5 also reduced hepatic fibrosis (Seki et al., 2009b,Seki et al., 2009a). Also Zamara et al. 
demonstrated that MCP-1 deficient mice are protected against the generation of ROS and inflammation in a model for acute toxic liver injury $\left(\mathrm{CCl}_{4}\right)$ (Zamara et al., 2007).

In line with this, PI3K p110 $\gamma$ mice reveal a normal phenotype under standard chow. Further, and in line with the known profibrogenic effect of chemokines PI3K p110 $\gamma$ mice exhibited less fibrosis in the BDL model. Surprisingly, and in contrast to the diminished fibrosis, expression of pro-inflammatory genes TNF and MCP-1 was slightly higher in PI3K p110 $\gamma$ mice. One potential explanation may be a recent study that showed that PI3K $\mathrm{p} 110 \gamma$ is negatively regulated by gradually accumulating ROS in apoptotic neutrophils (Xu et al., 2010). Spontaneous apoptosis of neutrophils plays a crucial role in the resolution of inflammation, so disruption of this feedback loop in PI3K p110ymice may enhance hepatic inflammation in the BDL model. Additionally, a recent study assessing PI3K p110 $\gamma$ deficient mice in a model of chronic colitis suggests that $\mathrm{p} 110 \gamma$ also plays a crucial role in the negative regulation of proinflammatory cytokines (van Dop et al., 2010).

As PI3K p110 $\gamma$ deficiency interrupts G-receptor coupled signaling of chemokines, even in the presence of high levels of MCP-1 or other chemokines recruitment of proinflammatory cells and inflammation is likely diminished in PI3K p110 $\gamma$ deficient mice. Moreover, it is of importance that immune cell function is

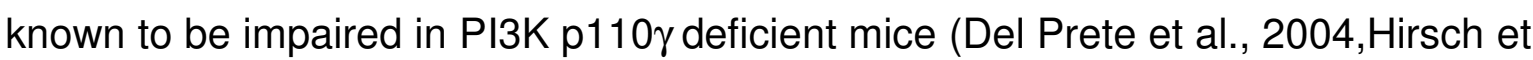
al., 2000,Sasaki et al., 2000,Wymann et al., 2003). Consequently, even if inflammatory cells are present their effect on hepatic inflammation is impaired in PI3K p110 $\gamma$ deficient mice. Thus, even if inflammatory cells are present their effect on hepatic inflammation is impaired in PI3K p110 $\gamma$ deficient mice. Taken together, these findings explain why, although inflammatory gene expression is higher in bile-duct ligated PI3K p110 $\gamma$ mice, this does not translate in enhanced but rather significantly reduced fibrosis compared to WT mice.

In contrast to the BDL model, PI3K p110 $\gamma$ deficient mice revealed significantly more fibrosis in a dietary NASH model. Remarkably, this occurs despite the fact that also in the NASH model PI3K p110 $\gamma$ deficient mice revealed significantly less apoptosis in the liver than WT controls. It has been described that activation of the death receptor Fas promotes hepatocyte apoptosis during the progression of 
NASH (Feldstein et al., 2003) and that the PI3K/Akt pathway has a protective role in Fas-mediated apoptosis (Hatano and Brenner, 2001). Notably, HFD induced FAS upregulation was blunted in PI3K p110 $\gamma$ deficient mice suggesting that this mechanism is at least in part responsible for the reduced apoptosis in PI3K p110 $\gamma$ deficient mice fed HFD compared to wt controls. Still, serum transaminase levels were significantly higher in PI3K p110 $\gamma$ deficient mice than wt mice in the $\mathrm{NASH}$ model indicative of overall more cellular death and necrosis in PI3K p110 $\gamma$ deficient deficient animals. As most likely reason for this phenomenon we found that PI3K p110 $\gamma$ mice revealed significantly higher hepatic lipid accumulation than WT controls in the NASH model.

Our findings suggest that increased hepatocellular FFA uptake and transport lead to enhanced accumulation of FFA in PI3K p110 $\gamma$ deficient livers compared to WT livers. In both PI3K p110 $\gamma$ deficient and WT mice FFA are in part esterified to TGs. Of note, PI3K p110 $\gamma$ deficient mice exhibited enhanced TG levels also on standard chow, suggesting that FFA did not already accumulate under basal conditions because TG synthesis was sufficient to prevent FFA accumulation. Upon HFD feeding TG synthesis was impaired by downregulation of DGAT2, which together with enhanced expression of LPL forced hepatocellular FFA accumulation. Even under HFD FFA accumulation in WT mice was only marginal, but significant in PI3K p110 $\gamma$ livers, and thus, FFA combustion, i.e. $\beta$-oxidation was the only way to get rid of the accumulating FFA. In accordance, CPT-1 expression was enhanced in PI3K p110 $\gamma$ deficient mice and lead to the formation of ROS and lipid peroxides, which are strongly fibrogenic by activating HSC in a dose dependant manner (Novo et al., 2006). Additionally, FFAs promote the process of liver fibrogenesis by inducing hepatocyte apoptosis (Malhi et al., 2007) and act directly profibrogenic on HSC (Canbay et al., 2005, Lu et al., 1998). Also here, we could show in vitro that FFA directly affect IL-8 expression in HSC and IL-8 plays an important pathophysiological role in the progression of liver inflammation and fibrosis (Maher, 2001). Of note, this effect appears to be mediated via the $\alpha$ or $\beta$ unit and not via the PI3K p110 $\gamma$. Thus, one may hypothesise that in the dietary NASH model a direct FFA induced profibrogenic effect took places, which is independent of PI3K p110 r signaling and not present in the BDL model or other models not related to NAFLD. These mechanisms may further contribute to the differences

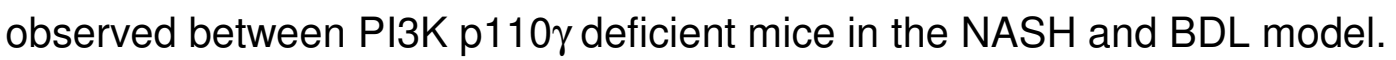


Furthermore and surspringly, we found that adiponectin serum levels were approximately $25 \%$ higher in the PI3K p110 $\gamma$ deficient mice, which is an increase that is biologically relevant. It has been shown that adiponectin concentrations increase by about $36 \%$ in type 2 diabetic patients by $13 \%$ weight loss, and that this may contribute to the metabolic improvements observed in these patients (Pasarica et al., 2009). However, in the PI3K p110 $\gamma$ deficient mice with NASH the protective effect of adiponectin seemed to be partly impaired. The main reason for this impairment probably was the diminished AdipoR1 expression in NASH mice. Impressively, in an experimental NASH model adiponectin receptor $1 / 2$ double knockout mice reveal increased hepatic fat accumulation and inflammation together with elevated oxidative stress (Yamauchi et al., 2007), i.e. similar symptoms as observed in PI3K p110 $\gamma$ deficient mice. In contrast, one may hypothesize that in the BDL model, where AdipoR1 expression is not affected by hepatic steatosis PI3K p110 $\gamma$ deficient mice profit from elevated adiponectin levels, which are known to act anti-fibrogenic. Thus, it has been shown that adiponectin inhibits the activation of hepatic stellate cells (Czaja, 2004) while mice lacking adiponectin (APN -/-) show enhanced carbon tetrachloride-induced liver fibrosis (Kamada et al., 2003). Taken together, elevated adiponectin levels may be one further mechanism explaining the differences observed in PI3K p110 $\gamma$ deficient mice in the two models.

In summary, we found that the PI3K class IB isoform $\mathrm{p} 110 \gamma$ is increased in different murine models of liver fibrosis as well as in the liver of patients with chronic liver disease. However and interestingly, we provide experimental evidence that the effect of PI3K p110 $\gamma$ varies significantly depending on the cause of liver injury. Particularly, in a model of NAFLD PI3K p110 $\gamma$ seems to inhibit hepatic steatosis, inflammation and fibrogenesis. These findings have important clinical implications, because PI3K inhibitors are under clinical development for the treatment of inflammatory disorders and cardiovascular dysfunctions (Ghigo et al., 2010). Particularly the latter and NAFLD share the metabolic syndrome as most common risk factor and frequently coincide. Based on the data of the present study one has to be very cautious regarding harmful effects of a PI3K p110 inhibition in patients with the metabolic syndrome or known NAFLD, respectively. 


\section{References}

Adachi M, Brenner D A. Clinical syndromes of alcoholic liver disease. Dig Dis 2005; (23): 255-263.

Alessi D R, Downes C P. The role of PI 3-kinase in insulin action. Biochim Biophys Acta 1998; (1436): 151-164.

Anstee Q M, Goldin R D. Mouse models in non-alcoholic fatty liver disease and steatohepatitis research. Int J Exp Pathol 2006; (87): 1-16.

Atshaves B P, Martin G G, Hostetler H A, Mclntosh A L, Kier A B, Schroeder F. Liver fatty acid-binding protein and obesity. J Nutr Biochem 2010; (21): 10151032.

Babior B M. NADPH oxidase: an update. Blood 1999; (93): 1464-1476.

Barve A, Khan R, Marsano L, Ravindra K V, McClain C. Treatment of alcoholic liver disease. Ann Hepatol 2008; (7): 5-15.

Bataller R, Brenner D A. Liver fibrosis. J Clin Invest 2005; (115): 209-218.

Bataller R, Gabele E, Parsons C J, Morris T, Yang L, Schoonhoven R, Brenner D A, Rippe R A. Systemic infusion of angiotensin II exacerbates liver fibrosis in bile duct-ligated rats. Hepatology 2005; (41): 1046-1055.

Bellentani S, Tiribelli C, Saccoccio G, Sodde M, Fratti N, De Martin C, Cristianini G. Prevalence of chronic liver disease in the general population of northern Italy: the Dionysos Study. Hepatology 1994; (20): 1442-1449.

Benyon R C, Arthur M J. Extracellular matrix degradation and the role of hepatic stellate cells. Semin Liver Dis 2001; (21): 373-384.

Berg A H, Combs T P, Du X, Brownlee M, Scherer P E. The adipocyte-secreted protein Acrp30 enhances hepatic insulin action. Nat Med 2001; (7): 947-953.

Bergheim I, Guo L, Davis M A, Duveau I, Arteel G E. Critical role of plasminogen activator inhibitor-1 in cholestatic liver injury and fibrosis. J Pharmacol Exp Ther 2006; (316): 592-600.

BLIGH E G, Dyer W.J. A rapid method of total lipid extraction and purification. Can J Biochem Physiol 1959; (37): 911-917.

Bonen A, Campbell S E, Benton C R, Chabowski A, Coort S L, Han X X, Koonen D P, Glatz J F, Luiken J J. Regulation of fatty acid transport by fatty acid translocase/CD36. Proc Nutr Soc 2004; (63): 245-249.

Bonen A, Chabowski A, Luiken J J, Glatz J F. Is membrane transport of FFA mediated by lipid, protein, or both? Mechanisms and regulation of proteinmediated cellular fatty acid uptake: molecular, biochemical, and physiological evidence. Physiology (Bethesda ) 2007; (22): 15-29. 
Browning J D, Szczepaniak L S, Dobbins R, Nuremberg P, Horton J D, Cohen J C, Grundy S M, Hobbs H H. Prevalence of hepatic steatosis in an urban population in the United States: impact of ethnicity. Hepatology 2004; (40): 1387-1395.

Buque X, Martinez M J, Cano A, Miquilena-Colina M E, Garcia-Monzon C, Aspichueta P, Ochoa B. A subset of dysregulated metabolic and survival genes is associated with severity of hepatic steatosis in obese Zucker rats. J Lipid Res 2010; (51): 500-513.

Burgering B M, Medema R $\mathrm{H}$. Decisions on life and death: FOXO Forkhead transcription factors are in command when $\mathrm{PKB} /$ Akt is off duty. $\mathrm{J}$ Leukoc Biol 2003; (73): 689-701.

Camps M, Ruckle T, Ji H, Ardissone V, Rintelen F, Shaw J, Ferrandi C, Chabert C, Gillieron C, Francon B, Martin T, Gretener D, Perrin D, Leroy D, Vitte P A, Hirsch E, Wymann M P, Cirillo R, Schwarz M K, Rommel C. Blockade of PI3Kgamma suppresses joint inflammation and damage in mouse models of rheumatoid arthritis. Nat Med 2005; (11): 936-943.

Canbay A, Gieseler R K, Gores G J, Gerken G. The relationship between apoptosis and non-alcoholic fatty liver disease: an evolutionary cornerstone turned pathogenic. Z Gastroenterol 2005; (43): 211-217.

Carling D. The AMP-activated protein kinase cascade--a unifying system for energy control. Trends Biochem Sci 2004; (29): 18-24.

Cases S, Smith S J, Zheng Y W, Myers H M, Lear S R, Sande E, Novak S, Collins C, Welch C B, Lusis A J, Erickson S K, Farese R V, Jr. Identification of a gene encoding an acyl CoA:diacylglycerol acyltransferase, a key enzyme in triacylglycerol synthesis. Proc Natl Acad Sci U S A 1998; (95): 13018-13023.

Chakravarthy M V, Pan Z, Zhu Y, Tordjman K, Schneider J G, Coleman T, Turk J, Semenkovich C F. "New" hepatic fat activates PPARalpha to maintain glucose, lipid, and cholesterol homeostasis. Cell Metab 2005; (1): 309-322.

Chalhoub N, Baker S J. PTEN and the PI3-kinase pathway in cancer. Annu Rev Pathol 2009; (4): 127-150.

Chattopadhyay M, Selinger E S, Ballou L M, Lin R Z. Ablation of PI3K p110-alpha prevents high-fat diet-induced liver steatosis. Diabetes 2011; (60): 1483-1492.

Chmurzynska A. The multigene family of fatty acid-binding proteins (FABPs): function, structure and polymorphism. J Appl Genet 2006; (47): 39-48.

Chung J, Grammer T C, Lemon K P, Kazlauskas A, Blenis J. PDGF- and insulindependent pp70S6k activation mediated by phosphatidylinositol-3-OH kinase. Nature 1994; (370): 71-75.

Clark J M, Brancati F L, Diehl A M. Nonalcoholic fatty liver disease. Gastroenterology 2002; (122): 1649-1657.

Clouston A D, Powell E E. Interaction of non-alcoholic fatty liver disease with other liver diseases. Best Pract Res Clin Gastroenterol 2002; (16): 767-781.

Contos M J, Sanyal A J. The clinicopathologic spectrum and management of nonalcoholic fatty liver disease. Adv Anat Pathol 2002; (9): 37-51. 
Cousin S P, Hugl S R, Wrede C E, Kajio H, Myers M G, Jr., Rhodes C J. Free fatty acid-induced inhibition of glucose and insulin-like growth factor l-induced deoxyribonucleic acid synthesis in the pancreatic beta-cell line INS-1. Endocrinology 2001; (142): 229-240.

Czaja M J. Liver injury in the setting of steatosis: crosstalk between adipokine and cytokine. Hepatology 2004; (40): 19-22.

Czaja M J, Geerts A, Xu J, Schmiedeberg P, Ju Y. Monocyte chemoattractant protein 1 (MCP-1) expression occurs in toxic rat liver injury and human liver disease. J Leukoc Biol 1994; (55): 120-126.

Day C P. Non-alcoholic steatohepatitis (NASH): where are we now and where are we going? Gut 2002; (50): 585-588.

Day C P, James O F. Steatohepatitis: a tale of two "hits"? Gastroenterology 1998; (114): 842-845.

De Minicis S, Bataller R, Brenner D A. NADPH oxidase in the liver: defensive, offensive, or fibrogenic? Gastroenterology 2006; (131): 272-275.

De Minicis S, Brenner D A. NOX in liver fibrosis. Arch Biochem Biophys 2007; (462): 266-272.

Del Prete A, Vermi W, Dander E, Otero K, Barberis L, Luini W, Bernasconi S, Sironi M, Santoro A, Garlanda C, Facchetti F, Wymann M P, Vecchi A, Hirsch E, Mantovani A, Sozzani S. Defective dendritic cell migration and activation of adaptive immunity in PI3Kgamma-deficient mice. EMBO J 2004; (23): 35053515.

Desmouliere A, Darby I, Costa A M, Raccurt M, Tuchweber B, Sommer P, Gabbiani G. Extracellular matrix deposition, lysyl oxidase expression, and myofibroblastic differentiation during the initial stages of cholestatic fibrosis in the rat. Lab Invest 1997; (76): 765-778.

Diniz Y S, Rocha K K, Souza G A, Galhardi C M, Ebaid G M, Rodrigues H G, Novelli Filho J L, Cicogna A C, Novelli E L. Effects of N-acetylcysteine on sucrose-rich diet-induced hyperglycaemia, dyslipidemia and oxidative stress in rats. Eur J Pharmacol 2006; (543): 151-157.

Donnelly K L, Smith C I, Schwarzenberg S J, Jessurun J, Boldt M D, Parks E J. Sources of fatty acids stored in liver and secreted via lipoproteins in patients with nonalcoholic fatty liver disease. J Clin Invest 2005; (115): 1343-1351.

Dorn C, Kraus B, Motyl M, Weiss T S, Gehrig M, Scholmerich J, Heilmann J, Hellerbrand C. Xanthohumol, a chalcon derived from hops, inhibits hepatic inflammation and fibrosis. Mol Nutr Food Res 2010a; (54 Suppl 2): S205-S213.

Dorn C, Riener M O, Kirovski G, Saugspier M, Steib K, Weiss T S, Gabele E, Kristiansen G, Hartmann A, Hellerbrand C. Expression of fatty acid synthase in nonalcoholic fatty liver disease. Int J Clin Exp Pathol 2010b; (3): 505-514.

Elgouhari H M, Abu-Rajab Tamimi T I, Carey W D. Hepatitis B virus infection: understanding its epidemiology, course, and diagnosis. Cleve Clin J Med 2008; (75): 881-889. 
Esterbauer H, Schaur R J, Zollner H. Chemistry and biochemistry of 4hydroxynonenal, malonaldehyde and related aldehydes. Free Radic Biol Med 1991; (11): 81-128.

Ezure T, Sakamoto T, Tsuji H, Lunz J G, III, Murase N, Fung J J, Demetris A J. The development and compensation of biliary cirrhosis in interleukin-6-deficient mice. Am J Pathol 2000; (156): 1627-1639.

Fabbrini E, Sullivan S, Klein S. Obesity and nonalcoholic fatty liver disease: biochemical, metabolic, and clinical implications. Hepatology 2010; (51): 679689.

Farese R V, Sajan M P, Standaert M L. Insulin-sensitive protein kinases (atypical protein kinase $\mathrm{C}$ and protein kinase B/Akt): actions and defects in obesity and type II diabetes. Exp Biol Med (Maywood) 2005; (230): 593-605.

Feldstein A E, Canbay A, Angulo P, Taniai M, Burgart L J, Lindor K D, Gores G J. Hepatocyte apoptosis and fas expression are prominent features of human nonalcoholic steatohepatitis. Gastroenterology 2003; (125): 437-443.

Foukas L C, Claret M, Pearce W, Okkenhaug K, Meek S, Peskett E, Sancho S, Smith A J, Withers D J, Vanhaesebroeck B. Critical role for the p110alpha phosphoinositide-3-OH kinase in growth and metabolic regulation. Nature 2006; (441): 366-370.

Friedman S L. Molecular regulation of hepatic fibrosis, an integrated cellular response to tissue injury. J Biol Chem 2000; (275): 2247-2250.

Friedman S L. Hepatic stellate cells: protean, multifunctional, and enigmatic cells of the liver. Physiol Rev 2008a; (88): 125-172.

Friedman S L. Mechanisms of hepatic fibrogenesis. Gastroenterology 2008b; (134): 1655-1669.

Fruebis J, Tsao T S, Javorschi S, Ebbets-Reed D, Erickson M R, Yen F T, Bihain $\mathrm{B}$ E, Lodish H F. Proteolytic cleavage product of 30-kDa adipocyte complementrelated protein increases fatty acid oxidation in muscle and causes weight loss in mice. Proc Natl Acad Sci U S A 2001; (98): 2005-2010.

Furukawa S, Fujita T, Shimabukuro M, Iwaki M, Yamada Y, Nakajima Y, Nakayama O, Makishima M, Matsuda M, Shimomura I. Increased oxidative stress in obesity and its impact on metabolic syndrome. J Clin Invest 2004; (114): 1752-1761.

Gabele E, Dostert K, Dorn C, Patsenker E, Stickel F, Hellerbrand C. A new model of interactive effects of alcohol and high-fat diet on hepatic fibrosis. Alcohol Clin Exp Res 2011a; (35): 1361-1367.

Gabele E, Dostert K, Hofmann C, Wiest R, Scholmerich J, Hellerbrand C, Obermeier F. DSS Induced Colitis Increases Portal LPS Levels and Enhances Hepatic Inflammation and Fibrogenesis in Experimental NASH. J Hepatol $2011 b$.

Gabele E, Froh M, Arteel G E, Uesugi T, Hellerbrand C, Scholmerich J, Brenner D A, Thurman R G, Rippe R A. TNFalpha is required for cholestasis-induced liver fibrosis in the mouse. Biochem Biophys Res Commun 2009; (378): 348-353. 
Gabele E, Reif S, Tsukada S, Bataller R, Yata Y, Morris T, Schrum L W, Brenner $D$ A, Rippe $R$ A. The role of p70S6K in hepatic stellate cell collagen gene expression and cell proliferation. J Biol Chem 2005; (280): 13374-13382.

Galli A, Price D, Crabb D. High-level expression of rat class I alcohol dehydrogenase is sufficient for ethanol-induced fat accumulation in transduced HeLa cells. Hepatology 1999; (29): 1164-1170.

Galli A, Svegliati-Baroni G, Ceni E, Milani S, Ridolfi F, Salzano R, Tarocchi M, Grappone C, Pellegrini G, Benedetti A, Surrenti C, Casini A. Oxidative stress stimulates proliferation and invasiveness of hepatic stellate cells via a MMP2mediated mechanism. Hepatology 2005; (41): 1074-1084.

Gates A, Hohenester S, Anwer M S, Webster C R. cAMP-GEF cytoprotection by Src tyrosine kinase activation of phosphoinositide-3-kinase p110 beta/alpha in rat hepatocytes. Am J Physiol Gastrointest Liver Physiol 2009; (296): G764G774.

Geerts A. History, heterogeneity, developmental biology, and functions of quiescent hepatic stellate cells. Semin Liver Dis 2001; (21): 311-335.

Geerts A, Lazou J M, De Bleser P, Wisse E. Tissue distribution, quantitation and proliferation kinetics of fat-storing cells in carbon tetrachloride-injured rat liver. Hepatology 1991; (13): 1193-1202.

Gentilini A, Marra F, Gentilini P, Pinzani M. Phosphatidylinositol-3 kinase and extracellular signal-regulated kinase mediate the chemotactic and mitogenic effects of insulin-like growth factor-I in human hepatic stellate cells. J Hepatol 2000; (32): 227-234.

Ghiassi-Nejad Z, Friedman S L. Advances in antifibrotic therapy. Expert Rev Gastroenterol Hepatol 2008; (2): 803-816.

Ghigo A, Damilano F, Braccini L, Hirsch E. PI3K inhibition in inflammation: Toward tailored therapies for specific diseases. Bioessays 2010; (32): 185-196.

Gressner A M. Cytokines and cellular crosstalk involved in the activation of fatstoring cells. J Hepatol 1995; (22): 28-36.

Gunzl P, Schabbauer G. Recent advances in the genetic analysis of PTEN and PI3K innate immune properties. Immunobiology 2008; (213): 759-765.

Hatano E, Brenner D A. Akt protects mouse hepatocytes from TNF-alpha- and Fas-mediated apoptosis through NK-kappa B activation. Am J Physiol Gastrointest Liver Physiol 2001; (281): G1357-G1368.

Hay N, Sonenberg N. Upstream and downstream of mTOR. Genes Dev 2004; (18): 1926-1945.

Hayashi $\mathrm{H}$, Sakai T. Animal models for the study of liver fibrosis: New insights from knockout mouse models. Am J Physiol Gastrointest Liver Physiol 2011.

Hellerbrand, Wang S C, Tsukamoto H, Brenner D A, Rippe R A. Expression of intracellular adhesion molecule 1 by activated hepatic stellate cells. Hepatology 1996; (24): 670-676. 
Hellerbrand C, Amann T, Schlegel J, Wild P, Bataille F, Spruss T, Hartmann A, Bosserhoff A K. The novel gene MIA2 acts as a tumour suppressor in hepatocellular carcinoma. Gut 2008; (57): 243-251.

Hernandez-Gea V, Friedman S L. Pathogenesis of liver fibrosis. Annu Rev Pathol 2011; (6): 425-456.

Hirsch E, Katanaev V L, Garlanda C, Azzolino O, Pirola L, Silengo L, Sozzani S, Mantovani A, Altruda F, Wymann M P. Central role for G protein-coupled phosphoinositide 3-kinase gamma in inflammation. Science 2000; (287): 10491053.

Hohenester S, Gates A, Wimmer R, Beuers U, Anwer M S, Rust C, Webster C R. Phosphatidylinositol-3-kinase p110gamma contributes to bile salt-induced apoptosis in primary rat hepatocytes and human hepatoma cells. J Hepatol 2010; (53): 918-926.

Hui J M, Hodge A, Farrell G C, Kench J G, Kriketos A, George J. Beyond insulin resistance in NASH: TNF-alpha or adiponectin? Hepatology 2004; (40): 46-54.

Inagaki Y, Okazaki I. Emerging insights into Transforming growth factor beta Smad signal in hepatic fibrogenesis. Gut 2007; (56): 284-292.

Inoue M, Ohtake T, Motomura W, Takahashi N, Hosoki Y, Miyoshi S, Suzuki Y, Saito $\mathrm{H}$, Kohgo $\mathrm{Y}$, Okumura $\mathrm{T}$. Increased expression of PPARgamma in high fat diet-induced liver steatosis in mice. Biochem Biophys Res Commun 2005; (336): 215-222.

Isayama F, Hines I N, Kremer M, Milton R J, Byrd C L, Perry A W, McKim S E, Parsons C, Rippe R A, Wheeler M D. LPS signaling enhances hepatic fibrogenesis caused by experimental cholestasis in mice. Am J Physiol Gastrointest Liver Physiol 2006; (290): G1318-G1328.

Jeong W I, Jeong D H, DO S H, Kim Y K, Park H Y, Kwon O D, Kim T H, Jeong K $\mathrm{S}$. Mild hepatic fibrosis in cholesterol and sodium cholate diet-fed rats. J Vet Med Sci 2005; (67): 235-242.

Kamada Y, Tamura S, Kiso S, Matsumoto H, Saji Y, Yoshida Y, Fukui K, Maeda $\mathrm{N}$, Nishizawa H, Nagaretani H, Okamoto Y, Kihara S, Miyagawa J, Shinomura Y, Funahashi T, Matsuzawa Y. Enhanced carbon tetrachloride-induced liver fibrosis in mice lacking adiponectin. Gastroenterology 2003; (125): 1796-1807.

Katso R, Okkenhaug K, Ahmadi K, White S, Timms J, Waterfield M D. Cellular function of phosphoinositide 3-kinases: implications for development, homeostasis, and cancer. Annu Rev Cell Dev Biol 2001; (17): 615-675.

Kerner J, Hoppel C. Fatty acid import into mitochondria. Biochim Biophys Acta 2000; (1486): 1-17.

Kersten S, Seydoux J, Peters J M, Gonzalez F J, Desvergne B, Wahli W. Peroxisome proliferator-activated receptor alpha mediates the adaptive response to fasting. J Clin Invest 1999; (103): 1489-1498.

Kirovski G, Gabele E, Dorn C, Moleda L, Niessen C, Weiss T S, Wobser H, Schacherer D, Buechler C, Wasmuth H E, Hellerbrand C. Hepatic steatosis causes induction of the chemokine RANTES in the absence of significant hepatic inflammation. Int J Clin Exp Pathol 2010; (3): 675-680. 
Kirsch R, Clarkson V, Shephard E G, Marais D A, Jaffer M A, Woodburne V E, Kirsch R E, Hall P L. Rodent nutritional model of non-alcoholic steatohepatitis: species, strain and sex difference studies. J Gastroenterol Hepatol 2003; (18): 1272-1282.

Kokatnur M G, Oalmann M C, Johnson W D, Malcom G T, Strong J P. Fatty acid composition of human adipose tissue from two anatomical sites in a biracial community. Am J Clin Nutr 1979; (32): 2198-2205.

Koppe S W, Sahai A, Malladi P, Whitington P F, Green R M. Pentoxifylline attenuates steatohepatitis induced by the methionine choline deficient diet. $J$ Hepatol 2004; (41): 592-598.

Leclercq I A, Farrell G C, Schriemer R, Robertson G R. Leptin is essential for the hepatic fibrogenic response to chronic liver injury. J Hepatol 2002; (37): 206213.

Liang J, Slingerland J M. Multiple roles of the PI3K/PKB (Akt) pathway in cell cycle progression. Cell Cycle 2003; (2): 339-345.

Lieber C S, Schmidt R. The effect of ethanol on fatty acid metabolism; stimulation of hepatic fatty acid synthesis in vitro. J Clin Invest 1961; (40): 394-399.

Lindquist J N, Parsons C J, Stefanovic B, Brenner D A. Regulation of alpha1(I) collagen messenger RNA decay by interactions with alphaCP at the $3^{\prime}-$ untranslated region. J Biol Chem 2004; (279): 23822-23829.

Liu L F, Purushotham A, Wendel A A, Belury M A. Combined effects of rosiglitazone and conjugated linoleic acid on adiposity, insulin sensitivity, and hepatic steatosis in high-fat-fed mice. Am J Physiol Gastrointest Liver Physiol 2007; (292): G1671-G1682.

Long Y C, Zierath J R. AMP-activated protein kinase signaling in metabolic regulation. J Clin Invest 2006; (116): 1776-1783.

Lu L G, Zeng M D, Li J Q, Hua J, Fan J G, Qiu D K. Study on the role of free fatty acids in proliferation of rat hepatic stellate cells (II). World J Gastroenterol 1998; (4): 500-502.

Ludwig J, Viggiano T R, McGill D B, Oh B J. Nonalcoholic steatohepatitis: Mayo Clinic experiences with a hitherto unnamed disease. Mayo Clin Proc 1980; (55): 434-438.

Luxon B A. Inhibition of binding to fatty acid binding protein reduces the intracellular transport of fatty acids. Am J Physiol 1996; (271): G113-G120.

Maher $\mathrm{J} \mathrm{J}$. Interactions between hepatic stellate cells and the immune system. Semin Liver Dis 2001; (21): 417-426.

Malhi H, Barreyro F J, Isomoto H, Bronk S F, Gores G J. Free fatty acids sensitise hepatocytes to TRAIL mediated cytotoxicity. Gut 2007; (56): 1124-1131.

Marra F, DeFranco R, Grappone C, Milani S, Pastacaldi S, Pinzani M, Romanelli R G, Laffi G, Gentilini P. Increased expression of monocyte chemotactic protein-1 during active hepatic fibrogenesis: correlation with monocyte infiltration. Am J Pathol 1998; (152): 423-430. 
Marra F, Valente A J, Pinzani M, Abboud H E. Cultured human liver fat-storing cells produce monocyte chemotactic protein-1. Regulation by proinflammatory cytokines. J Clin Invest 1993; (92): 1674-1680.

Matsunami T, Sato Y, Ariga S, Sato T, Kashimura H, Hasegawa Y, Yukawa M. Regulation of oxidative stress and inflammation by hepatic adiponectin receptor 2 in an animal model of nonalcoholic steatohepatitis. Int J Clin Exp Pathol 2010; (3): 472-481.

Matsuzawa N, Takamura T, Kurita S, Misu H, Ota T, Ando H, Yokoyama M, Honda M, Zen Y, Nakanuma Y, Miyamoto K, Kaneko S. Lipid-induced oxidative stress causes steatohepatitis in mice fed an atherogenic diet. Hepatology 2007; (46): 1392-1403.

Matsuzawa-Nagata N, Takamura T, Ando H, Nakamura S, Kurita S, Misu H, Ota T, Yokoyama M, Honda M, Miyamoto K, Kaneko S. Increased oxidative stress precedes the onset of high-fat diet-induced insulin resistance and obesity. Metabolism 2008; (57): 1071-1077.

Menendez J A, Vazquez-Martin A, Ortega F J, Fernandez-Real J M. Fatty acid synthase: association with insulin resistance, type 2 diabetes, and cancer. Clin Chem 2009; (55): 425-438.

Miquilena-Colina M E, Lima-Cabello E, Sanchez-Campos S, Garcia-Mediavilla M V, Fernandez-Bermejo M, Lozano-Rodriguez T, Vargas-Castrillon J, Buque X, Ochoa B, Aspichueta P, Gonzalez-Gallego J, Garcia-Monzon C. Hepatic fatty acid translocase CD36 upregulation is associated with insulin resistance, hyperinsulinaemia and increased steatosis in non-alcoholic steatohepatitis and chronic hepatitis C. Gut 2011.

Misra S, Varticovski L, Arias I M. Mechanisms by which cAMP increases bile acid secretion in rat liver and canalicular membrane vesicles. Am J Physiol Gastrointest Liver Physiol 2003; (285): G316-G324.

Morgan K, Uyuni A, Nandgiri G, Mao L, Castaneda L, Kathirvel E, French S W, Morgan T R. Altered expression of transcription factors and genes regulating lipogenesis in liver and adipose tissue of mice with high fat diet-induced obesity and nonalcoholic fatty liver disease. Eur J Gastroenterol Hepatol 2008; (20): 843-854.

Muhlbauer M, Bosserhoff A K, Hartmann A, Thasler W E, Weiss T S, Herfarth $H$, Lock G, Scholmerich J, Hellerbrand C. A novel MCP-1 gene polymorphism is associated with hepatic MCP-1 expression and severity of HCV-related liver disease. Gastroenterology 2003; (125): 1085-1093.

Musso G, Gambino R, Cassader M. Recent insights into hepatic lipid metabolism in non-alcoholic fatty liver disease (NAFLD). Prog Lipid Res 2009; (48): 1-26.

Newberry E P, Xie Y, Kennedy S, Han X, Buhman K K, Luo J, Gross R W, Davidson $\mathrm{N} \mathrm{O}$. Decreased hepatic triglyceride accumulation and altered fatty acid uptake in mice with deletion of the liver fatty acid-binding protein gene. $\mathrm{J}$ Biol Chem 2003; (278): 51664-51672.

Newberry E P, Xie Y, Kennedy S M, Luo J, Davidson N O. Protection against Western diet-induced obesity and hepatic steatosis in liver fatty acid-binding protein knockout mice. Hepatology 2006; (44): 1191-1205. 
Nguyen P, Leray V, Diez M, Serisier S, Le Bloc'h J, Siliart B, Dumon H. Liver lipid metabolism. J Anim Physiol Anim Nutr (Berl) 2008; (92): 272-283.

Novo E, Marra F, Zamara E, Valfre d B, Caligiuri A, Cannito S, Antonaci C, Colombatto S, Pinzani M, Parola M. Dose dependent and divergent effects of superoxide anion on cell death, proliferation, and migration of activated human hepatic stellate cells. Gut 2006; (55): 90-97.

Novo E, Parola M. Redox mechanisms in hepatic chronic wound healing and fibrogenesis. Fibrogenesis Tissue Repair 2008; (1): 5.

Okamoto Y, Kihara S, Funahashi T, Matsuzawa Y, Libby P. Adiponectin: a key adipocytokine in metabolic syndrome. Clin Sci (Lond) 2006; (110): 267-278.

Paigen B, Morrow A, Brandon C, Mitchell D, Holmes P. Variation in susceptibility to atherosclerosis among inbred strains of mice. Atherosclerosis 1985; (57): 6573.

Paik Y H, Schwabe R F, Bataller R, Russo M P, Jobin C, Brenner D A. Toll-like receptor 4 mediates inflammatory signaling by bacterial lipopolysaccharide in human hepatic stellate cells. Hepatology 2003; (37): 1043-1055.

Pardina E, Baena-Fustegueras J A, Llamas R, Catalan R, Galard R, Lecube A, Fort J M, Llobera M, Allende H, Vargas V, Peinado-Onsurbe J. Lipoprotein lipase expression in livers of morbidly obese patients could be responsible for liver steatosis. Obes Surg 2009; (19): 608-616.

Pasarica M, Tchoukalova Y D, Heilbronn L K, Fang X, Albu J B, Kelley D E, Smith $S R$, Ravussin E. Differential effect of weight loss on adipocyte size subfractions in patients with type 2 diabetes. Obesity (Silver Spring) 2009; (17): 1976-1978.

Poli G. Pathogenesis of liver fibrosis: role of oxidative stress. Mol Aspects Med 2000; (21): 49-98.

Poli G, Parola M. Oxidative damage and fibrogenesis. Free Radic Biol Med 1997; (22): 287-305.

Powell E E, Cooksley W G, Hanson R, Searle J, Halliday J W, Powell L W. The natural history of nonalcoholic steatohepatitis: a follow-up study of forty-two patients for up to 21 years. Hepatology 1990; (11): 74-80.

Purohit V, Gao B, Song B J. Molecular mechanisms of alcoholic fatty liver. Alcohol Clin Exp Res 2009; (33): 191-205.

Ramadori G, Veit T, Schwogler S, Dienes H P, Knittel T, Rieder H, Meyer zum Buschenfelde $\mathrm{K} \mathrm{H}$. Expression of the gene of the alpha-smooth muscle-actin isoform in rat liver and in rat fat-storing (ITO) cells. Virchows Arch B Cell Pathol Incl Mol Pathol 1990; (59): 349-357.

Ramm G A, Shepherd R W, Hoskins A C, Greco S A, Ney A D, Pereira T N, Bridle $K$ R, Doecke J D, Meikle P J, Turlin B, Lewindon P J. Fibrogenesis in pediatric cholestatic liver disease: role of taurocholate and hepatocyte-derived monocyte chemotaxis protein-1 in hepatic stellate cell recruitment. Hepatology 2009; (49): 533-544.

Rao M S, Reddy J K. Peroxisomal beta-oxidation and steatohepatitis. Semin Liver Dis 2001; (21): 43-55. 
Rector R S, Thyfault J P, Wei Y, Ibdah J A. Non-alcoholic fatty liver disease and the metabolic syndrome: an update. World J Gastroenterol 2008; (14): 185-192.

Reeves H L, Friedman S L. Activation of hepatic stellate cells--a key issue in liver fibrosis. Front Biosci 2002; (7): d808-d826.

Reid A E. Nonalcoholic steatohepatitis. Gastroenterology 2001; (121): 710-723.

Reif S, Lang A, Lindquist J N, Yata Y, Gabele E, Scanga A, Brenner D A, Rippe R $A$. The role of focal adhesion kinase-phosphatidylinositol 3-kinase-akt signaling in hepatic stellate cell proliferation and type I collagen expression. J Biol Chem 2003; (278): 8083-8090.

Romestaing C, Piquet M A, Bedu E, Rouleau V, Dautresme M, Hourmand-Ollivier I, Filippi C, Duchamp C, Sibille B. Long term highly saturated fat diet does not induce NASH in Wistar rats. Nutr Metab (Lond) 2007; (4): 4.

Ruhl C E, Everhart J E. Epidemiology of nonalcoholic fatty liver. Clin Liver Dis 2004; (8): 501-19, vii.

Ryan C M, Carter E A, Jenkins R L, Sterling L M, Yarmush M L, Malt R A, Tompkins R G. Isolation and long-term culture of human hepatocytes. Surgery 1993; (113): 48-54.

Sasaki T, Irie-Sasaki J, Jones R G, Oliveira-dos-Santos A J, Stanford W L, Bolon B, Wakeham A, Itie A, Bouchard D, Kozieradzki I, Joza N, Mak T W, Ohashi P S, Suzuki A, Penninger J M. Function of PI3Kgamma in thymocyte development, T cell activation, and neutrophil migration. Science 2000; (287): 1040-1046.

Schnabl B, Choi Y H, Olsen J C, Hagedorn C H, Brenner D A. Immortal activated human hepatic stellate cells generated by ectopic telomerase expression. Lab Invest 2002; (82): 323-333.

Schonfeld P, Wojtczak L. Fatty acids as modulators of the cellular production of reactive oxygen species. Free Radic Biol Med 2008; (45): 231-241.

Seki E, De Minicis S, Gwak G Y, Kluwe J, Inokuchi S, Bursill C A, Llovet J M, Brenner D A, Schwabe R F. CCR1 and CCR5 promote hepatic fibrosis in mice. J Clin Invest 2009a; (119): 1858-1870.

Seki E, De Minicis S, Inokuchi S, Taura K, Miyai K, van Rooijen N, Schwabe R F, Brenner D A. CCR2 promotes hepatic fibrosis in mice. Hepatology 2009b; (50): 185-197.

Seki E, De Minicis S, Osterreicher C H, Kluwe J, Osawa Y, Brenner D A, Schwabe R F. TLR4 enhances TGF-beta signaling and hepatic fibrosis. Nat Med 2007; (13): 1324-1332.

Shafiei M S, Shetty S, Scherer P E, Rockey D C. Adiponectin Regulation of Stellate Cell Activation via PPARgamma-Dependent and -Independent Mechanisms. Am J Pathol 2011; (178): 2690-2699.

Shimano H, Horton J D, Hammer R E, Shimomura I, Brown M S, Goldstein J L. Overproduction of cholesterol and fatty acids causes massive liver enlargement in transgenic mice expressing truncated SREBP-1a. J Clin Invest 1996; (98): 1575-1584. 
Shiojima I, Walsh K. Regulation of cardiac growth and coronary angiogenesis by the Akt/PKB signaling pathway. Genes Dev 2006; (20): 3347-3365.

Shklyaev S, Aslanidi G, Tennant M, Prima V, Kohlbrenner E, Kroutov V, CampbellThompson M, Crawford J, Shek E W, Scarpace P J, Zolotukhin S. Sustained peripheral expression of transgene adiponectin offsets the development of dietinduced obesity in rats. Proc Natl Acad Sci U S A 2003; (100): 14217-14222.

Son G, Hines I N, Lindquist J, Schrum L W, Rippe R A. Inhibition of phosphatidylinositol 3-kinase signaling in hepatic stellate cells blocks the progression of hepatic fibrosis. Hepatology 2009; (50): 1512-1523.

Stefanovic B, Hellerbrand C, Brenner D A. Regulatory role of the conserved stemloop structure at the $5^{\prime}$ end of collagen alpha1(I) mRNA. Mol Cell Biol 1999; (19): 4334-4342.

Storch J, Thumser A E. Tissue-specific functions in the fatty acid-binding protein family. J Biol Chem 2010; (285): 32679-32683.

Surwit R S, Feinglos M N, Rodin J, Sutherland A, Petro A E, Opara E C, Kuhn C $M$, Rebuffe-Scrive M. Differential effects of fat and sucrose on the development of obesity and diabetes in C57BL/6J and A/J mice. Metabolism 1995; (44): 645651.

Teli M R, Day C P, Burt A D, Bennett M K, James O F. Determinants of progression to cirrhosis or fibrosis in pure alcoholic fatty liver. Lancet 1995; (346): 987-990.

Tuchweber B, Desmouliere A, Bochaton-Piallat M L, Rubbia-Brandt L, Gabbiani G. Proliferation and phenotypic modulation of portal fibroblasts in the early stages of cholestatic fibrosis in the rat. Lab Invest 1996; (74): 265-278.

Uchinami H, Seki E, Brenner D A, D'Armiento J. Loss of MMP 13 attenuates murine hepatic injury and fibrosis during cholestasis. Hepatology 2006; (44): 420-429.

Urakawa H, Katsuki A, Sumida Y, Gabazza E C, Murashima S, Morioka K, Maruyama N, Kitagawa N, Tanaka T, Hori Y, Nakatani K, Yano Y, Adachi Y. Oxidative stress is associated with adiposity and insulin resistance in men. $J$ Clin Endocrinol Metab 2003; (88): 4673-4676.

van Dop W A, Marengo S, te Velde A A, Ciraolo E, Franco I, ten Kate F J, Boeckxstaens G E, Hardwick J C, Hommes D W, Hirsch E, van den Brink G R. The absence of functional PI3Kgamma prevents leukocyte recruitment and ameliorates DSS-induced colitis in mice. Immunol Lett 2010; (131): 33-39.

Wake K. "Sternzellen" in the liver: perisinusoidal cells with special reference to storage of vitamin A. Am J Anat 1971; (132): 429-462.

Wang H, Eckel R H. Lipoprotein lipase: from gene to obesity. Am J Physiol Endocrinol Metab 2009; (297): E271-E288.

Wang $\mathrm{H}$, Zhang $\mathrm{Y}$, Heuckeroth $\mathrm{R} \mathrm{O}$. PAl-1 deficiency reduces liver fibrosis after bile duct ligation in mice through activation of tPA. FEBS Lett 2007; (581): 30983104.

Wanninger J, Neumeier M, Bauer S, Weiss T S, Eisinger K, Walter R, Dorn C, Hellerbrand C, Schaffler A, Buechler C. Adiponectin induces the transforming 
growth factor decoy receptor BAMBI in human hepatocytes. FEBS Lett 2011; (585): 1338-1344.

Wasley A, Alter M J. Epidemiology of hepatitis C: geographic differences and temporal trends. Semin Liver Dis 2000; (20): 1-16.

Watanabe S, Horie Y, Suzuki A. Hepatocyte-specific Pten-deficient mice as a novel model for nonalcoholic steatohepatitis and hepatocellular carcinoma. Hepatol Res 2005; (33): 161-166.

Wedemeyer I, Bechmann L P, Odenthal M, Jochum C, Marquitan G, Drebber U, Gerken G, Gieseler R K, Dienes H P, Canbay A. Adiponectin inhibits steatotic CD95/Fas up-regulation by hepatocytes: therapeutic implications for hepatitis $C$. J Hepatol 2009; (50): 140-149.

Weisiger R A. Cytosolic fatty acid binding proteins catalyze two distinct steps in intracellular transport of their ligands. Mol Cell Biochem 2002; (239): 35-43.

Weiss T S, Jahn B, Cetto M, Jauch K W, Thasler W E. Collagen sandwich culture affects intracellular polyamine levels of human hepatocytes. Cell Prolif 2002; (35): 257-267.

Weltman M D, Farrell G C, Liddle C. Increased hepatocyte CYP2E1 expression in a rat nutritional model of hepatic steatosis with inflammation. Gastroenterology 1996; (111): 1645-1653.

Winder W W, Hardie D G. AMP-activated protein kinase, a metabolic master switch: possible roles in type 2 diabetes. Am J Physiol 1999; (277): E1-10.

Wymann M P, Bjorklof K, Calvez R, Finan P, Thomast M, Trifilieff A, Barbier M, Altruda F, Hirsch E, Laffargue M. Phosphoinositide 3-kinase gamma: a key modulator in inflammation and allergy. Biochem Soc Trans 2003; (31): 275-280.

Xu A, Wang Y, Keshaw H, Xu L Y, Lam K S, Cooper G J. The fat-derived hormone adiponectin alleviates alcoholic and nonalcoholic fatty liver diseases in mice. $\mathrm{J}$ Clin Invest 2003; (112): 91-100.

$\mathrm{Xu}$ Y, Loison F, Luo H R. Neutrophil spontaneous death is mediated by downregulation of autocrine signaling through GPCR, PI3Kgamma, ROS, and actin. Proc Natl Acad Sci U S A 2010; (107): 2950-2955.

Yamaguchi K, Yang L, McCall S, Huang J, Yu X X, Pandey S K, Bhanot S, Monia B P, Li Y X, Diehl A M. Inhibiting triglyceride synthesis improves hepatic steatosis but exacerbates liver damage and fibrosis in obese mice with nonalcoholic steatohepatitis. Hepatology 2007; (45): 1366-1374.

Yamauchi T, Nio Y, Maki T, Kobayashi M, Takazawa T, Iwabu M, Okada-Iwabu M, Kawamoto S, Kubota N, Kubota T, Ito Y, Kamon J, Tsuchida A, Kumagai K, Kozono H, Hada Y, Ogata H, Tokuyama K, Tsunoda M, Ide T, Murakami K, Awazawa M, Takamoto I, Froguel P, Hara K, Tobe K, Nagai R, Ueki K, Kadowaki T. Targeted disruption of AdipoR1 and AdipoR2 causes abrogation of adiponectin binding and metabolic actions. Nat Med 2007; (13): 332-339.

Younossi Z M, Diehl A M, Ong J P. Nonalcoholic fatty liver disease: an agenda for clinical research. Hepatology 2002; (35): 746-752.

Zamara E, Galastri S, Aleffi S, Petrai I, Aragno M, Mastrocola R, Novo E, Bertolani C, Milani S, Vizzutti F, Vercelli A, Pinzani M, Laffi G, LaVilla G, Parola M, Marra 
F. Prevention of severe toxic liver injury and oxidative stress in MCP-1-deficient mice. J Hepatol 2007; (46): 230-238.

Zhang L P, Takahara T, Yata Y, Furui K, Jin B, Kawada N, Watanabe A. Increased expression of plasminogen activator and plasminogen activator inhibitor during liver fibrogenesis of rats: role of stellate cells. J Hepatol 1999; (31): 703-711. 


\section{Appendix}

\section{Vl.1. Abbreviations}

$\alpha \mathrm{SMA}$

${ }^{\circ} \mathrm{C}$

(c)DNA

$\mu \mathrm{g}$

$\mu l$

$\mu \mathrm{M}$

Acox-1

AD

AdipoR1

ALD

ALT

AMPK

$\mathrm{ASH}$

AST

BCA

BDL

bp

BSA

$\mathrm{Ca}$

$\mathrm{CCl}_{4}$

CD36

cDNA

$\mathrm{Cl}$

Coll-I

CYP

CYP7A1

d alpha smooth muscle actin

degree Celsius

(complementary) deoxyribonucleic acid

microgram

microliter

micromolar

acyl-coenzyme A oxidase 1

atherogenic diet (Paigen)

adiponectin receptor 1

alcoholic liver disease

alanine aminotransferase

AMP-activated protein kinase

alcoholic steatohepatitis

aspartate aminotransferase

bicinchonic acid

bile duct ligation

base pairs

bovine serum albumin

Calcium

carbon tetrachloride

fatty acid translocase (Cluster of

Differentiation 36)

complementary DNA

chloride

collagen type I

cytochrome P450

cholesterol-7 $\alpha$-hydroxylase

day 
DEPC

DGAT

dl

DMEM

DMSO

dNTP

e.g.

ECL

ECM

EDTA

ELISA

et al.

$\mathrm{EtOH}$

EU

FABP

Fas

FasL

FASN

FCS

(F)FA

Fig

FoxO1

g

GPCR

GSK3

$\mathrm{h}$

H/E

$\mathrm{H}_{2} \mathrm{SO}_{4}$

$\mathrm{H}_{2} \mathrm{O}_{2}$

$\mathrm{H}_{2}$ Odist.

$\mathrm{HCl}$

$\mathrm{HCV}$

HNE

HRP
Diethylpyrocarbonate

diglyceride acyltransferase

decilitre

Dulbecco's modified eagle medium

dimethyl sulfoxide

deoxyribonucleosidtriphophate

exempli gratia

enhanced chemiluminescence

extracellular matrix

ethylene diamine tetra acetate

enzyme linked immunosorbent assay

et alii

ethanol

ELISA unit

fatty acid binding protein

TNF receptor superfamily, member 6

Fas ligand

fatty acid synthase

fetal calf serum

(free) fatty acid(s)

figure

mammalian forkhead members of the class $\mathrm{O} 1$

gram

G protein-coupled receptor

glycogen synthase kinase 3

hour

haematoxylin/eosin

sulphuric acid

hydrogen peroxide

distilled water

hydrochloric acid

hepatitis $C$ virus

hydroxynonenal

horseradish peroxidase 
HSC

i.p.

IL-8

INF $\gamma$

IU

$\mathrm{kg}$

LAL

$\mathrm{LDH}$

LPL

LPS

$M$

$\mathrm{mA}$

MCD diet

MCP-1

$\mathrm{mg}$

$\mathrm{MgCl}_{2}$

$\min$

$\mathrm{ml}$

$\mathrm{mM}$

mRNA

mTOR

MTTP

$\mathrm{Na}_{3} \mathrm{~N}$

$\mathrm{NADH}$

$\mathrm{NADPH}$

NAFLD

$\mathrm{NaOH}$

$\mathrm{NASH}$

$\mathrm{NF} \kappa \mathrm{B}$

$\mathrm{nm}$

Nox2

p4 $7^{\text {phox }}$

p70S6K

Pai-1 hepatic stellate cell

intraperitoneal

interleukin 8

interferon $\gamma$

insulin unit

kilogram

limulus amebocyte lysate assay

lactate dehydrogenase

lipoprotein lipase

lipopolysaccharide

molar, $\mathrm{mol} / \mathrm{l}$

milliampere

methionine-choline deficient diet

monocyte chemoattractant protein 1

milligram

magnesium chloride

minute(s)

millilitre

millimolar

messenger ribonucleic acid

mammalian target of rapamycin

microsomal triglyceride transfer protein

Sodium nitride

nicotinamide adenine dinucleotide

Nicotinamide adenine dinucleotide

phosphate (reduced)

non-alcoholic fatty liver disease

sodium hydroxide

non-alcoholic steatohepatitis

nuclear factor $\mathrm{kB}$

nanometre

subunit NADPH oxidase complex

subunit NADPH oxidase complex

ribosomal p70 S6 kinase

plasminogen activator inhibitor 


\begin{tabular}{|c|c|}
\hline PBS & phosphate buffered saline \\
\hline PCR & polymerase chain reaction \\
\hline PDGF & platelet derived growth factor \\
\hline \multirow[t]{2}{*}{ PDK-1 } & Pyruvate dehydrogenase kinase isozyme \\
\hline & 1 \\
\hline $\mathrm{pg}$ & pictogram \\
\hline $\mathrm{pH}$ & potentia hydrogenii \\
\hline $\mathrm{PI} 3 \mathrm{~K}$ & phosphatidyl-inositol-3-kinase \\
\hline PIP & phosphoinositol lipid(s) \\
\hline PKB & protein kinase $B(A K T)$ \\
\hline PKC & protein kinase $\mathrm{C}$ \\
\hline PMSF & phenylmethylsulfonyl fluoride \\
\hline \multirow[t]{2}{*}{ PPAR } & proliferator-activated \\
\hline & receptor \\
\hline PTEN & phosphatase and tensin homologue \\
\hline$p$-value & probability value (statistics) \\
\hline ROS & reactive oxygen species \\
\hline rpm & rounds per minute \\
\hline RT & reverse transcriptase \\
\hline RTK & receptor tyrosine kinase \\
\hline $\mathrm{s}$ & second \\
\hline SC & standard chow (control diet) \\
\hline SDS & sodium-dodecyl-sulfate \\
\hline \multirow[t]{2}{*}{ SREBP-1 } & sterol regulatory element-binding protein- \\
\hline & 1 \\
\hline TBE & tris-borate-EDTA \\
\hline TBS & tris-buffered saline \\
\hline TE & tris EDTA \\
\hline TG & triglyceride(s) \\
\hline TGF $\beta$ & transforming growth factor $\beta$ \\
\hline \multirow[t]{2}{*}{ TIMP-1 } & tissue inhibitor \\
\hline & metalloproteinases 1 \\
\hline TLR & toll-like receptor \\
\hline TNF & tumor necrosis factor \\
\hline TWEEN & Polyoxyethylene sorbitan monolaurate \\
\hline
\end{tabular}


U

UV

$\mathrm{V}$

VLDL

vs.

W

WT unit

ultraviolet

Volt

very low density lipoprotein

versus

week

wild-type 


\section{VI.2. Bisherige Präsentation der Daten dieser Arbeit}

Vortrag:

Forschungswochenende der Klinik und Poliklinik der Inneren Medizin I, Universität Regensburg (09. - 10. Okt. 2009, Lengenfeld, Germany)

- Dostert K, Wiest R, Schölmerich J, Hellerbrand C, Gäbele E: Unterschiedliche Rolle der PI3K bei durch NASH und BDL induzierter Leberfibrose

Posterpräsentation:

$45^{\text {th }}$ Annual meeting of the European Association for the study of the Liver (EASL), Wien, 15.-18.04.2010

- Dostert K, Wiest R, Schölmerich J, Hellerbrand C, Gäbele E: Deficiency of phosphatidylinositol 3-kinase (PI3K) aggravates inflammation and fibrosis in experimental $\mathrm{NASH}$ but protects against bile duct ligation induced fibrosis in vivo

27. Jahrestagung der Deutschen Arbeitsgemeinschaft zum Studium der Leber (GASL), Regensburg, 28.-29.01.2011

- Dostert K, Hellerbrand C, Gäbele E: Deficiency of phosphatidylinositol 3-kinase (PI3K) aggravates inflammation and fibrosis in experimental NASH but protects against bile duct ligation induced liver fibrosis 


\section{VI.3. Danksagung}

Viele Leute haben direkt oder indirekt zum Gelingen dieser Arbeit beigetragen.

Mein Dank gilt deshalb:

- Herrn Prof. Dr. Claus Hellerbrand und Herrn PD Dr. Erwin Gäbele für die Überlassung und Betreuung des interessanten Themas und den gut ausgestatteten Arbeitsplatz, die Möglichkeit der Teilnahme an Kongressen und Fortbildungen, sowie die konstruktiven Diskussionen.

- Herrn Prof. Dr. Richard Warth, der mit der Übernahme der Betreuung an der NWF III diese Arbeit möglich machte, für das große Interesse am Fortgang der Arbeit, die angenehme Betreuung und vor allem für das in mich gesetzte Vertrauen.

- Frau PD Dr. Christa Büchler und ihrer AG für die Unterstützung bei der Untersuchung des Fettstoffwechsels.

- Herrn Dr. Thilo Spruss für seine Unterstützung bei tierexperimentellen Fragen.

- Frau Dipl. Ing. Sabine Kießling und Frau Diane Lochbaum ohne deren exzellente praktische Arbeit und große Unterstützung diese Arbeit nicht möglich gewesen wäre. Danke an die „AG EG“, es hat wirklich Spaß gemacht mit euch zu arbeiten !!!!

- Herrn Rudolph Jung für die große Unterstützung bei den immunohistochemischen Färbungen.

- Herrn Peter Karl und Herrn Herbert Gabler für die hervorragende Betreuung der Versuchstiere und die tolle Zusammenarbeit.

- Der „Lebergruppe“: Abdo Mahli, Barbara Czech, Michael Saugspier, Dr. Christoph Dorn, Daniela Valletta, Ruth Schewior, Monika Artinger, Birgitta Ott-Rötzer, Heidi Gschwendtner, Marina Fink, Margit Nützel 
und Kornelia Elser für die Unterstützung, die netten Gespräche und die vielen Kuchen und Plätzchen, die oft den Arbeitstag versüßt haben.

- Allen anderen Kollegen aus dem H1 für die freundliche Unterstützung bei allen Fragen und Problemen.

- Und last but not least: meinen Eltern: Meiner Mutter Marietta Dostert, die diese Arbeit durch alle Höhen und Tiefen begleitet hat und mir oft neuen Mut gegeben hat und meinem Vater Rainer Dostert, der leider meinen Lebensweg nicht weiter begleiten kann. 


\section{VI.4. Eidesstattliche Erklärung}

Ich erkläre hiermit an Eides statt, dass ich die vorliegende Arbeit ohne unzulässige Hilfe Dritter und ohne Benutzung anderer als der angegebenen Hilfsmittel angefertigt habe; die aus anderen Quellen direkt oder indirekt übernommenen Daten und Konzepte sind unter Angabe des Literaturzitats gekennzeichnet. Weitere Personen waren an der inhaltlich-materiellen Herstellung der vorliegenden Arbeit nicht beteiligt. Insbesondere habe ich hierfür nicht die entgeltliche Hilfe eines Promotionsberaters oder anderer Personen in Anspruch genommen. Niemand hat von mir weder unmittelbar noch mittelbar geldwerte Leistungen für Arbeiten erhalten, die im Zusammenhang mit dem Inhalt der vorgelegten Dissertation stehen.

Die Arbeit wurde bisher weder im In- noch im Ausland in gleicher oder ähnlicher Form einer anderen Prüfungsbehörde vorgelegt.

Regensburg, den 05.07.2011

Karin Dostert 